\title{
ARCHAEOZOOLOGY OF THE LATE ROMAN PERIOD SETTLEMENT AT VELKKÉ ZÁLUŽIE IN THE CONTEXT OF REGIONAL DATA ${ }^{1}$
}

\author{
Z O R A B I E L I C H O VÁ
}

\begin{abstract}
The research on Roman period archaeozoology is rarely discussed in Slovakia. So far, data suggest the great importance of cattle and pigs in the meaty diet and the focus on exploitation of caprines for the secondary products such as wool and milk. During the $3^{\text {rd }}$ and $4^{\text {th }}$ c. AD, an increasing role of pigs in the subsistence has been noted at Germanic sites in the vicinity of Bratislava. The analysis of a small bone assemblage recovered during the rescue excavation of the Late Roman period settlement at Vel'ké Zálužie (Nitra district), offered a similar results. The taxa representation as well as the sex and age assessment attested the leading role of cattle (33.6 \% by NISP) among the main meat suppliers. A balanced proportions of pig (15.3\%), caprines (13.4\%) and cervids (10\%) pointed out their minor, but not negligible importance of pork, lamb/mutton and venison in subsistence of the local Germanic peoples. Scarcely presented dog and horse bones provided no indices of butchery registered elsewhere in barbaric milieu (e.g. Vel'ký Meder). Bones of birds or fish were not found in the material either due to hand-recovery of analysed samples or restricted role within the diet. The calculated withers height of cattle $(113.7 \mathrm{~cm})$ and morphology of the horn-core showed that the local animals were small to medium sized with short horns. The simple tools made of worked animal bones/antlers offered the evidence on processing the pottery and/or leather or gaming. The partially preserved skeleton of a fawn red deer aged 3-4 months was found in one of the settlement pits.
\end{abstract}

Key words: Southwestern Slovakia, Roman period, animal husbandry, diet, fawn deer, bone artefacts.

\section{INTRODUCTION}

Although Roman period archaeozoology is rarely discussed in Slovakia, previous analyses provided some insight into the animal husbandry and subsistence of communities inhabiting the south-western region of the modern day Slovakia during the first four centuries AD. In this time the area evidenced the vanishing of Celtic and arrival of Germanic peoples, who settled here and from the $1^{\text {st }} \mathrm{c}$. onwards established tight political and commercial relations with the Romans through the neighbouring provinces (e.g. Kolnik 1971). Like in other Danubian regions, gradual cultural changes impacted the way of life and the economy of these local 'barbarian' tribes. The increased trade and mobility, documented also by remnants of the Roman-style architecture, the pottery and other forms of material culture of Roman origin (e.g. Beljak 2010; Elschek 2017; Kolník 2010; Varsik 2011; Varsik/Kolník 2013) provoke the question whether these are 'improvements' and how they influenced the people's daily-life including the main means of subsistence - farming. The archaeological excavations, usually not concentrating on the collection of ecofacts, provide little evidence on activities connected with food production. This was, according to the ancient writers, based mainly on keeping domestic livestock and hunting (e.g. Tacitus, Germánia 15,23) and was rarely affected by 'civilised' Rome. Although there are today variable ways to test this statement - like isotope analysis of human remains, and genetic studies of animal in addition to traditional archaeobotany and archaeozoology - in Slovakia such attempts are rare (Čejkal Hajnalová 2000; Fabiš 2003; Fabiš/Bielichová 2014; Hajnalová/Varsik 2010; Hajnalová et al. 2018; Hlavatá 2017; Krčová 2016).

Yet, the existing results of archaeobotany provide evidence on cultivation of fairly diverse cereal spectra including 'archaic' einkorn and emmer wheats as well as the 'new' free-threshing bread wheat and rye that are more typical for the Roman Provincial world (Hajnalová et al. 2018, 65). Though it is not clarified if the wide assortment of crops recorded in Germanic settlements from the south-western Slovakia is a result of surviving 'Celtic' tradition, the introduction of new staples from the Roman provinces, or a combination of the two (Hajnalovál Varsik 2010). Except for the Roman provincial sites (Hlavatá 2017) and a single site in the Roman period Barbaricum (Hajnalová et al. 2018) located in the southernmost limits of the Slovakian territory - and

\footnotetext{
1 This paper was written in the frame of two research projects: 'Process and regularities of the settlement development in mountain and foothill regions of Western Slovakia' (APVV-15-0491) and 'Celts, Romans and Germanic people. Rural settlements and the seats of nobility' (VEGA 1/0243/17).
} 


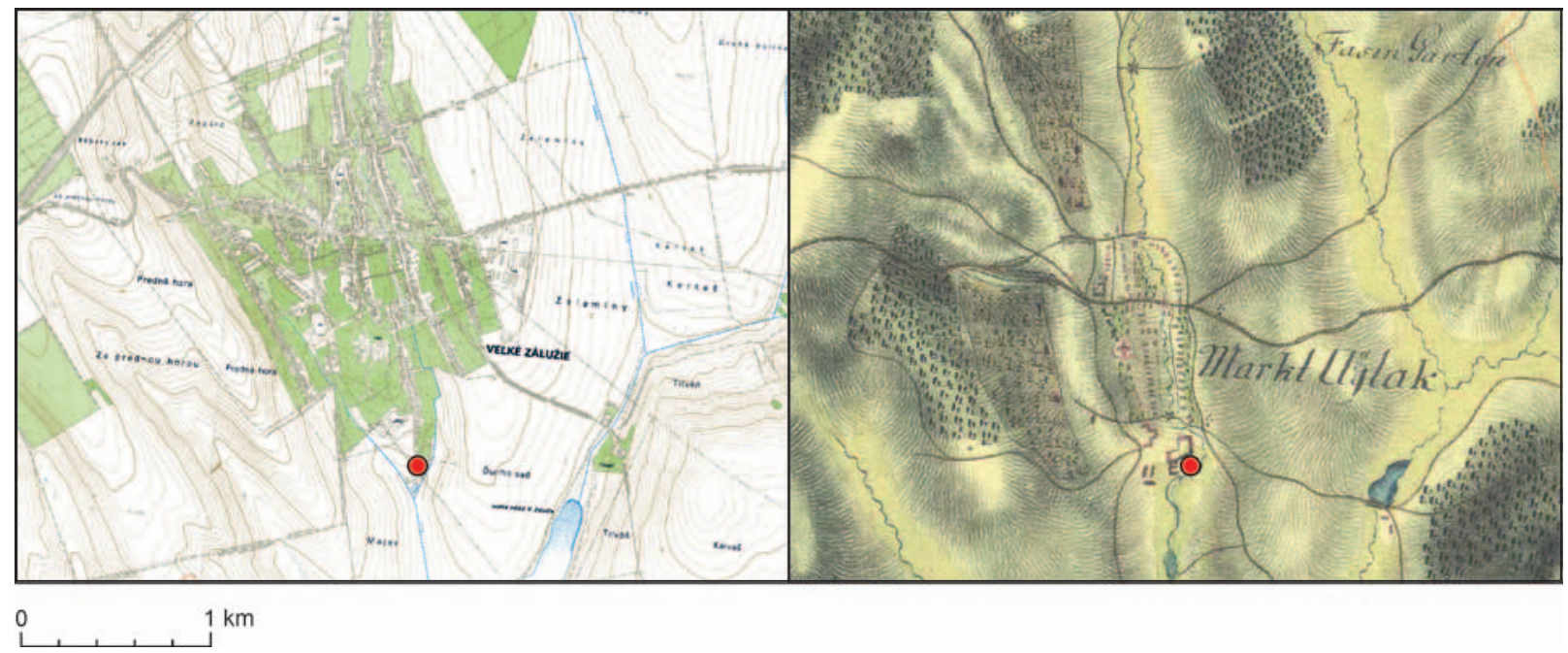

Fig. 1. Vel'ké Zálužie-Ďuriho sad. The geographic position of the site. The cut-out from recent and historic map.

immediately on or very close to the Limes, there were no exotic or (imported) luxurious plants identified. Archaeozoological research indicates that new species - such as cat, donkey and pigeon - first occur at Roman military or civilian sites and only later, if at all, at barbaric settlements (Ambros 1986a; Fabišl Bielichová 2014; Šefćáková 2011). It is clear that Germanic animal husbandry was, similarly to Celts in previous period, based on the keeping of domestic livestock with little additional supply from hunting and fishing. The NISP, WISP, ageing and butchery data suggest that the most significant animal was cattle, intensively exploited for its meat and labour. The MNI results indicate that on the majority of the settlements cattle and pigs were slaughtered in equal numbers. Meat consumption dominated by the most common domesticates was sometimes enriched by horses, chicken or goose. These animals were also being exploited for secondary products such as labour, transport, feathers, or eggs. The variability of local patterns in the exploitation of animals suggests, that there is a potential for further investigation of inter-site or regional differences connected with the economic and social status of inhabitants. For instance, the increase of pigs towards the $3^{\text {rd }}$ and $4^{\text {th }} \mathrm{c}$. AD, at least in the region of Bratislava (Šefčáková 2011) has been explained by an increase in the local population and/or the Romanization of the diet (Hajnalová et al. 2018, 66). Similar diachronic changes from La Tène to Late Roman period has been recorded for the body size of the main livestock species, cattle and sheep and were related to the Roman influence on local husbandry practices and/or imports of 'improved' breeds to the region (e.g. Bielichová 2017; Fabiš 2003; Fabǐ̌/Bielichová 2014).
This paper aims to contribute new information to the knowledge summarized above. It is based on the analysis of a bone assemblage retrieved during the excavation of a site at Vel'ké Zálužie-Ďuriho sad, that brought to light another Germanic settlement of the Nitra region and southwestern Slovakia. In spite of the rescue character of the excavation, it provided well preserved material with the known context and chronology $\left(3^{\text {rd }}-4^{\text {th }}\right.$ c. AD), the measurable elements and small collection of bone artefacts. Its complex analysis includes the study of taphonomy, species, skeletal elements, sex, age, butchery profiles, and animal morphology on an intra- as well as inter-site level. The comparative material from the southwestern Slovakia include yet unpublished results recorded by C. Ambros and M. Fabiš in the largest bone assemblages dated to the Roman period in Slovakia - Roman military camp at Iža and Germanic settlements in Cífer-Pác, Štúrovo and Vel'ký Meder. In order to evaluate the size of animals in a wider regional perspective, data from the Roman town Tác-Gorsium (Hungary) and Germanic settlements in Bernhardstahl, Bruckneudorf and Nickelsdorf (Lower Austria) will be discused.

\section{SITE INFORMATION}

The municipality of Vel'ké Zálužie is located in central western Slovakia, approximately $10 \mathrm{~km}$ south-west from Nitra and $80 \mathrm{~km}$ north of the Danube. It is situated within the contact zone of the southern border of Nitra Highlands and the adjacent Danubian Lowland that, with its fertile soils and favourable climatic conditions, has attracted settlers 

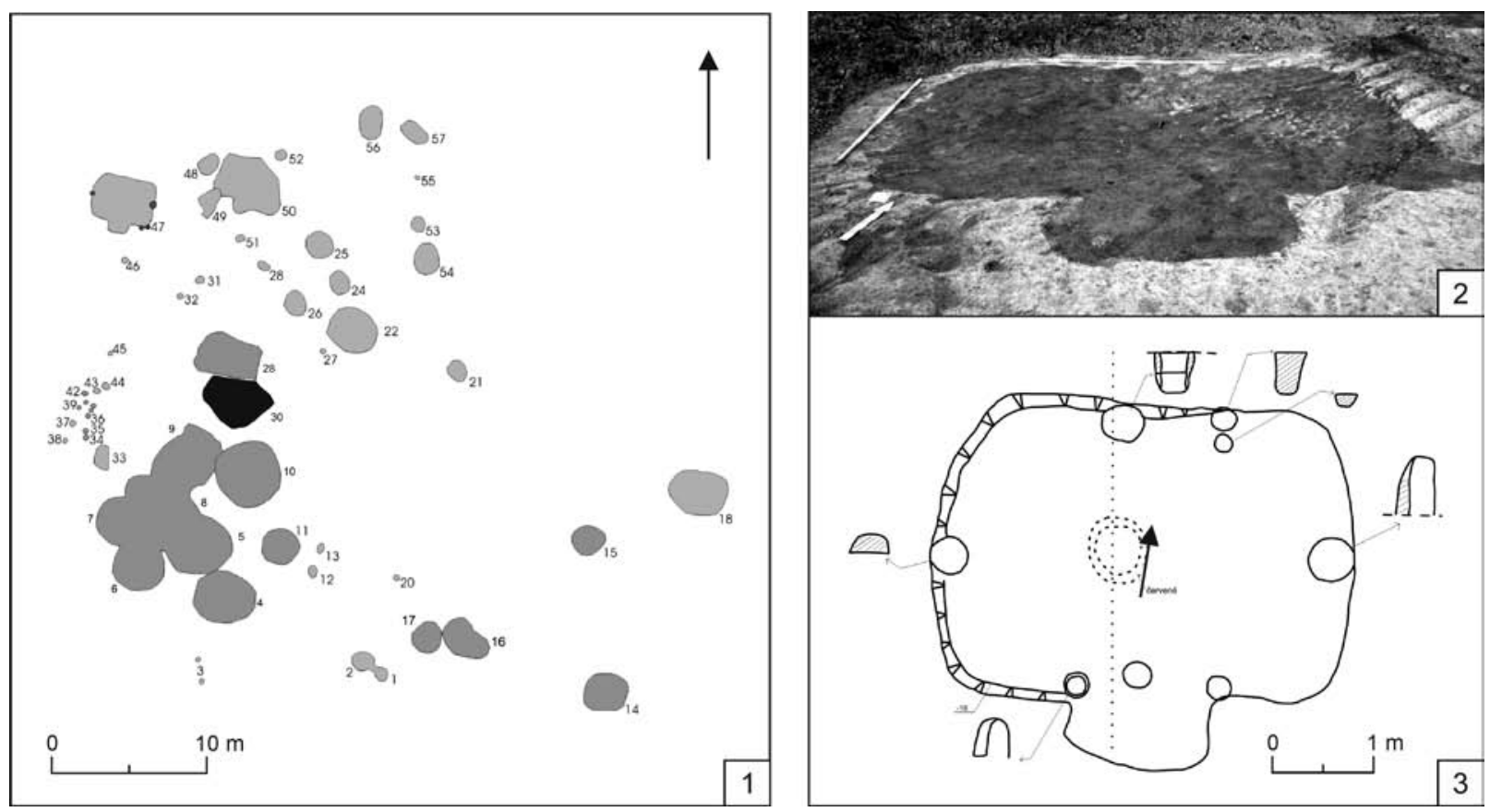

Fig. 2. Vel'ké Zálužie-Ďuriho sad. 1 - plan of the excavated area, Early Bronze Age feature shaded black; 2, 3-a sunken dwelling (feature 47). Photo and design by M. Bielich.

since prehistoric times. The first settlement dated to the Roman period has been documented in the location Na Horných Zalamínoch where potsherds dated to the $2^{\text {nd }}-3^{\text {rd }} c$. AD were collected during the field survey (Žaár/Poláková/Bielich 2009). The new Roman period settlement was discovered in winter 2007 at location Duriho sad (Kuzma/Bielich 2009). It is situated on the slightly elevated right bank terrace of the stream of Dolný kanál that meandered through the village in a north-south direction and further south joins the Nitra River (Fig. 1: 1, 2). In the past, the vegetation was dominated by autochtonuous alluvial forests. At present, the most common trees are oak which together with hornbeams and black locusts represent the main elements of the forest in the municipality (Bielich 2008).

The archaeological rescue operation was limited by a shortage of time, severe weather conditions, a high groundwater level and area planned for construction of a new building of the Immora Company (Žaár/Poláková/Bielich 2009). The sunken structures (58 in total), mostly represented by pits of various forms, were clearly identifiable within the yellow soil matrix by the contrasting dark-brown infill (Fig. 2: 1). A single dwelling with sunken floor (feature 47) and a six-post construction, had a rectangular ground plan and dimensions of $4.2 \times 3.6 \mathrm{~m}$, with the floor area of $13.5 \mathrm{~m}^{2}$. The entrance was situated in the southern, longer wall and remains of an open fireplace were found in the central part (Žaár) Poláková/Bielich 2009, 128; fig. 2: 2, 3). Other excavated structures included storage pits located east of the dwelling (features 22, 24-26 and 54). The post-holes (features 34-46) are considered to be remnants of unspecified above-earth structure(s), most possibly related to household or agricultural works (Žaár) Poláková/Bielich 2009, 129). Further to the south, the system of clay extraction pits was revealed (features 4-9). An outside oven was located (features 1-2) approximately $35 \mathrm{~m}$ south-east of the dwelling.

The preliminary artefactual and stratigraphic analysis suggested that, with a single exception ${ }^{2}$, all structures are datable to the Late Roman period (Eggers stage C1-C2; Kuzma/Bielich 2009, 161). The earliest occupation phase is denoted by the shards of terra sigillata of the late Antonine and Severus periods and the pottery design from features 47 and 5 (AD 170/178-200/210; Žaár/Poláková/Bielich 2009, 302). A distinct pottery shape and the presence of glazed mortars in features 6, 16 and 19 indicated that the late phase of occupation is related to the beginning of the $4^{\text {th }}$ C. AD (Žaár/Poláková/Bielich 2009, 314). Most of the finds in the remaining features, however, do not allow dating other than the Late Roman period. The register includes ceramic shards, clay weights, bone artefacts and animal remains. According to analysis of 840 pottery fragments (Žaár/Polákovál Bielich 2009, 302, fig. 6), 91 \% display attributes of

2 Structure 30 was dated to the Bronze Age Čaka culture (Žaár/Poláková/Bielich 2009). 
Germanic ware, $4 \%$ represent the import from the Roman provinces (Pannonia) and $5 \%$ is of prehistoric origin, an intrusion from older occupational strata. It has been assumed that the excavated area most probably represents the southern border of a large settlement area which had been abandoned peacefully (Žaár/Poláková/Bielich 2009, 312).

\section{MATERIAL AND METHODS}

\section{Archaeozoological material}

Analysis of the collected animal bone material was done shortly after the end of the fieldwork (Miklíková 2009). In total, 32 samples of 22 settlement features were hand collected (Tab. 1). It included moderately fragmented bone material with well preserved surfaces. In total 321 specimens were provided for the laboratory analysis of which $80 \%$ $(\mathrm{NISP}=238)$ were taxonomically identified. The remains are dominated by bones of large and medium sized mammals, as a consequence of size-related recovery bias. Due to lack of time, no archaeobotanical, malacological or microfaunal samples were taken. The infills of explored features were taken out by artificial layers ${ }^{3}$. According to the depth indicated, the uppermost strata (down to $35 \mathrm{~cm}$ ) provided minimum amount of bone finds ( $8 \%$ of the total). The rest originated (in similar portion) from the mid $(35-100 \mathrm{~cm})$ and lower strata $(100-150 \mathrm{~cm})$. In the case of sunken dwelling, specimens were collected from the floor. The comparison of the number of bones to that of pottery shards in particular showed negative correlation (Fig. 3). In contrast to shards, the largest number of bones were recovered from waste pit 5 and clay extraction pit 6 . Unspecified Roman period pits 10 and 15 were rather rich in bone and also yielded more pottery. Considerable numbers of bones and pottery were retrieved from the floor of a sunken hut.

Regarding the relative dating of bones, the relative chronological data based on the study of pottery and small finds, suggest their date to the $3^{\text {nd }}$ and $4^{\text {th }}$ c. $\mathrm{AD}$ (see above). No finer diachronic division of the analysed features was stated, so the assemblage is considered whole as being of the Late Roman period. With regard to the very low proportion of prehistoric pottery in the assemblage, we presume that the majority of animal bones was related to human activity that took place during the existence and/or last phases of the site's occupation. However, the formation processes were not studied in sufficient detail to support this assumption by
Tab. 1. Vel'ké Zálužie-Ďuriho sad. A list of analysed samples with the contextual information.

\begin{tabular}{|c|c|c|c|c|}
\hline 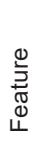 & $\begin{array}{l}\stackrel{ }{ㅇ ㅡ ㅁ ~} \\
\text { 든 } \\
\stackrel{ }{1}\end{array}$ & $\frac{\mathbb{d}}{\stackrel{\alpha}{<}}$ & 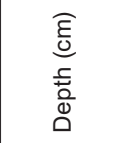 & $\begin{array}{l}\text { 으 } \\
\circ \\
\text { 어 } \\
\frac{1}{0} \\
\frac{1}{4}\end{array}$ \\
\hline 2 & Depression/pit & in front of the oven & $0-100$ & 9 \\
\hline 5 & Waste pit & cut & $30-60$ & 27 \\
\hline 5 & Waste pit & - & $0-130$ & 28 \\
\hline 6 & Clay exploitation pit & - & - & 12 \\
\hline 6 & Clay exploitation pit & cut & $0-110$ & 24 \\
\hline 6 & Clay exploitation pit & western part & $0-100$ & 29 \\
\hline 7 & Clay exploitation pit & cut & $0-120$ & 31 \\
\hline $7 \mathrm{~A}$ & Clay exploitation pit & - & $0-110$ & 30 \\
\hline 8 & Clay exploitation pit & cut 2 & $0-110$ & 22 \\
\hline 9 & Clay exploitation pit & cut & $0-110$ & 23 \\
\hline 9 & Clay exploitation pit & - & $0-110$ & 32 \\
\hline 10 & Undetermined pit & - & $0-15$ & 1 \\
\hline 10 & Undetermined pit & - & $0-100$ & 19 \\
\hline 11 & Undetermined pit & - & $0-100$ & 4 \\
\hline 14 & Undetermined pit & - & $0-35$ & 18 \\
\hline 14 & Undetermined pit & southeastern part & - & 25 \\
\hline 15 & Undetermined pit & - & $0-50$ & 17 \\
\hline 18 & Undetermined pit & - & - & 13 \\
\hline 19 & Undetermined pit & - & $0-65$ & 16 \\
\hline 22 & Storage pit & - & $0-120$ & 7 \\
\hline 23 & Undetermined pit & cut between 17, 18, 19 & - & 5 \\
\hline 24 & Storage pit & - & $0-150$ & 8 \\
\hline 30 & Undetermined pit & - & $0-70$ & 21 \\
\hline 33 & Undetermined pit & - & $0-40$ & 2 \\
\hline 47 & Sunken house & - & - & 10 \\
\hline 47 & Sunken house & floor & - & 26 \\
\hline 50 & Waste pit? & - & $0-120$ & 6 \\
\hline 54 & Storage/waste pit? & - & $0-70$ & 15 \\
\hline 58 & Undetermined pit & - & $0-70$ & 3 \\
\hline 58 & Undetermined pit & - & $0-70$ & 11 \\
\hline 58 & Undetermined pit & - & $0-70$ & 14 \\
\hline 58 & Undetermined pit & - & $120-140$ & 20 \\
\hline
\end{tabular}

field observations. Moreover, as we deal with multiperiod occupation (the Bronze Age feature 30), the possibility of intrusion from older periods cannot be ruled out. There are no absolute chronological data available at the moment.

\section{Research methods}

The analysis consisted of the identification of taxa and skeletal elements, assessment of sex and age-at-death of animals, taking biometric data, and

\footnotetext{
3 M. Bielich, pers. comm. 2018.
} 


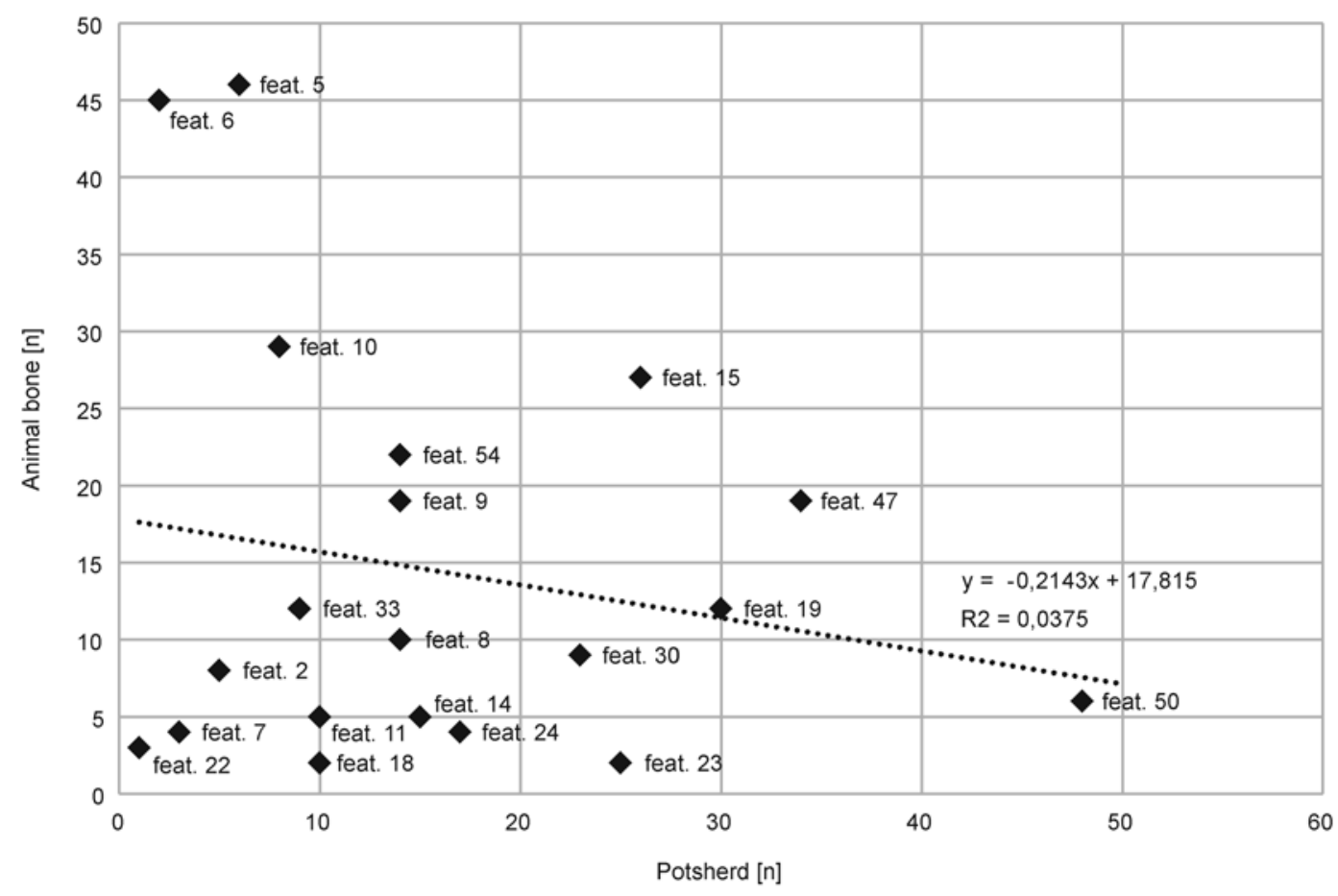

Fig. 3. Vel'ké Zálužie-Ďuriho sad. The number of potsherds and bone fragments from the studied settlement features.

recording modifications such as gnawing, burning and butchery. The primary analysis included also the identification of osteopathologies and bone working. All investigations were carried out on the basis of visual comparative using the reference collection housed in the archaeozoological laboratory at the Institute of Archaeology in Nitra and the relevant literature (e.g. Hrudka/Popesko/Komárek 1962; Kolda 1936; Komárek/Štěrba/Fejfar 2001; Schmid 1972). The anatomical nomenclature was adopted from the Nomina Anatomica Veterinaria authorized by I.C.V.G.A.N. (Popesko et al. 1974). The naming of zoological taxa followed the propositions of A. Gentry, J. Clutton-Brock and C. P. Groves (2004). The identification was made on a species (e.g. Equus caballus), genus (e.g. Equus sp.), family (e.g. Equidae) or class level (e.g. Mammalia). It was limited by the preservation of bones and available reference collection. The problems occurred while distinguishing sheep and goat bones (Ovis/Capra), domestic and wild forms (e.g. pigs and wild boar) and identifying members of Bovinae subfamily (cattle, aurochs and bison). Taxonomically unidentified specimens were classified according to the size of the animal they might represent (e.g. large mammal).

In domestic ruminants sex has been assessed on the basis of horn-core shape/size, the relative width of metapodials (e.g. Luff 1994; Novotný 1966; Schmid 1972) and pelvic bone formation. In pigs, the sex has been determined according to canine morphology, in deers it was done on the basis of antlers. Criteria used in age assessment were long bone epiphyseal fusion and the eruption/abrasion of teeth (e.g. Habermehl 1975; Reitz/Wing 1999, 76, tab. 3.5; Silver 1969). The mandibular teeth were sorted into categories suggested by L. Peške $(1994,308,309)$. The age and season of death of red deer were assessed according to K.-H. Habermehl $(1985,25-27)$ and V. Komárek, O. Štěrba and O. Fejfar (2001, 80, 426).

The description of butchery marks followed the categories set in the archaeozoological database (see below) and reconsidered through works of $D$. Rixson (1988) and K. Seetah (2006a; 2007). Burning, gnawing, and bone artefacts were evaluated according to $E$. $J$. Reitz and E. S. Wing (1999, 133-135) and R. L. Lyman (1994, 205-219, 384-392). The palaeopathological alterations were classified after J.R. Baker and D. R. Brothwell (1980) and L. Bartosiewicz/W. Van Neer/ A. Lentacker (1997). Measurements were taken after A. von den Driesch (1976). The withers height of cattle was calculated using coefficients established by J. Matolcsi (1970, 113, tab. 14) and V. I. Calkin (1960; in Matolcsi 1970, 113, tab. 14). The total live weight of cattle has been calculated on the basis of method proposed by J.-D. Vigne (1991). The evaluation of skeletal elements followed the 'qualitative' classification suggested by H.-P. Uerpmann (1973) and the weight difference method (Kunst 2002). 
All primary and secondary data are recorded in the database established for archiving and evaluation of faunal remains from archaeological sites ${ }^{4}$. For basic quantification the number of identifiable specimens (NISP) and weight of identifiable specimens (WISP) were used. These mean simple counts and weights of each bone, antler, or teeth specimen. Glued fragments were counted and weighed together. The minute undetermined bone fragments from the same context (sample) were counted and weighed as 1 . The minimum number of individuals MNI was estimated separately for features and for the total assemblage (Kysely 2004, 286). Bones were weighted on a Kern laboratory scale with the accuracy of $0.1 \mathrm{~g}$. The measurements were taken with In size digital callipers with an accuracy of $0.1 \mathrm{~mm}$. The specimens were examined using an unaided eye or simple hand lenses, but some butchery marks and surfaces of bone artefacts have been investigated using a Zeiss Discovery V.12 stereo-microscope (5-50x). Photographs of selected cases were taken and edited by the author using a Sony Cybershot DSC (7.2 MP) digital camera, a Zeiss Discovery V.12 stereo-microscope and Keyence VHX-700F 3D digital microscope. Bone artefacts were drawn by Beata Arvaiová from the Institute of Archaeology of the SAS in Nitra.

\section{Regional comparative data}

In the course of past centuries several papers and research reports offered new data on animal bones found at the Roman period sites in Slovakia. So far available analyses provide published and unpublished results of 22 investigated settlements (Fig. 4; Tab. 2). The Roman-Provincial milieu is represented by the military camps/forts in Bratislava-Rusovce, on the right bank of the Danube, being an integral part of the Roman Pannonia (ancient Gerulata; Kraskovská 1990; Kuzmová/Rajtár 1996) and in IžaLeányvár on the left bank of the Danube, in the territory of the Barbaricum, and functioning as a bridgehead of Brigetio (ancient Celemantia - Hajnalovál Rajtár 2009; Kuzmová/Rajtár 1986a; 1986b; Rajtár 1992). With regard to the Roman-barbaric culture, the Germanic settlements in Cífer Pác (Kolník 1975; Varsik/Kolník, forthcoming), Vel'ký Meder (Hajnalovál Varsik 2010; 2015; Varsik 2004), Nitra-Chrenová (Březinová et al. 2003), Nitra-Párovské háje (Pieta 1993; Pieta/Ruttkay 1997), Most pri Bratislave (Turčan 1995),
Bohdanovce nad Trnavou (Turčan 1995; 1996), the eastern forelands of Bratislava (Varsik 2003b; 2011), Malá nad Hronom (Ožd’áni 1984), Trnava (Pavúk 1977), Biely Kostol (Bartík/Farkaš/Turčan 1995; Bartík et al. 1995), Bohdanovce nad Trnavou (Turčan 1995; 1996), Jakubov (Varsik 2003c), Štúrovo (Beljak 2008; 2010; Kolník 1962) and Želiezovce (Novotný 1984) have all been studied archaeozoologically.

The resulting data, diverse from the social, chronological, and cultural point of view, hide multiple archaeozoological problems that limit their interpretative value. One of these problems is the insufficient number of identifiable bone specimens. Very few assemblages analysed to date provide more than 500 identifiable specimens per site that used to be considered a representative sample. ${ }^{5}$ This condition was fulfilled only at Bratislava-Trnávka, Cífer-Pác, Nitra-Chrenová, Štúrovo, Vel'ký Meder and Iža. In addition, the results of analyses have been published for just three of them (Fabis 2003; Fabiš/Bielichová 2014; Šefčáková 2011). The largest and most representative assemblages from Cífer-Pác and Iža have not yet been published and data exist only in the form of manuscripts or research reports. Other settlements listed in this paper (Tab. 2), such as Jakubov, Ivánka pri Dunaji, Bohdanovce nad Trnavou, provided very small numbers of bones for the study (NISP less than 50), so their information value is negligible in terms of relative proportion of taxa or skeletal elements. The second major problem with regard to the dataset from Slovakia is the sampling and recovery methods of ecofacts in general. Except for the recent case of a settlement pit from Hurbanovo, all remains were retrieved by hand, without systematic sieving or flotation.

Therefore fish, birds or molluscs are rarely present and their roles within the subsistence or economy cannot be appraised. Among the documentary sources, there is one special paper devoted to archaeoichthyology and the Roman period (Hensel 2004).

The third major problem is rooted in the quality and complexity of data and/or analyses. In many cases, the literature provides only simple summary tables of taxa and/or skeletal element representation or vice versa, simple listings of taxa and skeletal elements per site/feature, without providing the quantification tables. This situation precludes the evaluation of records within the spatial, chronological and archaeological context. In connection to this, another big problem is caused by missing

\footnotetext{
4 The application of MS Access has been established by the archaeozoologist R. Kyselý (Institute of Archaeology of the Czech Academy of Sciences in Prague) and is currently used as a standard recording procedure in the Institute of Archaeology of the Slovak Academy of Sciences in Nitra.

5 For comment on sample size and inter-site comparisons see S. Bökönyi $(1974,18)$.
} 


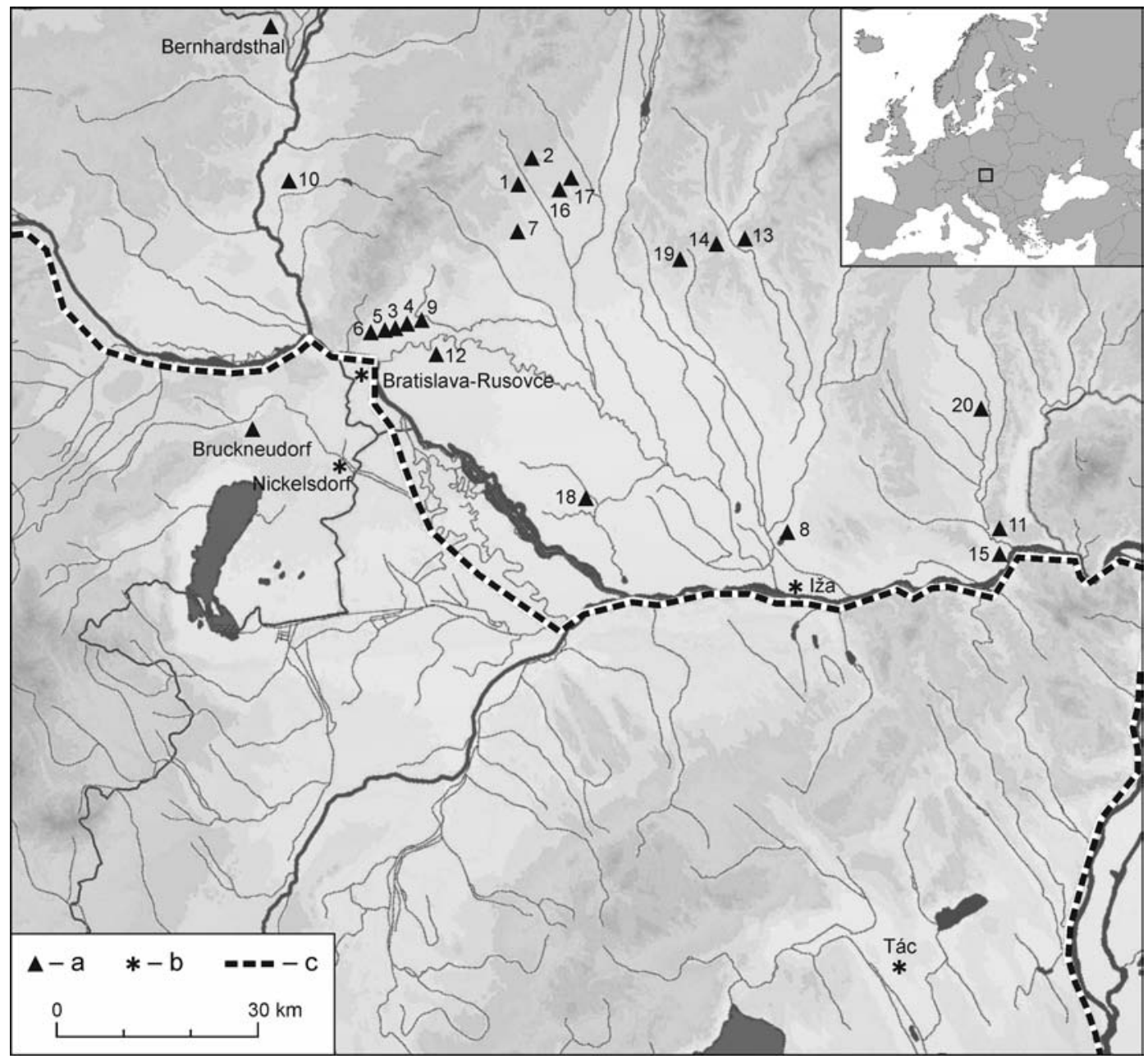

Fig. 4. The geographic position of the Roman period sites from southwestern Slovakia and adjacent areas discussed in the paper. For the site codes see Tab. 2. Legend: $a$ - Germanic; b-Roman; c-Roman frontiers.

or unpublished raw data including sex, age and osteometrics which exclude interpretations on local animal husbandry regimes and palaeoeconomy. With a few exceptions (e.g. Fabiš 2003; Šefčáková 2011), Slovakia has no representative and complex analyses published till the present day hampering inter-site comparisons.

In order to reveal at least preliminary regional patterns, sites providing at least 200 NISP will be included in the comparative evaluation of new data from Vel'ké Zálužie. Other aspects of the material such as butchery, age, sex, modifications, morphology or pathology will be discussed mainly in terms of presence/absence. The relative quantitative data will be compared only if substantial numbers of finds are available. Due to the scarcity of data from southwestern Slovakia, the studied site will be reviewed with regard to particular finds (or aspects) of large assemblages from the Lower Austria and Hungary (Fig. 4). The Germanic settlement in Bernhardstahl is situated at Thaya (Dyje) River approximately $60 \mathrm{~km}$ north of the Roman Limes of the Danube and dates to the $2^{\text {nd }}$ and $3^{\text {rd }} \mathrm{c}$. AD (Riedel 1996). The analysis of more than 14 thousand bone specimens indicated the local economy based on domestic animals, with cattle comprising nearly $70 \%$ of NISP. The Germanic settlement within the Roman sphere of control in Bruckneudorf lies $40 \mathrm{~km}$ southeast from Vienna and dates to the $1^{\text {st }}$ and $2^{\text {nd }} \mathrm{c}$. AD (Pucher 2016). Almost half of 11 thousand specimens belonged to cattle, while small ruminants, pigs and equids each contributed $14 \%$ to the NISP. Poultry as well as game were of minor importance in the diet. The profound morphometric examination showed the co-existence of at least two types of cattle with different modes of exploitation. A mixed-purpose use was typical for domestic cattle, whereas Roman cattle was not raised in the settlement itself but was gathered and delivered only for the purpose of meat supply (Pucher 2016, 317). The Roman villa at Nickelsdorf is situated $60 \mathrm{~km}$ away from Vienna, eastern Austria and dates from $2^{\text {nd }}$ to $3^{\text {rd }} \mathrm{c}$. AD (Riedel 2004). 


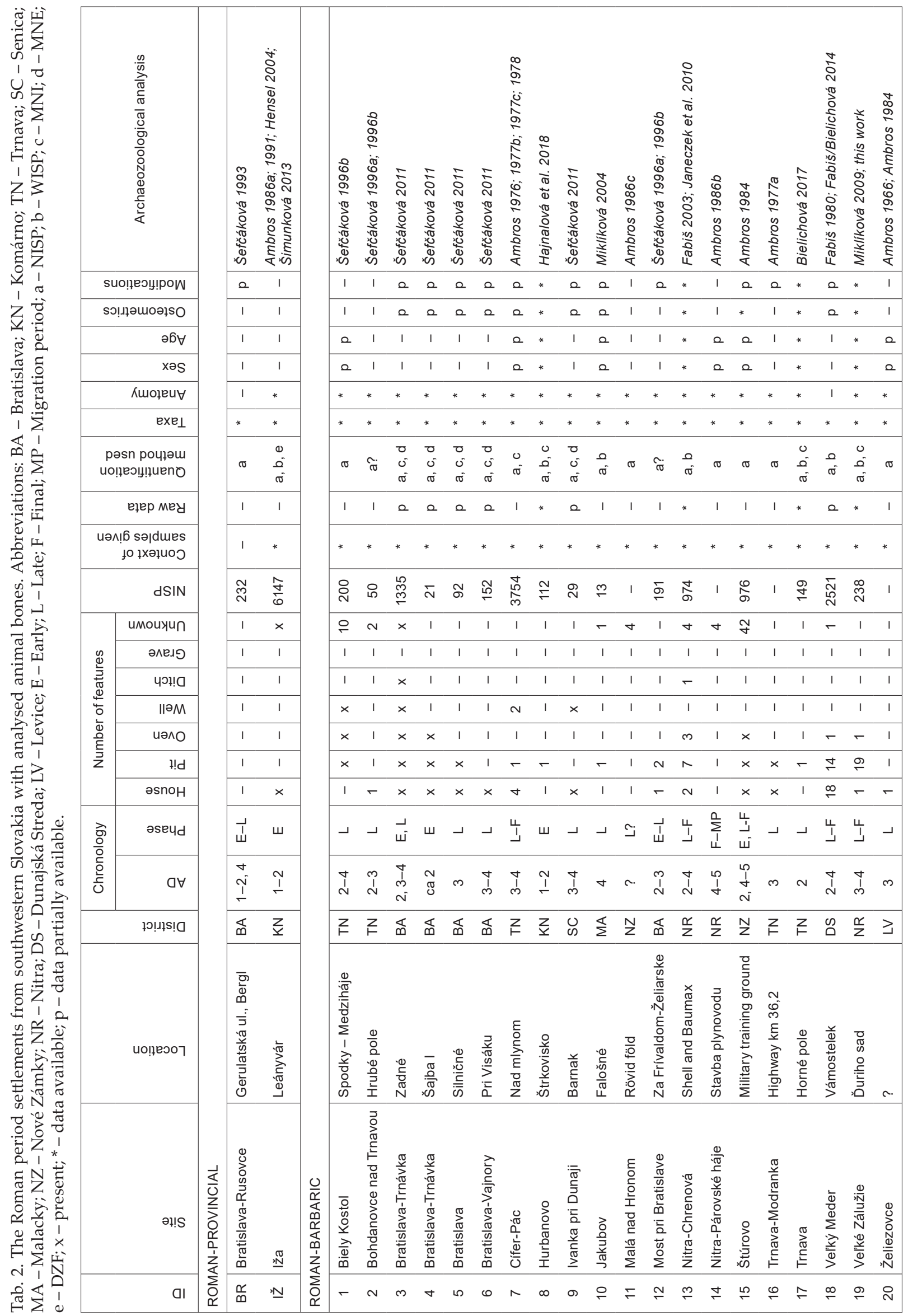


Tab. 3. Vel'ké Zálužie-Ďuriho sad. The representation of butchery marks in identified taxa.

\begin{tabular}{|l|c|c|c|c|c|c|c|c|}
\hline \multicolumn{1}{|c|}{ Butchery mark } & Cattle & Pig & Sheep & Caprines & Red deer & $\begin{array}{c}\text { Caprines/ } \\
\text { roe deer }\end{array}$ & $\begin{array}{c}\text { Large } \\
\text { mammal }\end{array}$ & NISP \\
\hline Shallow cut & 8 & - & 2 & 1 & - & - & - & 11 \\
Moderate cut & 6 & 2 & 1 & 4 & - & - & 1 & 14 \\
Deep cut & 2 & 1 & - & - & - & - & 2 & 5 \\
Cut/chop & 1 & - & - & - & 1 & - & - & 2 \\
Chopped off & 2 & 1 & 1 & - & - & - & - & 4 \\
Chopped through & 6 & 1 & - & - & - & - & - & 7 \\
Choppped through by heavy implement & 2 & - & - & - & - & - & - & 2 \\
Chopped through? & 4 & - & - & - & - & 1 & - & 5 \\
Probably smashed & 3 & - & - & 1 & 1 & - & - & 5 \\
\hline Total & 34 & 5 & 4 & 6 & 2 & 1 & 3 & 55 \\
\hline
\end{tabular}

It lies only few kilometres from Carnuntum, the capital of the Roman province of Upper Pannonia. The analysis of more than six thousand specimens revealed the importance of domestic livestock in the economy, with the dominance of cattle (ca 33\% of NISP) and considerable portion of horse (20\%) and dogs (13.5\%). The morphometric study of two well preserved skeletons of oxen revealed their affiliation to the Italic 'improved' type of cattle (Pucher 2006). The Roman town of Tác-Gorsium was an important military, commercial and religious centre of Upper Pannonia province situated $80 \mathrm{~km}$ south of the Roman Limes of the Danube. The long-term excavations yielded more than 50 thousand identified bone specimens that are crucial for understanding animal-human relationships within the urban provincial setting. The material dates back to the $1^{\text {st }}-4^{\text {th }} \mathrm{c}$. AD and suggested persisting importance of cattle together with caprine and pig. The co-existence of two cattle and three sheep 'breeds' together with new species such as donkey, cat, goose, pigeon and perhaps equid hybrids attested Roman influence on the local husbandry practices (Bökönyi 1984).

\section{RESULTS AND DISCUSSION}

\section{Bone modifications}

Modified bone elements are important indicators of the taphonomic history of archaeozoological assemblages (e.g. Lyman 1994; Reitz/Wing 1999). This study focuses on those characterizing past human activities and the natural environment of the site. Bones in the mixed settlement refuse result from similar activities including killing, skinning and butchering of animals, cooking/curing of meat, consumption including gnawing and digestion by humans, working of bone/antler, and discard followed by animal gnawing, trampling, fragmentation, weathering, deposition and even redeposition (Reitz/Wing 1999, 124-139). Each specimen may have been multiply modified - at first during carcass partitioning, then gnawing by carnivores and pigs, and again during trampling and weathering. Recognizing causalities is thus a difficult task. The studied material, however, provided some good examples of taphonomic factors that illustrate the following stages of carcass processing ${ }^{6}$ : primary butchery represented by slaughter and initial dressing off including killing, blood removal, skinning, evisceration and removal of the head and feet (1), secondary butchery represented by the gross dismemberment of the carcass at joints/main muscle attachment sites aimed at removing major cuts/portions (2), tertiary butchery represented by reduction of chops into smaller portions for cooking purposes (3), marrow extraction (4) and bone working (5). Butchery and gnawing marks were recorded frequently on the bones, while traces of bone working noted only sporadically.

\section{Butchery marks}

Butchered bones were registered in nearly all settlement features recovered, but in relatively small numbers (Fig. 5). They were most frequent were in cattle (62\% of total NISP), where they occurred with a relative frequency of $31.5 \%$ (of total NISP of cattle; Tab. 3). Some marks of butchery have been registered in sheep/goats (18.2\% of total; $23.3 \%$ of sheep/goats), pigs ( $9.1 \%$ of total; $10.2 \%$ of pigs) and deer (3.6\% of total; $6.3 \%$ of deer). A higher occurrence of butchery in cattle is related to significantly

\footnotetext{
6 After D. Rixson 1988, 49.
} 


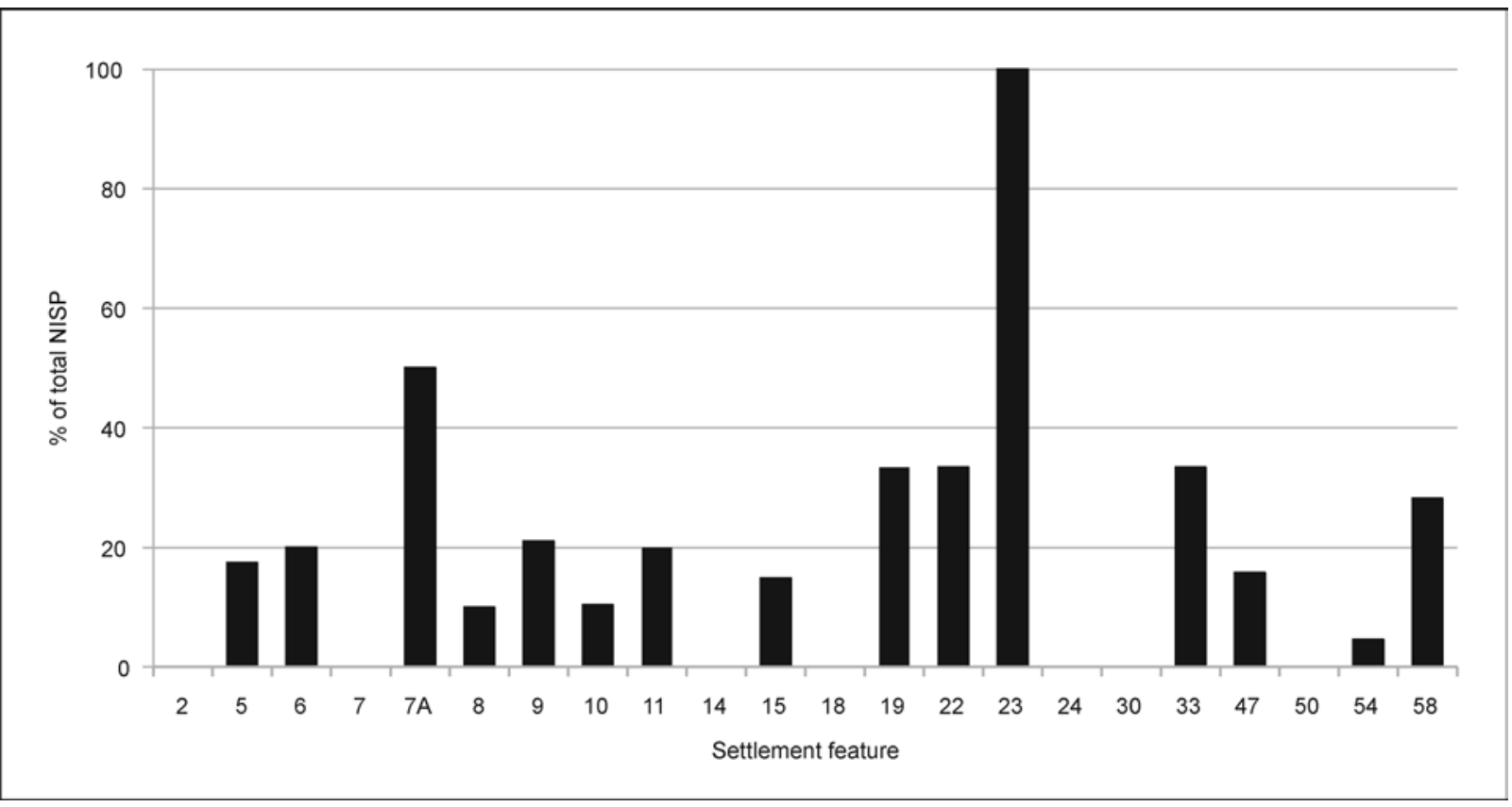

Fig. 5. Vel'ké Zálužie-Ďuriho sad. The incidence of butchered bones in the studied features.

larger carcass size as well as culinary practices. There were no butchery marks observed on horse and dog bones which supports the presumed exploitation of these two species for labour, transport or companion rather than meat.

Traditional ways of slaughtering animals were stable and characteristic in time and region. Osteological evidence of killing animals, however, seems rare (Reitz/Wing 1999, 127). The farmers usually cut the throat with a knife, which brings the fast and painless death to the animal. If the cut is deep enough, marks occur on the ventral or dorsal plane of the first cervical vertebra and/or in the occipital region. Such a find occurred in the studied assemblage: a sheep first cervical vertebra (atlas) bears a few short and shallow, transversally oriented cut marks on the ventral arch (Fig. 6:1) which clearly documents the use of a sharp, metal implement (knife?) from the ventral (lower) plane of the body. Another example of this type is seen on the second cervical vertebra (Epistropheus) of a deer. In this case, depth and direction of marks are different, indicating the post-mortem decapitation of the carcass (Bartosiewicz/Vaughan/Tóth 2013, 303). The bone had been multiply chopped through the vertebral tooth (dens epistrophei) and the force was clearly directed from the dorsal (upper) plane of the body (Fig. 6: 2).

Although skinning may not always leave a trace, sometimes marks occur on elements where the skin is tightly attached to the bone and uncovered with flesh (Reitz/Wing 1999, 128). Transversally or obliquely oriented cut marks of light to moderate intensity used to be located across the head, mandible, distal limb bones and tail skeleton (e.g. Lapham 2005; Val/Mallye 2011).

Primary butchery also includes evisceration during which edible internal organs and mesenteric fat of the thorax and abdomen are removed. Marks of such activities are almost invisible but may sometimes be found on the medio-ventral (inside) part of the ribs or vertebral corpus (Chaix/Méniel 1996, 47). In this sense, none of recorded cut marks can be ascertained as clear skinning and evisceration mark. However, the extraction of brain may be suspected on the basis of highly fragmented cattle skull bones with clear chop marks (Fig. 6: 9). Most probably, cattle and sheep horn-cores were cut-off during primary butchery (Fig. 6: 3). The following stages of butchery (see above) are well-documented by characteristic marks of cuts, chops, hacks, slicing, point/blade insertions or knicks. ${ }^{7}$ A case of deliberate disarticulation was recorded on a cattle mandible, in which the tip of the coronoid process had been chopped off in order to separate the jaw from the skull. In the same specimen wide cut marks are visible across the vertical ramus, perhaps as remnants of cheek meat removal (Fig. 6: 4). Usually knife cut marks at the points of muscle insertions are indicative of the removal of meat i.e. groups of muscles and further sectioning of the carcass parts.

\footnotetext{
7 For explanation and detailed description of butchery marks see work of K. Seetah (2006a; 2007).
} 


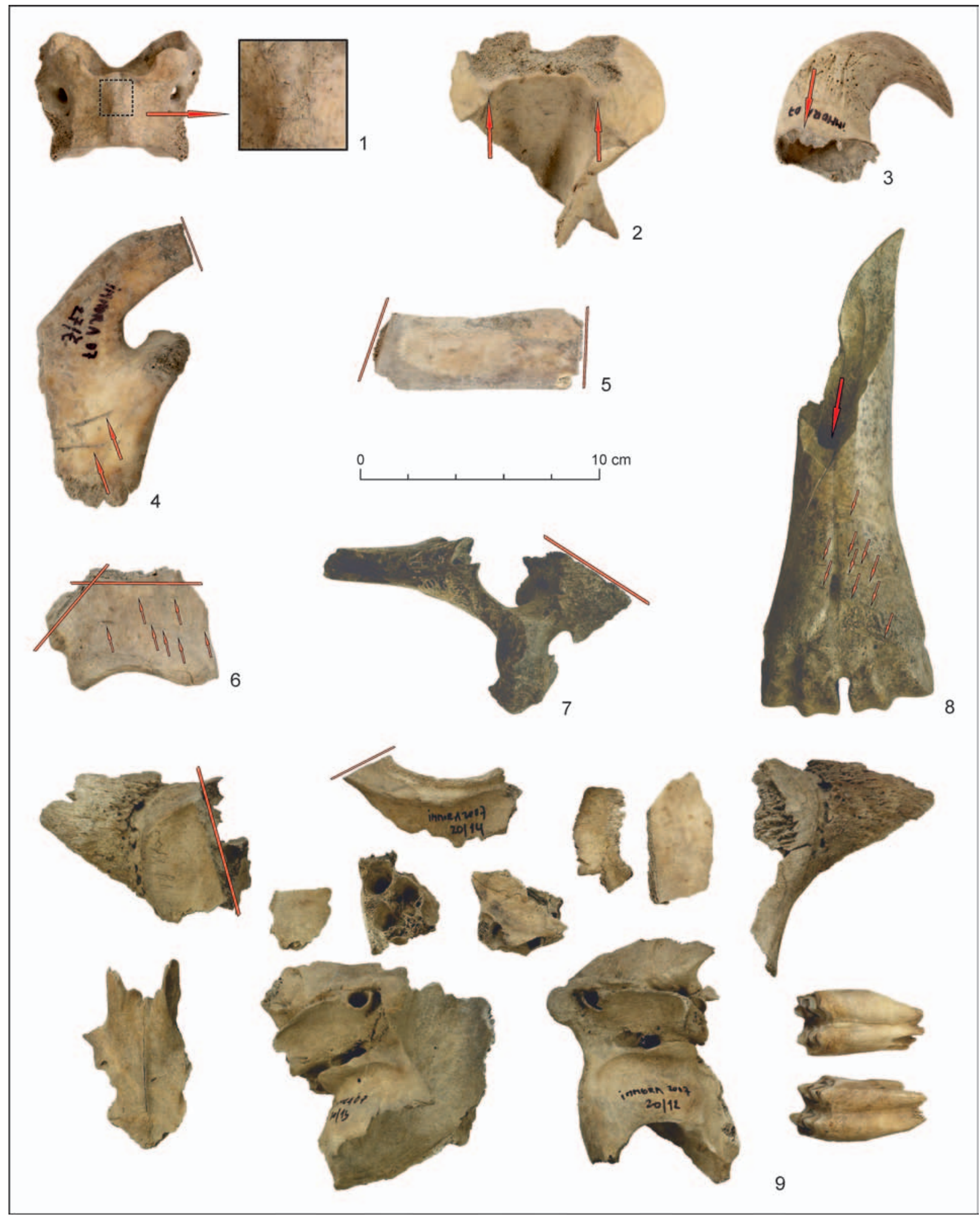

Fig. 6. Vel'ké Zálužie-Ďuriho sad. A selection of butchery marks. 1 - multiple fine cuts (detail in black square) on the ventral arch of the first cervical vertebra of a sheep, ventral view; 2 - cut/chop through dens vertebralis of the second cervical vertebra of a red deer, dorsal view; 3 - cut/chop through the base of a sheep horn-core, view from above; 4 - cattle mandible with chopped off coronoid process and deeper cuts on ramus mandibulae, lateral view; 5 - cattle rib chopped off on both ends, anterior view; 6 - cattle scapula with chopping through collum scapulae and tuberositas supraglenoidalis and a series of fine short cuts, lateral view; 7 -chopping through the cattle (?) thoracic vertebral body close to its medial axis, upper view; 8 - partly preserved cattle metatarsal bone showing spiral fracture, perhaps as a consequence of intentional opening of the shaft, dorsal view; 9 - cattle skull fragments with traces of chopping. 


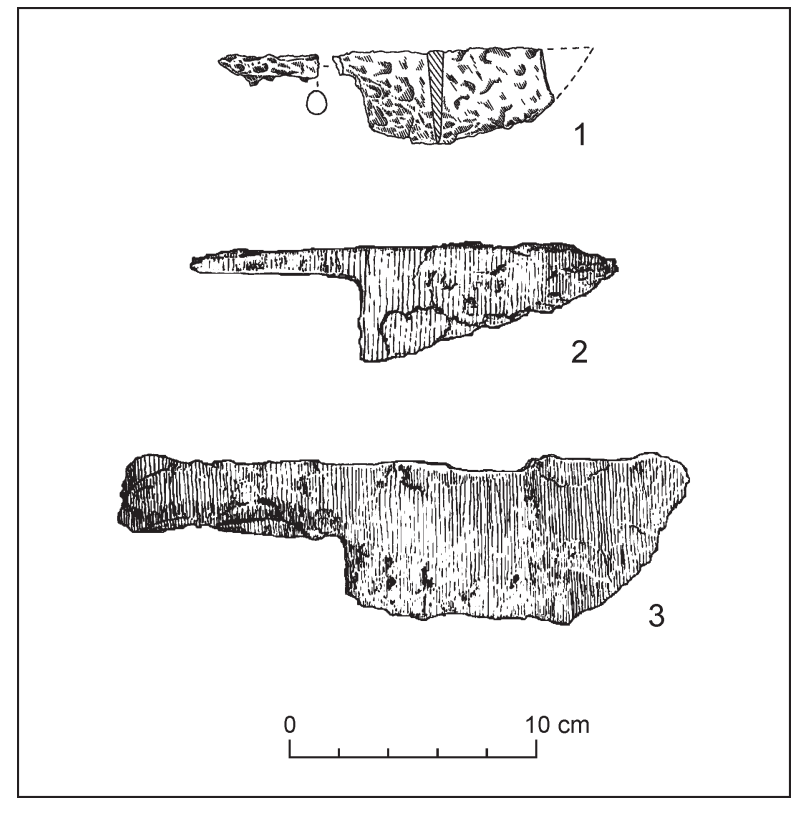

Fig. 7. The large blade finds from the Roman period sites. 1 - a large knife from Germanic residence in Cífer-Pác, reg. nr. 112/78, not scaled (approximate length $15.4 \mathrm{~cm}$ ); 2 - Roman large knife with tapered tang (after Seetah 2006a, 42, fig. 3: 2b); 3 - Roman cleaver, with full tang (after Seetah 2006a, 42, fig. 3: 2a).

Traces of filleting were not noted. The pot-sizing or breaking of bones in order to exploit marrow and prepare portions of vessel size or a particular type of a meal includes the fracturing of bones with a cleaver (Fig. 6: 7) and chopping into regular sized units (Fig. 6: 5). As for kitchen equipment, the use of metal implements with a fine blade, most probably of small to medium sized knives, seems to have been most probable. Cuts displaying shallow and sharply grooved V cross-sections support this hypothesis. However, deeper cuts with wider cross-section also occurred, indicative of heavier implements with larger blades. Some of the large and robust skeletal elements or cancellous bones were smoothly chopped through (Fig. 6: 6, 7) indicating the impact of such larger and heavier blades. Small-sized knives, with the blade up to only $10 \mathrm{~cm}$ in length, belong to the most common finds at sites in the adjacent Barbaricum in southwestern Slovakia (e.g. Beljak 2008, 76, fig. 13: 3; Varsik 2011, 121, 122, fig. 61: 7-12; Kolník/Varsik/Vladár 2007, 178, tab. 26: 7, 8). An example of a large knife or a 'cleaver', resembling the Romano-British large blades (cf. Seetah 2006a, 41, fig. 7: 2, 3), has been reported from the Germanic residence in Cífer-Pác (Fig. 7: 1). ${ }^{8}$ Ano- ther metal knife with larger and longer blade was also retrieved at the recently explored settlement in Beladice (Ruttkayová/Ruttkay 2015, 51, fig. 68). The 'butchers' of the Roman period and the Middle Ages used 'large blades' for slicing the meat after its removal from the bone (for more see Seetah 2006a; $2006 b$; 2007). Such blades represent the most used implement in the butchery trade, however, they are the least likely to leave a mark on the bone itself. This is in contrast to the cleavers or small knives that leave chop and cut marks during portioning the carcass into more manageable or saleable joints and for deboning these joints (Seetah 2007, 6). Nevertheless, also large blades may had been used for chopping.

The frequency of bones chopped by 'large blades' and/or cleaver/axe in the studied assemblage (ca $24 \%$ of butchered bones) is comparable with the butchery pattern and intensity recorded in the small assemblage from the Germanic settlement at Beluša, located in northwestern Slovakia (Miklíková 2003a). Here, a high incidence and wide variety of chopped bones were registered. Interestingly, at both sites the use of heavy metal tools with large blades (cleaver/axe?) was indicated by the placement of cuts (in the articular regions of long bones) and implement signature (smooth entry and fractured points of a cut plane). On the other hand, other Germanic assemblages from the region, if analysed for butchery marks, did not include such heavily butchered bones (e.g. Trnava-Horné Pole-Bielichová 2017). There the patterns mostly include shallow or fine cut marks and the smashing of bones for marrow, similarly to prehistoric assemblages. Previous research at Roman period sites revealed that large mammal bones with clear chops by large blades, filleting and scoop marks result from organized meat supply and processing of large amounts of meat typical of Roman-provincial sites (e.g. Choyke 2003; Lyublyanovics 2010; Seetah 2006b). Despite more common 'prehistoric butchery manners' including the smashing of bones, people from Vel'ké Zálužie frequently used large blade implements. This may be related to a higher consumption and demands for meat or local culinary practices.

\section{Burning}

Cooked meat is usually boiled, baked, stewed or roasted. When meat is roasted, bone parts most thinly covered by flesh will be exposed to the flame and may burn (Reitz/Wing 1999, 131). Burning, however,

\footnotetext{
8 I am indebted to V. Varsik from the Institute of Archaeology of SAS in Nitra for the information on unpublished artefacts from the excavation carried out by T. Kolník in Cífer-Pác.

9 They are considered to represent dual-purpose implements (see Seetah 2006a, 41, 42).
} 


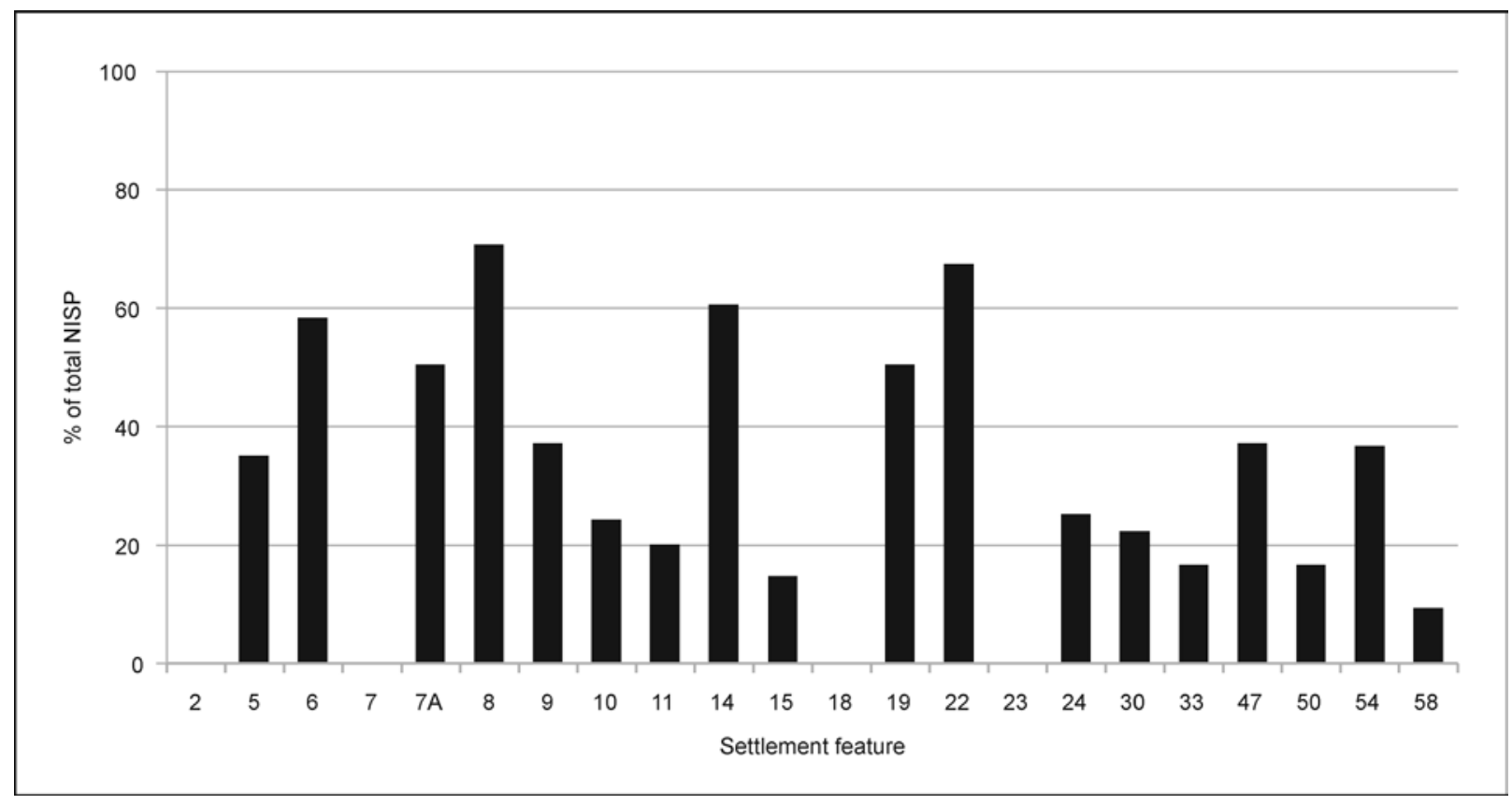

Fig. 8. Vel'ké Zálužie-Ďuriho sad. The incidence of gnawed bones in the studied features.

may also have resulted from other than anthropogenic factors, when it happened accidentally (Lyman 1994, 388). In the studied assemblage, clear traces of burning have been recorded in a single case - the small fragment of a femur shaft from a medium size mammal was retrieved from house 47 . The inflicted area is located at the bone's margins and has redbrownish to black coloration. This suggests short time exposure to open fire (ca $250-550^{\circ} \mathrm{C}$ according to the Shipman's scheme in Lyman 1994, 386, fig. 9). This points to its possible relationship with food preparation on site. No other specimen showed discoloration by fire or other marks of alternative heat exposure. This may suggest that the roasting over open fire was not a 'preferred' method of meat preparation. The observed butchery patterns are also congruent with boiling (in the pots?), baking or roasting meat without attached bones. On the other hand, the general lack of burned specimens in the assemblage may also indicate that bones were not used as a fuel or discarded in the fire. Most probably, after the removal of edible soft tissues, bones were accessible to scavengers (dogs or domestic pigs?). Subsequently they may have been cleaned out from the inhabitation area intentionally - into open refuse pits or abandoned habitation areas. Such a scenario is supported by frequently recorded marks of carnivore gnawing.

\section{Gnawing}

Approximately one third of the assemblage bears signs of gnawing (32.4\% of NISP). ${ }^{10}$ These specimens occurred in most features and in all species identified (Fig. 8). Except for dogs, other domestic or wild scavengers such as pigs, wolves, cats or rodents may contributed to the destruction and scattering of animal bones. The typical marks of mid- to large-sized carnivores include shallow or deep pits and punctures of circular/ irregular shape, broad grooves and ragged ends (after Lyman 1994, 205-216; see also Binford 1981; Reitz/Wing 1999, 133-135). Similar pattern may be produced by pigs (Greenfield 1988), but the absence of marks left by their long, shovel-shaped lower incisor teeth on bones indicates that canids were the main scavengers at Vel'ké Zálužie. It is clear that dogs were present at the site and fed on human leftovers, which is also supported by the mutual occurrence of butchery and gnawing marks in most of specimens. Nevertheless, the studied assemblage did not provide examples of digested bones, so the direct evidence on feeding the dogs with human food refuse is not available.

The investigated bone material bears no signs of rodent gnawing. Was the access to the garbage restricted for small scavengers or were they missing

\footnotetext{
10 The overall proportion of gnawed specimens in the studied assemblage may be underrepresented, since only clear marks of carnivore teeth were recorded. The questionable bone splinters that may also have resulted from carnivore activity were not quantified.
} 
Tab. 4. Vel'ké Zálužie-Ďuriho sad. The basic information on worked bones.

\begin{tabular}{|c|c|c|c|c|c|c|c|c|c|}
\hline Specimen & Species & Element & Part of element & Modification & Colouring & $\begin{array}{l}\text { Weight } \\
\text { [g] }\end{array}$ & $\begin{array}{l}\text { Length } \\
{[\mathrm{mm}]}\end{array}$ & $\begin{array}{c}\text { Max. } \\
\text { diameter } \\
{[\mathrm{mm}]}\end{array}$ & Feature \\
\hline $17 / 1$ & Cattle & costae & large fragment & striation, polishing & dark brown & 69.3 & 261.5 & - & 15 \\
\hline $17 / 20$ & Red deer & cornus & tin fragment & cut/saw off, polishing & dark brown & 9.8 & 61.2 & 18.0 & 15 \\
\hline $19 / 11$ & Cattle? & costae & small fragment & striation, polishing & beige & 7.8 & 61.0 & - & 10 \\
\hline $23 / 5$ & Cattle & talus & $\begin{array}{l}\text { completely } \\
\text { preserved }\end{array}$ & $\begin{array}{l}\text { polished facets } \\
\text { on plantar surface }\end{array}$ & beige & 87.4 & 67.2 & - & 9 \\
\hline $23 / 6$ & Cattle & radius & diaphysis fragment & polishing & light brown & 49.4 & 126.1 & - & 9 \\
\hline
\end{tabular}

at the site? Hard to decide, because when dogs can 'play with food leftovers', it is usually accessible for rodents too.

\section{Worked bones}

The animal bones, teeth, antlers and horns are common raw materials used in manufacturing tools and decorations in the Late Roman period and Germanic cultural milieu (e.g. Hrnčiarik 2014; 2015; Zeman 2001). Research on locally produced items suggested that manufacturing techniques were very similar to those used by Romans and that variety of saws, knives and drills had been employed (Hrnčiarik 2015, 21). Simple implements were usually made at home from animal skeletal elements whose shape best suited the desired function. Such objects accompanied people of all social levels as a part of their lives, households and workshops equipment (Zeman 2001, 140). At Vel'ké Zálužie, a small collection of worked bones has been registered $(1.6 \%$ of total NISP; Tab. 4). Their taxonomic and anatomic identifications suggest the preference and/or availability of large mammal bones - red deer antlers and postcranial elements of cattle. One antler fragment bears signs of manufacturing, while other 'worked' bones display only use-wear.

The worked antler fragment 17/20 has already been registered during field work (small find nr. 7). The cut-off tine originated from the beam of a hunted red deer or a shed antler. Its greatest length is $61.2 \mathrm{~mm}$ and the object shows notable polishing on all surfaces (Fig. 9: 1). On the proximal end of the fragment, parallel striations caused by cutting/sawing off the beam, perhaps by a metal implement, are clearly recognizable (Fig. 9: 2). On the other side, the object ends by a highly polished and slightly flattened tip, whose surface is dis- rupted by grooves caused by root etching (Fig. 9: 3). The remaining surface bears multiple, randomly oriented scratches/grooves of either natural in vivo abrasion of the antler $(1)^{11}$, the handling/use of the implement during unspecified human activity connected to craft or household work (2), or weathering/ trampling of object after its discard (3). The object most probably represents rejected waste or a halffinished tool of unknown function. Therefore, the recorded scratches and polishing may have had multiple causes. Similar objects made of deer antlers are regularly present at Germanic sites in the southwestern Slovakia and used to be interpreted as waste material and half-finished products of local antler crafting (cf. Bíró et al. 2012; 38; Březinová et al. 2003, 57; Hrnčiarik 2014, 153, 154, fig. 3; Varsik 2011, 124; Zeman 2001, 138). Examples are known from Nitra-Chrenová, location Shell (Březinová et al. 2003, 182, tab. 30: 13, 14, 16), Branč (Kolník/Varsik/ Vladár 2007, 154, tab. 2: 2), Bratislava-Vajnory, location Pri Visáku (Varsik 2011, 374, tab. 64: 12-15), or Dunajská Lužná (Bazovský 2010, 21, fig. 6: 9-18). Similarly modified antler fragments were registered at Roman-provincial sites, for instance in Aquincum (e.g. Bíró et al. 2012, 29, fig. 14) or Iža (Hrnčiarik 2017, $83,134,135)$.

Other examples of bones probably modified by humans have been identified during analysis because they represent non-manufactured objects with only slight modifications. It seems that only one of them (specimen 23/5) shows clear use wear and traces of human handling (Fig. 9:4,5). The item is made of complete talus (syn. astragalus) of an adult cattle and bears two types of modifications. Multiple parallel cut marks, oriented transversally to the long axis of a bone are visible on the trochlea tali distalis. These may be related to carcass partitioning. In this case, the effector was a metal knife and the likely purpose was disarticulating the hock-joint of the

\footnotetext{
${ }^{11}$ Unless artificial modifications (i.e. scratches, polishing, deformation, or fracture) recorded in archaeological antlers are not clearly human induced and may arose from natural activity of a deer (e.g. rubbing against tree bark, male-male competition etc.), their origin or nature of the tool remain questionable (Jin/Shipman 2009).
} 


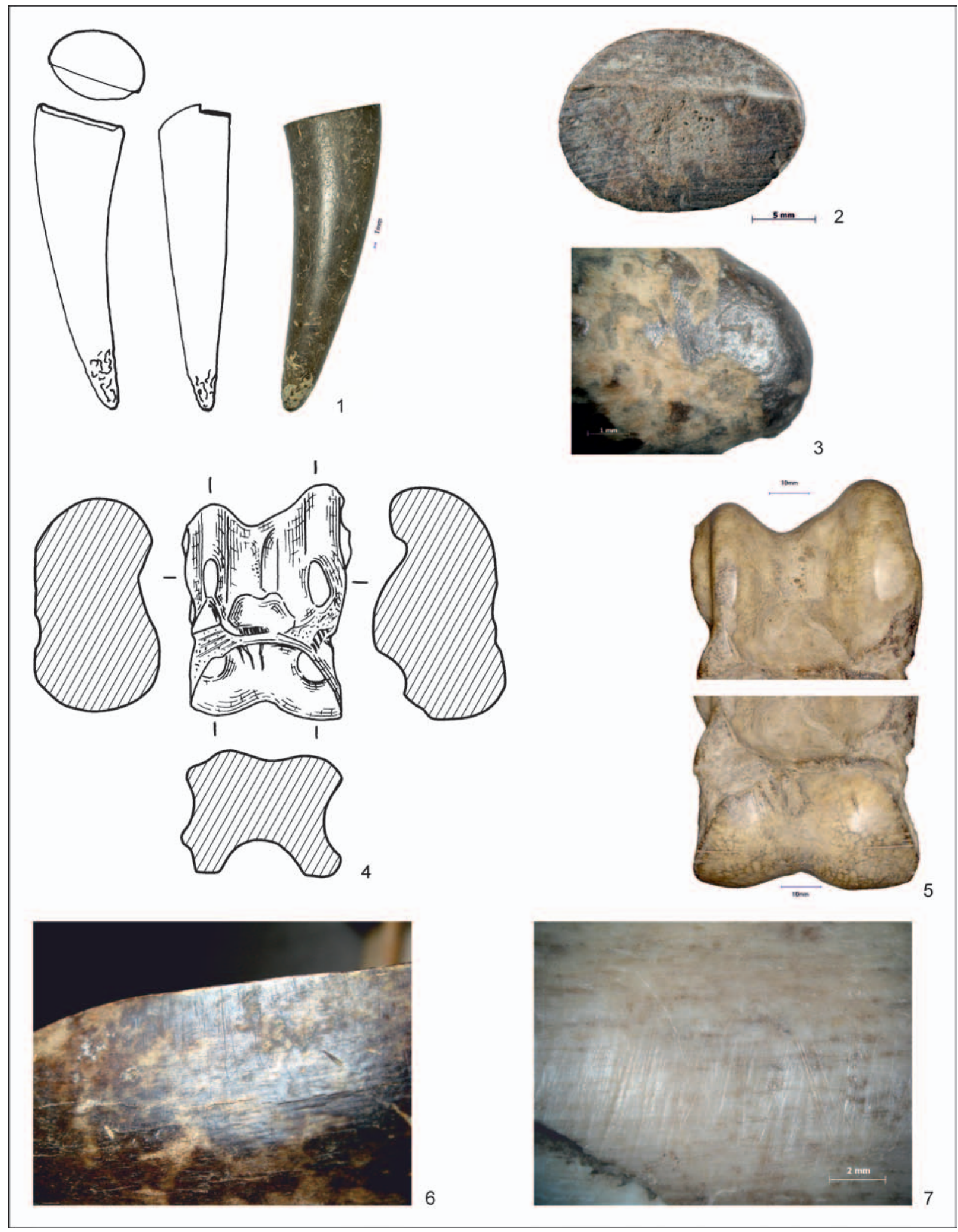

Fig. 9. Vel'ké Zálužie-Ďuriho sad. Worked bones. 1 - a cut/sawn-off antler tip (specimen 17/20); 2 - detail of the crosssection (proximal end) with multiple parallel cuts made by an metal implement (knife/saw); 3 - a detail of the antler very tip (distal end) with polished surface and grooving (imprints of plant root?); 4 - four views of cattle talus with the use wear facets; 5 - detail of highly polished facets and butchery marks on trochlea tali proximalis et distalis; 6 - parallel striation on the dorsal plane directed across the longer axis of a rib (specimen 17/1); 7 - parallel striation on the dorsal plane directed almost across the longer axis of a rib fragment (specimen 19/11). 
hind-foot that is separating the dry limb from the meaty parts of the carcass. Further, four oval facets are located on the protruding condyles of trochlea tali proximalis and trochlea tali distalis and cause flattening of the bone. All are highly polished and under the microscope reveal randomly oriented striations indicating the movement of the bone in multiple directions on a solid, perhaps soft support (made of wood, leather, or clay). The small extent of wear suggests short time use (e.g. Sidéra/Vornicu 2016). The artificially smoothened edges of this bone, probably resulting from handling, are also notable.

This object is reminiscent of a similarly modified astragalus (talus or knuckle bone), known from archaeological, iconographic as well as documentary sources as game pieces (e.g. Bartosiewicz 1999; Hrnčiarik 2015, 64-66). Nevertheless, such finds are rarities in the studied region and period. A single case from Dunajská Lužná includes 17 knuckle bones and the bone counter (Bazovský 2010; Miklíková 2010). Their analysis revealed slight overall polishing of the margins, indicating tossing and turning that are different from what we observed in the find from Vel'ké Zálužie. By the type of modifications, our specimen shows parallels to worked knuckle bones from early medieval Pohansko (Švecová 2001, 150-152, fig. 1: 2; 2: 3) or the prehistoric finds from Pavlovac-Kovačke Njive in Serbia (Vitezović 2014). There revealed astragali showed strong flattening and abrasion of the condyles. In Pohansko, astragali were interpreted as game pieces, in Pavlovac (the bones were also perforated) as tools used in textile/leather or pottery production. The use of tali as scrapers or burnishers of ceramics and/or hide has been suggested elsewhere (e.g. Buko 1990, 129, fig. 54c; Meier 2013; Rogatko 1994). However, similarly modified tali appeared also in connection with rituals, functioning as amulets, fortune-telling and magic devices (e.g. Bartosiewicz 1999; Birtalan 2003; Lehmkuhl 1984; Śvecová 2001; Trantalidou/Kavoura 2008). Unless experimental work (e.g. Meier 2013; Sidéra/Vornicu 2016) will bring significant and specific results, the interpretation of recorded use-wear will remain open and new finds should be classified simply as objects of 'special use' (after Vitezović 2016, 116, tab. 4).

The remaining 'worked' bones within our collection represent rather questionable such objects. The first item is a circa $26 \mathrm{~cm}$ long cattle rib fragment (specimen 17/1). It has a smooth, polished surface and broken edges. Microscopic inspection of the surface revealed an isolated area of fine oblique striations located on the lateral side. The scratches are oriented transversally to the bone's long axis (Fig. 9: 6). The proximal end of this rib fragment is rounded, perhaps intentionally, and does not show specific use wear. The distal end is damaged by canid gnawing. Similar modifications were observed on another, but shorter rib fragment (specimen 19/11). The surface showed a slight polish and one of its partially destroyed ends is (intentionally?) rounded. The area on its lateral side shows parallel and oblique striations, oriented more-or-less transversally to the long axis of the rib (Fig. 9: 7). The opposite end cannot be studied since it has been recently broken off. Both rib fragments bear similar modifications - the shape and extent of striations (oblique, located on the dorsal side of the bone) - suggestive of similar use. Similar cattle ribs with use-wear including striations on the surface and smoothed edges with oblique file marks have been described for instance from Roman Virunum in southern Austria as the textile implements used for the loom work, for beating the weft (Gostenčnik 2010). In beaters, the file-marks were also partly running along the edges that were first rounded and smoothed so that the working of threads was not impaired (see Gostenčnik 2010, 154, fig. 8f). However, those implements differ from our finds. Our specimens do not have distinctive worked tips and show a different manufacturing process (beaters were made from split ribs). Similar items from Iža were brought into connection with household and/or crafting activities including work with textile, hide, plant, or pottery (Hrnčiarik 2015, 76, 77; Zeman 2001, 138). These functions, however, remain questionable, similarly to the last item from Vel'ké Zálužie (specimen 23/6). This piece is a large cattle radius shaft fragment (13 cm long) with some polishing at one of its ends and general smoothening or rounding of the fragment edges and fractured margins. In contrast to the rib fragments, during microscopic inspection no specific use-wear has been recognized on the surface of this bone. It may thus represent a 'pseudo-tool' or a tool used very shortly.

\section{Weathering and fragmentation}

After the human processing of animal carcasses, the assemblage enters into following taphonomic phases of its history which, among others, includes weathering and the further fragmentation of bones. The examined specimens had only slightly weathered bone surfaces (stage 1 after Behrensmeyer 1978). This condition has been recorded also in bones of juvenile individuals that are most vulnerable to the water activity, precipitation, freezing, plant root etching and the acidity $(\mathrm{pH})$ of the surrounding sediment. It points either to generally favourable conditions of soil at the site or rapid burial, i.e. the limited time between the discard and deposition 


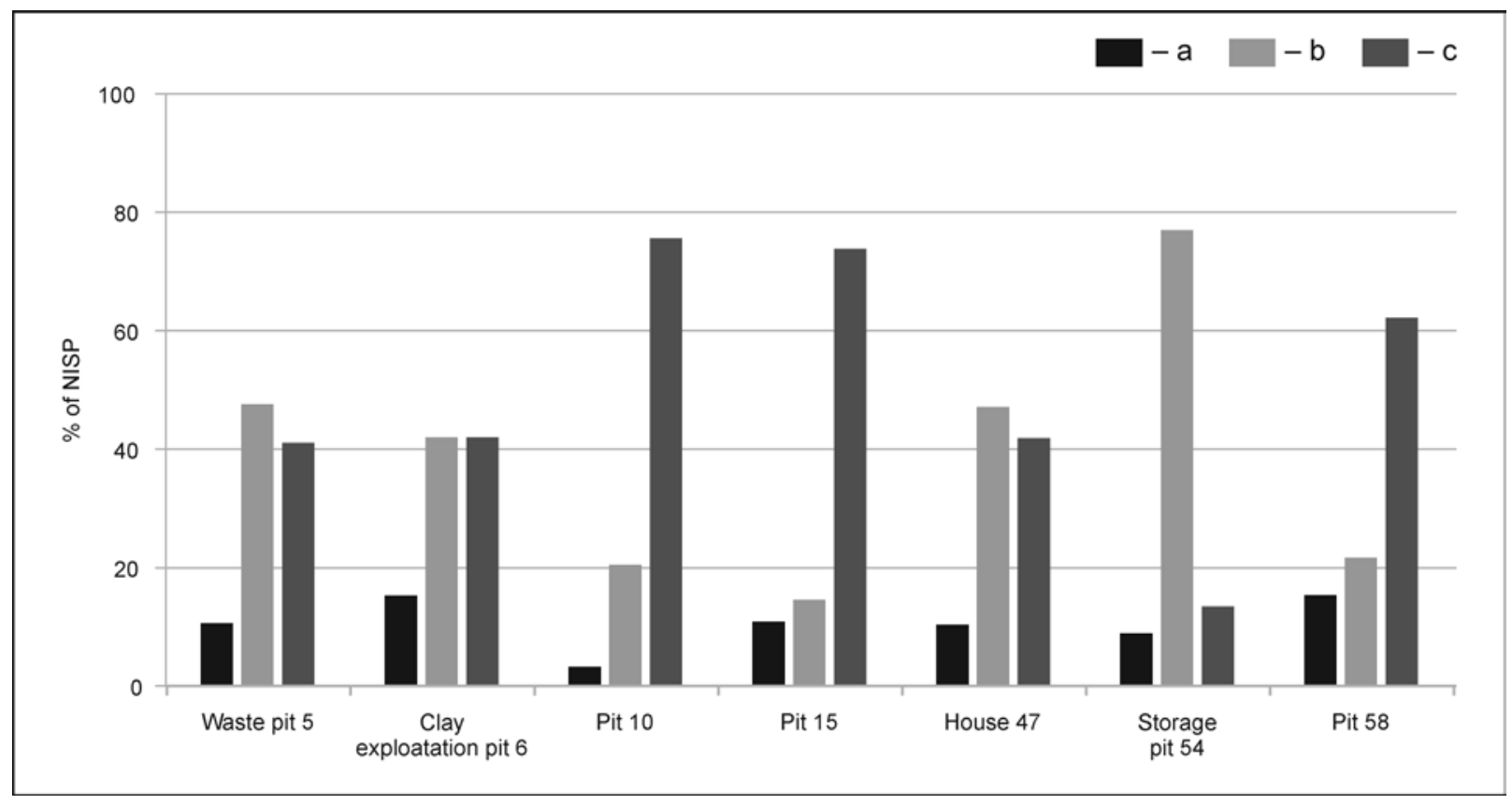

Fig. 10. Vel'ké Zálužie-Ďuriho sad. Bone preservation in selected settlement features. Legend: a - complete elements; $\mathrm{b}$ - partly preserved elements; $\mathrm{c}$ - fragments.

of kitchen waste (ca 0-3 years after the animals' death). It also indicates that the bones had a similar taphonomic history including near-identical depositional circumstances which, at the end shows that the assemblage was accumulated during similar phases of settlement use. It seems that the majority of bone refuse was thrown into the pits intentionally or fell there accidentally shortly after being exposed on the ground surface. There was variation in the bone colouration recorded - from bright beige to dark brown that most probably relate to the colour and composition of immediate soil matrix.

It is clear that during and after deposition, bones were further fragmented and disintegrated by human (e.g. trampling on the ground surface, etc.), and animal action or soil. All these factors resulted in the overall moderate fragmentation of bones. Half of the assemblage consisted of bone fragments $(50.8 \%$ of total NISP). The other half is composed of complete $(13.4 \%)$ or partially broken skeletal elements $(35.8 \%)$. Regarding bone fragmentation across the site, no significant differences in the proportion of complete elements per feature were observed (Fig. 10). However, some differences are recorded when fragmented material distribution is studied. Pits 10, 15 and 58 yielded much more fragmented material than other features that can suggest a slow, multi-phased formation of their infill. On the other hand, a high proportion of complete and partially preserved bones in storage pit 54 is caused by the presence of a deer skeleton, most probably dumped into the pit during a single event ${ }^{12}$. The variation in the preservation of bones of identified species is given in Tab. 5. The variations observed perhaps reflect the differential preservation of bones from large and medium sized mammals but may also be related to food preparation practices.

\section{Animal taxa and dietary patterns}

At least seven species and 29 individuals were present in the assemblage (Tab. 6). Domestic taxa included cattle (Bos taurus L.), pig (Sus domesticus Erxl.), sheep (Ovis aries L.), horse (Equus caballus L.) and dog (Canis familiaris L.). Bones or teeth of a goat were not identified, but their presence among caprine (Ovis/ Capra) remains cannot be excluded. Wild animals were represented by red deer (Cervus elaphus L.) and roe deer (Capreolus capreolus L.). In some cases, the wild and domestic forms of animals could not be distinguished, so specimens were attributed to wider taxonomic groups ( $3.4 \%$ NISP). Unidentified specimens made up $20.2 \%$ of the total number of finds. This group of finds was classified according to the size of the animal they possibly represented

\footnotetext{
12 The recovery circumstances of partial deer skeletons, including the exact position of bones in the pit and degree of articulation remain unclear.
} 
Tab. 5. Vel'ké Zálužie-Ďuriho sad. The bone fragmentation degree.

\begin{tabular}{|c|c|c|c|c|c|c|c|c|c|c|c|c|c|c|c|c|c|}
\hline Bone fragmentation & 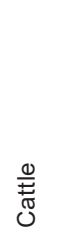 & .09 & $\begin{array}{l}\stackrel{0}{\Phi} \\
\frac{\Phi}{\omega}\end{array}$ & 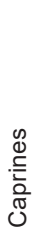 & $\begin{array}{l}0 \\
\text { D. } \\
\text { 오 }\end{array}$ & চ) & 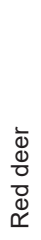 & 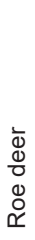 & 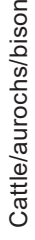 & 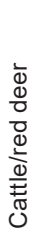 & 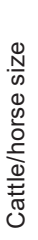 & 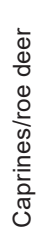 & 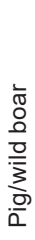 & 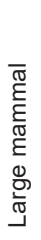 & 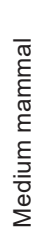 & 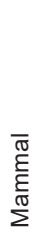 & $\frac{n}{2}$ \\
\hline Complete & 14 & 1 & 1 & 1 & - & 1 & 1 & - & - & - & - & - & - & - & - & - & 19 \\
\hline Complete (disrupted) & 9 & 4 & 2 & - & - & 2 & 2 & - & - & - & - & - & 1 & - & - & 1 & 21 \\
\hline $\begin{array}{l}\text { Complete (without } \\
\text { epiphysis) }\end{array}$ & - & 1 & - & - & - & - & 2 & - & - & - & - & - & - & - & - & - & 3 \\
\hline More than half (ca. 3/4) & 11 & 5 & 4 & 3 & 1 & - & 1 & - & - & - & - & 5 & - & - & 1 & - & 31 \\
\hline Half (ca. 1/2) & 13 & 7 & 2 & 6 & - & 1 & 12 & - & - & - & - & - & - & - & - & 1 & 42 \\
\hline Less than half (ca. 1/4) & 11 & 9 & 1 & 8 & 1 & - & 6 & - & - & 1 & 1 & - & - & - & 3 & 1 & 42 \\
\hline Fragment & 34 & 17 & - & 11 & - & - & 2 & 1 & 1 & 2 & 1 & 4 & - & 11 & 7 & 5 & 96 \\
\hline Small fragment & 16 & 5 & - & 4 & - & - & 3 & - & - & 1 & - & 1 & - & 10 & 14 & 8 & 62 \\
\hline Very small fragment & - & - & - & - & - & - & 2 & - & - & - & - & - & - & 1 & - & 2 & 5 \\
\hline Total & 108 & 49 & 10 & 33 & 2 & 4 & 31 & 1 & 1 & 4 & 2 & 10 & 1 & 22 & 25 & 18 & 321 \\
\hline
\end{tabular}

Tab. 6. Vel'ké Zálužie-Ďuriho sad. The representation of animal taxa according to three quantification methods: NISP - number of identifiable specimens; MNI - minimum number of individuals; WISP - weight of identified specimens.

\begin{tabular}{|c|c|c|c|c|c|c|c|c|c|}
\hline Animal taxa & NISP & $\%$ & $\%$ of domestic & MNI & $\%$ & $\%$ of domestic & WISP & $\%$ & $\%$ of domestic \\
\hline Horse & 2 & 0.6 & 1.0 & 2 & 6.9 & 8.3 & 294.2 & 3.2 & 3.7 \\
\hline Cattle & 108 & 33.7 & 52.4 & 7 & 24.1 & 29.2 & 5688.9 & 61.5 & 70.7 \\
\hline Pig & 49 & 15.3 & 23.8 & 9 & 31.0 & 37.5 & 1336.0 & 14.4 & 16.6 \\
\hline Caprines & 33 & 10.3 & 16.0 & 4 & 13.8 & 16.7 & 501.7 & 5.4 & 6.2 \\
\hline Sheep & 10 & 3.1 & 4.9 & 1 & 3.4 & 4.2 & 207.7 & 2.2 & 2.6 \\
\hline Dog & 4 & 1.3 & 1.9 & 1 & 3.4 & 4.2 & 14.9 & 0.2 & 0.2 \\
\hline Domestic total & 206 & 64.2 & 100.0 & 24 & 82.8 & 100.0 & 8043.4 & 86.9 & 100.0 \\
\hline Red deer & 31 & 9.7 & - & 4 & 13.8 & - & 527.2 & 6.2 & - \\
\hline Roe deer & 1 & 0.3 & - & 1 & 3.4 & - & 7.0 & 0.1 & - \\
\hline Wild total & 32 & 10.0 & - & 5 & 17.2 & - & 579.2 & 6.3 & - \\
\hline Cattle/aurochs/bison & 1 & 0.3 & - & - & - & - & 9.9 & 0.1 & - \\
\hline Cattle/red deer & 4 & 1.3 & - & - & - & - & 73.1 & 0.8 & - \\
\hline Pig/wild boar & 1 & 0.3 & - & - & - & - & 10.7 & 0.1 & - \\
\hline Caprines/roe deer & 10 & 3.1 & - & - & - & - & 50.4 & 0.5 & - \\
\hline Cattle/horse size & 2 & 0.6 & - & - & - & - & 17.2 & 0.2 & - \\
\hline Domestic/wild total & 11 & 3.5 & - & - & - & - & 61.1 & 0.7 & - \\
\hline Large mammal & 22 & 6.9 & - & - & - & - & 338.0 & 3.7 & - \\
\hline Medium mammal & 25 & 7.8 & - & - & - & - & 112.7 & 1.2 & - \\
\hline Mammal & 18 & 5.6 & - & - & - & - & 122.8 & 1.3 & - \\
\hline Unidentified & 65 & 20.2 & - & - & - & - & 573.5 & 6.2 & - \\
\hline Identified & 256 & 79.8 & - & - & - & - & 8683.7 & 93.8 & - \\
\hline Total & 321 & 100.0 & - & 29 & 100.0 & - & 9257.2 & 100.0 & - \\
\hline
\end{tabular}


(e.g. large mammal, medium sized mammal). All quantitative methods clearly indicated the predominance of domestic animals in the assemblage. Their proportion ranges from $64.2 \%$ by NISP to $86 \%$ by WISP. The remaining portion belonged to the wild animals - from $6.2 \%$ by NISP to $17.2 \%$ by WISP (Tab. 6). We observe a similar order of species when considering number and weight of specimens: cattle - pig - caprine - red deer. In contrast to that, MNI ranks pig as the species best represented in the studied assemblage (31 \% MNI). According to this method, cattle belong to the second (24.1\%) and caprines together with deer to the third most common taxa (17.2\%). The relatively high representation of cervids (mostly Cervus elaphus) is marked by mostly postcranial skeletal elements represented in the assemblage (see next chapter). The bones of horse and dog occurred in incomparably smaller quantities $(0.6 \%$ and $1.2 \%$ of NISP; $8.3 \%$ and $4.2 \%$ of MNI). Considering the spatial distributions, the balanced importance of cattle and pig at the site is suggested by the regular presence of both species in the settlement features (cattle bones presented in 18, pig in 15 features; Tab. A1). The single hut with sunken floor, however, yielded no cattle bone, only pig and caprine remains were found in this feature. This is perhaps the consequence of discarding large bones outside the immediate direct habitation space. Deer bones were scattered among seven of the explored features. Nevertheless, their abundance notably differs from those of the main domesticates since the majority of finds belonged to more or less complete deer skeletons in the refuse/ storage pits 50 and 54 .

As far as taxonomic composition is concerned, the studied assemblage showed a complete absence of bird and fish bones. The question is why since the proximity of water bodies (small river channels, lakes) suggests that people living here could have exploited all available food resources. Moreover, the keeping of domestic birds, mainly chicken and goose, was common practice already during the Late Roman. (Ambros 1970, 11; cf. Benecke 1994; Vörös 2002). In the case of Vel'ké Zálužie the most possible cause behind the absence of fish and birds is a recovery bias consonant with the small number of analysed finds. Also the recent archaeozoological analysis of other Germanic sites from the region (Hurbanovo) showed that if water flotation and sorting of hard residues is carried out, a greater variety of taxa are recovered in the assemblage (e.g. fish bones and scales, insects fragments, mol- luscs or coprolites; Hajnalová et al. 2018). At Vel'ké Zálužie the bones were only hand-retrieved which probably caused that gracile and small bones were overlooked. A look at regional data reveal general scarcity of fish or bird bones (Tab. 7). Both vertebrate classes are poorly represented even in large handretrieved assemblages, for instance Vel'ký Meder, where over three thousand identified specimens yielded only nine bird and 16 fish bone fragments (Fabiš/Bielichová 2014, 173, tab. 2). The emphatically interdisciplinary focus of research carried out at this site in 2003 included systematic sampling of the infill of three houses with sunken floors, however, suggested a far richer taxonomic diversity of fish, reptiles or birds (Varsik 2003a). ${ }^{13}$ The absence of fish was also reported from the Germanic settlements situated on the Danube (Štúrovo - Ambros 1984). Poultry, although more regularly reported (e.g. in Štúrovo $n=7$; Cífer-Pác $n=13$ ), occurred usually in very low numbers which sending us back to the basic question if it is a result of recovery bias or what exactly the role of breeding birds and fishing for Germanic people. To judge this part of animal economy on the basis of the scanty bone evidence available is impossible in the absence of fine recovery methods. So far, the representation of both taxa on Germanic sites (birds $1 \%$, fish $0.2 \%$ of NISP in average; see Tab. 8) support the idea of a minor role in the subsistence.

Last but not least, possible effects of scavenger activity, widely recorded at the site, must also be take into account. The bones of small species and young individuals are ingested by dogs or pigs with much greater probability.

The proportion of wild mammals at Vel'ké Zálužie is rather striking. By NISP they comprise $10 \%$, by WISP $6.3 \%$ while by MNI $17.2 \%$. Compared to other Germanic sites from southwest Slovakia (Tab. 7) this proportion is the highest recorded yet. Similarly to the absence of birds and fish remains, this result may also be multicausal. At first we need to look at the quantification methods. If the NISP is considered, it is clear that the proportion of wild mammals is over-estimated due to the inclusion of elements from the partial red deer skeleton. On the other hand, the WISP and MNI quantification methods balance for this bias and indicate directly the amount of meat and number of individuals provided by deer. On the basis of these results we can assume that wild mammals (especially cervids) played a similarly significant role in meat supply as caprines. Although small

\footnotetext{
${ }^{13}$ One of the aims of this project was to show how recovery methods and sampling strategy can affect archaeozoological analysis. Archaeobotanical samples were already analysed and evaluated (Hajnalová/Varsik 2010; 2015), while 100 flotation and 97 hand-retrieved archaeozoological samples still await the analysis.
} 


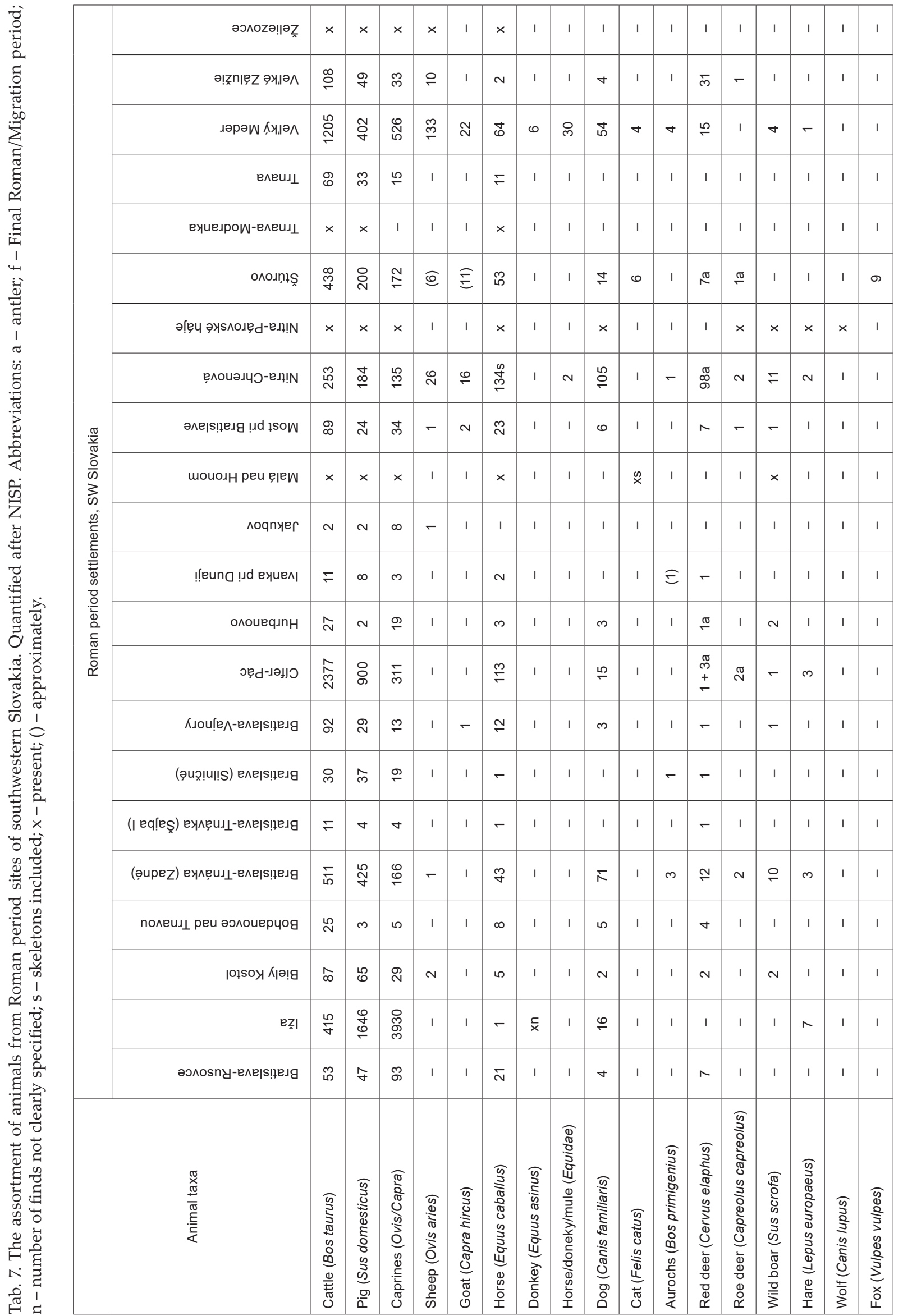




\begin{tabular}{|c|c|c|c|c|c|c|c|c|c|c|c|c|c|c|c|c|c|c|}
\hline \multirow{22}{*}{ 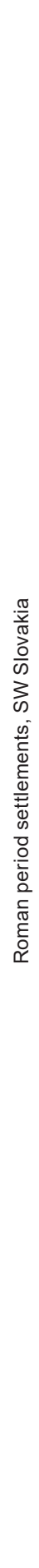 } & әэ^০Zə!|əZ్ & 1 & 1 & 1 & 1 & 1 & 1 & 1 & 1 & 1 & 1 & 1 & 1 & 1 & 1 & 1 & 1 & 1 \\
\hline & 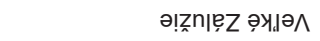 & 1 & 1 & 1 & 1 & 1 & 1 & 1 & 1 & 1 & 1 & 1 & 1 & 1 & 1 & 1 & 1 & 1 \\
\hline & 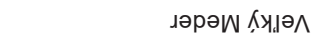 & 1 & 1 & $\stackrel{\mathscr{N}}{2}$ & 0 & 1 & 1 & 1 & - & - & - & 1 & 1 & 1 & 1 & 1 & $\stackrel{\varphi}{\sim}$ & - \\
\hline & елеUА & 1 & 1 & 1 & 1 & 1 & 1 & 1 & 1 & 1 & 1 & 1 & 1 & 1 & 1 & 1 & 1 & । \\
\hline & еуиелроW-елеил & 1 & 1 & 1 & 1 & 1 & 1 & 1 & 1 & 1 & 1 & 1 & 1 & 1 & 1 & 1 & 1 & 1 \\
\hline & O^oג!̣ıs & 1 & 1 & 1 & n & $m$ & 1 & 1 & 1 & 1 & 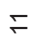 & 0 & 1 & 1 & 1 & 1 & - & ஓे \\
\hline & 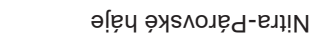 & 1 & 1 & 1 & $x$ & 1 & 1 & 1 & 1 & 1 & $x$ & 1 & 1 & 1 & 1 & 1 & $x$ & I \\
\hline & อุ^оиәдบว-Еג!?!N & 1 & - & - & - & 1 & 1 & 1 & 1 & 1 & 1 & N & 1 & 1 & 1 & 1 & 1 & I \\
\hline & 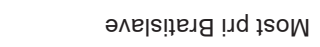 & 1 & 1 & $r$ & N & 1 & 1 & 1 & 1 & 1 & 1 & 1 & 1 & I & 1 & 1 & 1 & $\stackrel{\infty}{-}$ \\
\hline & mouodн peu ejew & 1 & 1 & 1 & 1 & 1 & 1 & 1 & 1 & 1 & 1 & 1 & 1 & 1 & 1 & 1 & 1 & 1 \\
\hline & лoqnyer & 1 & 1 & 1 & - & 1 & 1 & 1 & 1 & 1 & 1 & 1 & 1 & 1 & I & 1 & 1 & 1 \\
\hline & !euna !dd еучues| & 1 & 1 & 1 & ल्ర & 1 & 1 & 1 & 1 & 1 & 1 & 1 & 1 & 1 & 1 & 1 & 1 & I \\
\hline & oлouequnH & a & 1 & 1 & 1 & 1 & 1 & 1 & 1 & 1 & I & 1 & - & 1 & 1 & 1 & $\omega$ & । \\
\hline & วеุ,-גəן! & 1 & 1 & 1 & $\stackrel{m}{=}$ & $\theta$ & 1 & 1 & 1 & I & 우 & 1 & 1 & 1 & I & 1 & - & 1 \\
\hline & 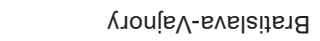 & 1 & 1 & 1 & 1 & 1 & 1 & 1 & 1 & 1 & 1 & 1 & 1 & 1 & I & 1 & 1 & I \\
\hline & 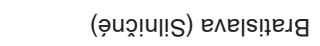 & I & 1 & 1 & - & - & 1 & $\bar{x}$ & 1 & I & 1 & 1 & 1 & 1 & 1 & 1 & 1 & - \\
\hline & 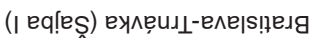 & I & 1 & 1 & 1 & 1 & 1 & 1 & 1 & I & 1 & I & 1 & 1 & I & 1 & 1 & I \\
\hline & (ọupeZ) еулерuд-елье|s!̣eגg & 1 & 1 & 1 & $\underset{\mathbb{N}}{\leftrightarrows}$ & 1 & 1 & I & 1 & 1 & I & 1 & 1 & 1 & I & 1 & $\sim$ & 2 \\
\hline & полеИА реи әэлоиерчоя & 1 & 1 & 1 & 1 & 1 & 1 & I & 1 & 1 & 1 & 1 & 1 & 1 & I & I & 1 & 1 \\
\hline & 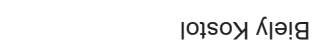 & 1 & 1 & 1 & 1 & 1 & I & I & 1 & 1 & 1 & 1 & 1 & 1 & I & I & 1 & 0 \\
\hline & EZ्रl & 1 & 1 & 1 & 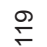 & 1 & 1 & 1 & 1 & 1 & 0 & 1 & 1 & $x$ & 1 & 1 & ले & $\nabla$ \\
\hline & әэмоsnу-еме|s!ฺедя & 1 & 1 & 1 & - & 1 & - & 1 & 1 & 1 & $\sim$ & 1 & I & I & - & - & - & 1 \\
\hline & 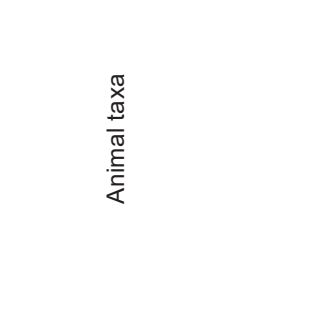 & 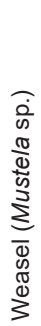 & 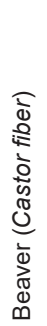 & 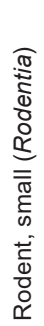 & 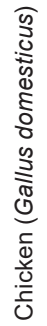 & 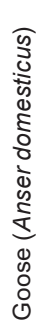 & 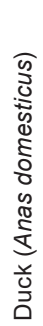 & 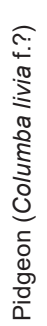 & 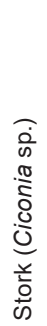 & 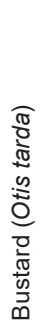 & 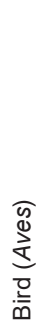 & 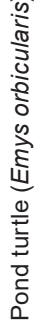 & 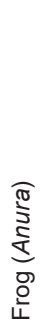 & 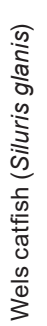 & 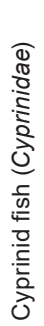 & 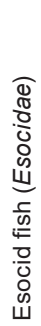 & 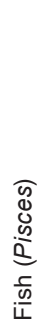 & 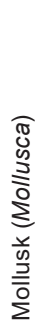 \\
\hline
\end{tabular}


Tab. 8. The representation of basic taxonomic groups at Roman period sites from the southwestern Slovakia (sites with less than 200 identified fragments not reconsidered). Remains of turtle, small rodents and unidentified specimens excluded from the calculation. ${ }^{*}$ - quantification include antlers.

\begin{tabular}{|c|c|c|c|c|c|c|c|c|c|c|c|c|c|}
\hline \multirow{2}{*}{ ID } & \multirow{2}{*}{ Site } & \multicolumn{2}{|c|}{ Domestic mammal } & \multicolumn{2}{|c|}{ Wild mammal* } & \multicolumn{2}{|c|}{ Domestic bird } & \multicolumn{2}{|c|}{ Wild Bird } & \multicolumn{2}{|c|}{ Fish } & \multicolumn{2}{|c|}{ Mollusc } \\
\hline & & NISP & $\%$ & NISP & $\%$ & NISP & $\%$ & NISP & $\%$ & NISP & $\%$ & NISP & $\%$ \\
\hline IŽ & Iža & 6008 & 97.7 & 7 & 0.1 & 119 & 1.9 & 6 & 0.1 & 3 & 0.0 & 4 & 0.1 \\
\hline BR & BA-Rusovce & 219 & 94.4 & 7 & 3.0 & 1 & 0.4 & 2 & 0.9 & 3 & 1.3 & - & 0.0 \\
\hline \multicolumn{2}{|c|}{ ROMAN-PROVINCIAL (average) } & - & 96.1 & - & 1.6 & - & 1.2 & - & 0.5 & - & 0.7 & - & 0.1 \\
\hline 1 & Biely Kostol & 190 & 95.0 & 4 & 2.0 & - & - & - & - & - & - & 6 & 3.0 \\
\hline 3 & BA-Trnávka & 1217 & 91.2 & 30 & 2.2 & 12 & 0.9 & - & - & 2 & 0.1 & 73 & 5.5 \\
\hline 7 & Cífer-Pác & 3716 & 99.0 & 10 & 0.3 & 17 & 0.5 & 10 & 0.3 & 1 & 0.0 & - & - \\
\hline 13 & Nitra-Chrenová & 855 & 88.1 & 115 & 11.8 & 1 & 0.1 & - & - & - & - & - & - \\
\hline 15 & Štúrovo & 901 & 92.9 & 17 & 1.8 & 10 & 1.0 & 11 & 1.1 & 1 & 0.1 & 30 & 3.1 \\
\hline 18 & Vel'ký Meder & 2446 & 98.0 & 24 & 1.0 & 6 & 0.2 & 3 & 0.1 & 16 & 0.6 & 1 & 0.0 \\
\hline 19 & Vel'ké Zálužie & 206 & 86.6 & 32 & 13.4 & - & - & - & - & - & - & - & - \\
\hline \multicolumn{2}{|c|}{ ROMAN-BARBARIC (average) } & - & 93.0 & - & 4.6 & - & 0.5 & - & 0.5 & - & 0.2 & - & 2.9 \\
\hline
\end{tabular}

sample size distorts the resulting picture, we presume that deer hunting played an important role in meat provisioning for the locals or at least for some of them. The data support the hypothesis that red deer was the most hunted game in southwestern Slovakia during the Roman period (Tab. 7). In some settlements, however, the contribution of red deer may be overestimated due to including all antler fragments into the total NISP. Antlers may also be collected when shed, without killing the whole animal for meat. An example is the settlement at Nitra-Chrenová where red deer remains comprise only antler fragments, likely related to the crafting of tools or decorations (Fabis 2003). This must be born in mind when judging the ratio of wild to domestic animals and their role in the diet. In general, wild mammals do not contribute more than $5 \%$ to total NISP at Roman-provincial sites in the region and the adjacent Barbaricum (Tab. 8). To add the picture, the diet was sporadically enriched by meat of wild boar, roe deer, and aurochs (the latter being the least represented). A wolf, fox, beaver or weasel also occurred among the prey but their dietary exploitation remains questionable. Domestic mammals make up more than $90 \%$ of the NISP at both Roman-provincial sites and in the Barbaricum. Domesticates were undoubtedly of the highest significance to the animal economy of the region. The species kept included cattle, sheep, goat, pig, horse, donkey, dog and cat, but their roles played in food provisioning (meat, milk) were different. Clearly, the dietary significance of the latter four species is questionable and should be assessed in light of eventual butchery marks as well as circumstances of recovery. At Vel'ké Zálužie, marks of defleshing or marrow exploitation are absent on horse and dog bones. This supports the hypothesis that neither of them formed a (regular) part of the menu. On the other hand, the absence of butchery marks does not exclude the possibility of their consumption (e.g. due to loss of primary function or shortage of meat for example), mainly if we remember fragmentary character of finds and immature age of one of the horse individual (see next chapters).

The possibility of hippophagia is supported by the presence of butchery marks reported from other contemporaneous sites (e.g. Fabiš/Bielichová 2014). In Hurbanovo for instance, cut/chop marks on a mandible fragment of a horse have been registered (Hajnalová et al. 2018). The strikingly larger proportion of horse bones at Nitra-Chrenová, on the other hand, is not a result of increased horse meat consumption but counting all elements of an intact single skeleton found in a pit (Fabiš 2003, 114, tab. 12a).

Regarding main farm animals, it can be assumed that inhabitants of Vel'ké Zálužie relied on beef and other edible parts of cattle including blood, fat and intestines. This is in accordance with previous results from Roman period assemblages in Slovakia where cattle bone finds dominate (Fig. 11). Although NISP values vary from site to site, the general 'cattle pattern' is evident. If available, additional quantification results (WISP, MNI) and the butchery data support the highest importance of cattle not only for the diet but also for the animal economy. The Germanic sites where sufficient numbers of finds were analysed clearly show a smaller representation of beef in meat provisioning at Biely Kostol, 


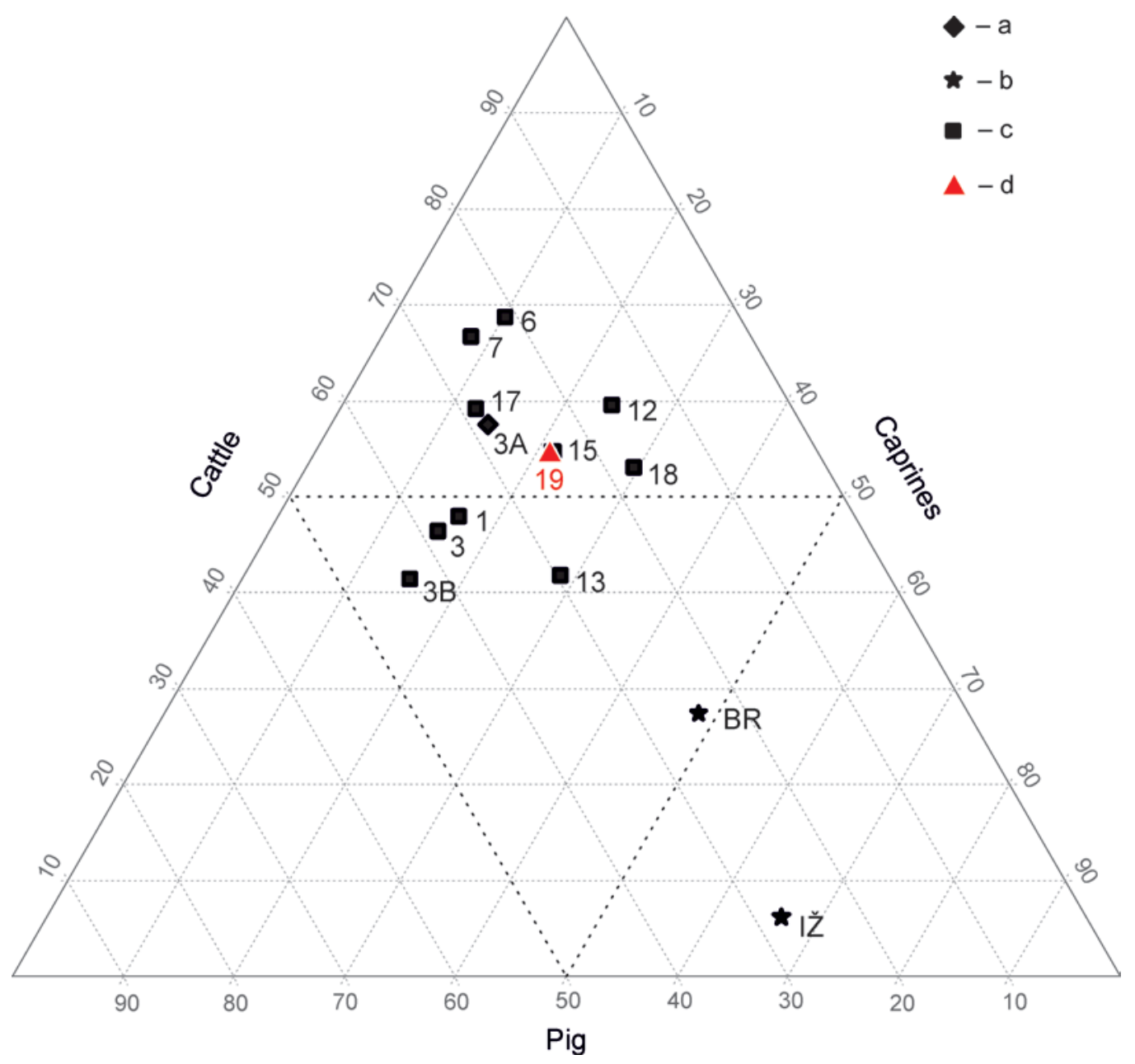

Fig. 11. The representation of main economic animals - cattle, caprines and pig at Roman period settlements from southwestern Slovakia (only sites with more than 150 identified fragments shown). Caprines include bones of sheep, goats and sheep/goat. For site code see Tab. 2. Bratislava-Trnávka, location Zadné (3) was divided according to the chronology into two sub-assemblages - earlier (3A) dated to $2^{\text {nd }} \mathrm{c}$. AD and later (3B) dated to $3^{\text {th }}-4^{\text {th }} \mathrm{c}$. AD. Legend: a - early RomanBarbaric; b - early Roman-Provincial; c - late Roman-Barbaric; d - Vel'ké Zálužie.

Bratislava-Trnávka, location Zadné and NitraChrenová. It seems that at first two sites more pork than beef was consumed, while at the third site more caprine (sheep?) remains were identified. When available, MNI results also suggest that beef was usually complemented with pork at the majority of sites. Cattle and pigs were slaughtered in equal numbers at Vel'ké Zálužie, Bratislava-Trnávka and Trnava-Horné pole. The growing popularity of pork towards the $3^{\text {rd }}$ and $4^{\text {th }} \mathrm{c}$. AD in the region of Bratislava was recently interpreted as resulting from an archaeologically detected increase in the local population and/or the Romanization of the diet (Hajnalová et al. 2018, 66; Šefč́áková 2011, 392). However, since pigs are better comparable to caprines in terms of individual meat output (Bartosiewicz $1993,126,127)$ we excluded cattle from the comparison of the regional data (Fig. 12). A diagram then shows that pigs outnumber caprines at Biely
Kostol, Bratislava-Trnávka and Cífer-Pác, while in Most pri Bratislave and Vel'ký Meder the caprines predominate. There are also sites such as Vel'ké Zálužie, Nitra-Chrenová and Štúrovo where the pig/caprine ratio is balanced. It is a question, what was the reason for this variability - whether pork consumption is indicative of a more stable, rich economy and general population increase, persisting or adopted tradition or it was related more to the local environmental conditions. The only clear 'outliers' in Fig. 11 or 12 are represented by food refuse from Roman-provincial military sites, such as IžaLeányvár and Bratislava-Rusovce. The dominance of caprine and/or pig bones within the material (by count and weight of identifiable specimens) clearly points to different cultural (culinary) tradition (e.g. King 2001). However, it is hard to explain why at similar Roman-provincial sites from the Middle Danube beef and pork usually prevail (cf. Bökönyi 


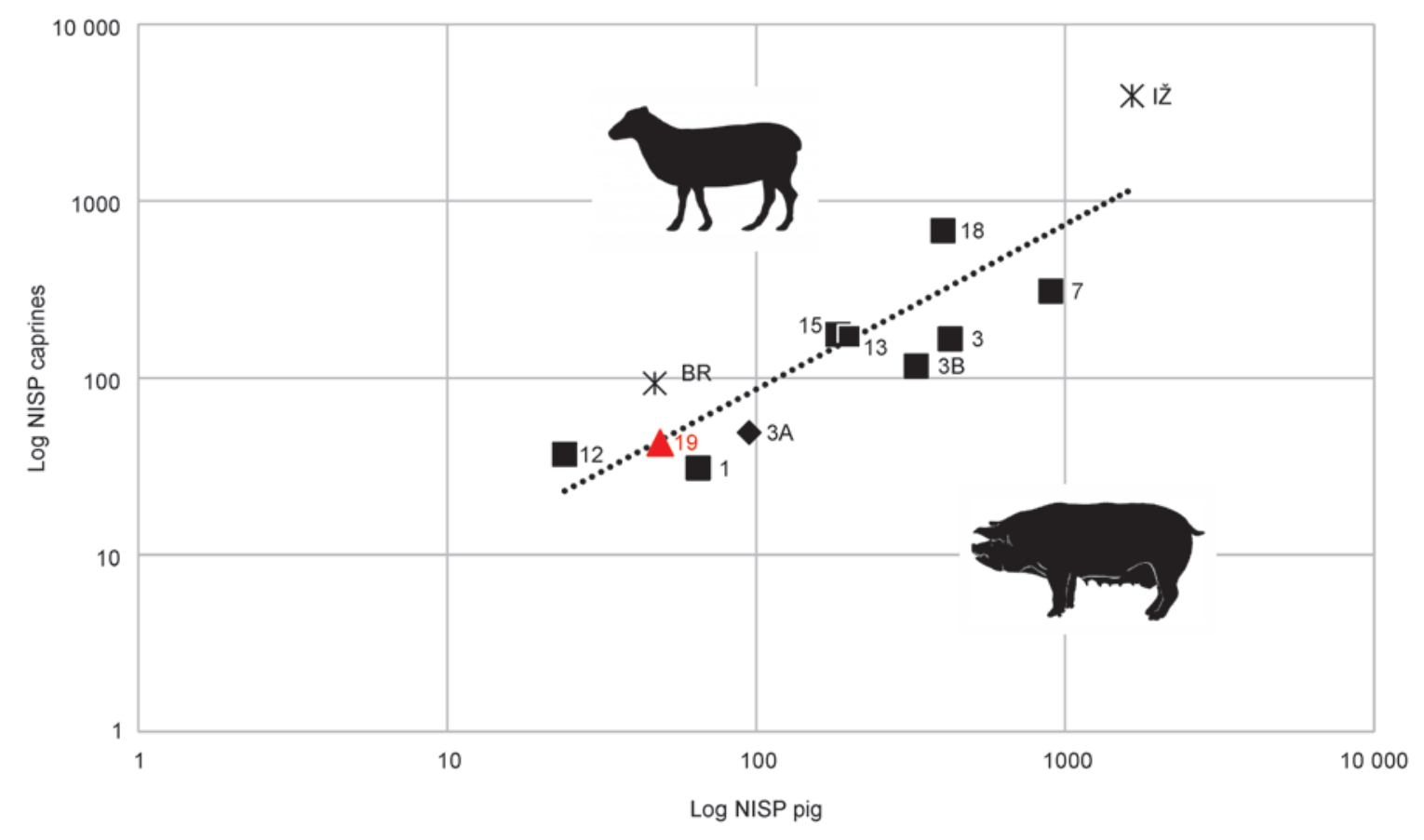

Fig. 12. The ratio of caprines to pigs at Roman period settlements from southwestern Slovakia (only sites with more than 150 identified fragments shown). Caprines include bones of sheep, goats and sheep/goats. For site code see Tab. 2. Bratislava-Trnávka, location Zadné (3) was divided according to the chronology into two sub-assemblages - earlier (3A) dated to $2^{\text {nd }} \mathrm{c}$. $\mathrm{AD}$ and later $(3 \mathrm{~B})$ dated to $3^{\text {th }}-4^{\text {th }} \mathrm{c}$. AD.

1984; Vörös 2002). Regarding a ‘Germanic dietary pattern', the continuity or change in time still cannot be fully studied due to the limited number of analyses carried out for early historic periods. So far, the composition of domestic species points to the persisting importance of cattle and caprines (sheep) from the Iron Age to the Early Roman period and the gradually increasing importance of pork during the Late Roman period (Hajnalová et al. 2018, 66). A 'beef and pork' pattern of the latter period has also been attested by our data.

\section{Skeletal element representation: a meat consumed?}

Several taphonomic factors, species diversity in skeletal anatomy, differential preservation as well as cultural factors (including transport, food preparation, disposal practices, activity areas, site status and animal trade) may have contributed to the representation of skeletal elements (e.g. Kysely 2004; Lyman 1994). In principle, animals kept in the proximity the site should display better skeletal representation because they were slaughtered locally or transported from shorter distance prior to consumption/deposition (Reitz/Wing 1999, 203). The occurrence of all main body parts at the studied settlement seems thus be indicative of local keeping, slaughtering or short-distance delivery (transport) of cattle, pig, caprines and red deer. According to NISP, the assemblage is dominated by rib and mandible fragments (Tab. A2). Relatively frequent are metacarpus, metatarsus, tibia, and radius. Other elements including vertebrae, humerus, femur or pelvis occurred least frequently. A similar pattern can be observed in all main domesticates - cattle, pig and caprines. Among the 108 cattle remains ribs, metapodials and mandible fragments prevail. In pigs and caprines the data are rather few but show the same trend. As far as differential preservation and anatomy is concerned, the prevalence of ribs can be explained by their anatomical multiplicity, high degree of butchery and fragility together with fair durability in large mammals. Mandibles were highly fragmented and heavily butchered too, but in contrast to the maxilla for example, the jaw is a more durable skeletal element guaranteeing a higher probability of survival both during deposition and recovery. On the other hand, the relative lack of humerus and femur fragments, bones also intensively butchered, may be attributed to their smaller degree of natural fragmentation as well as smaller number (only two each in the skeleton). 


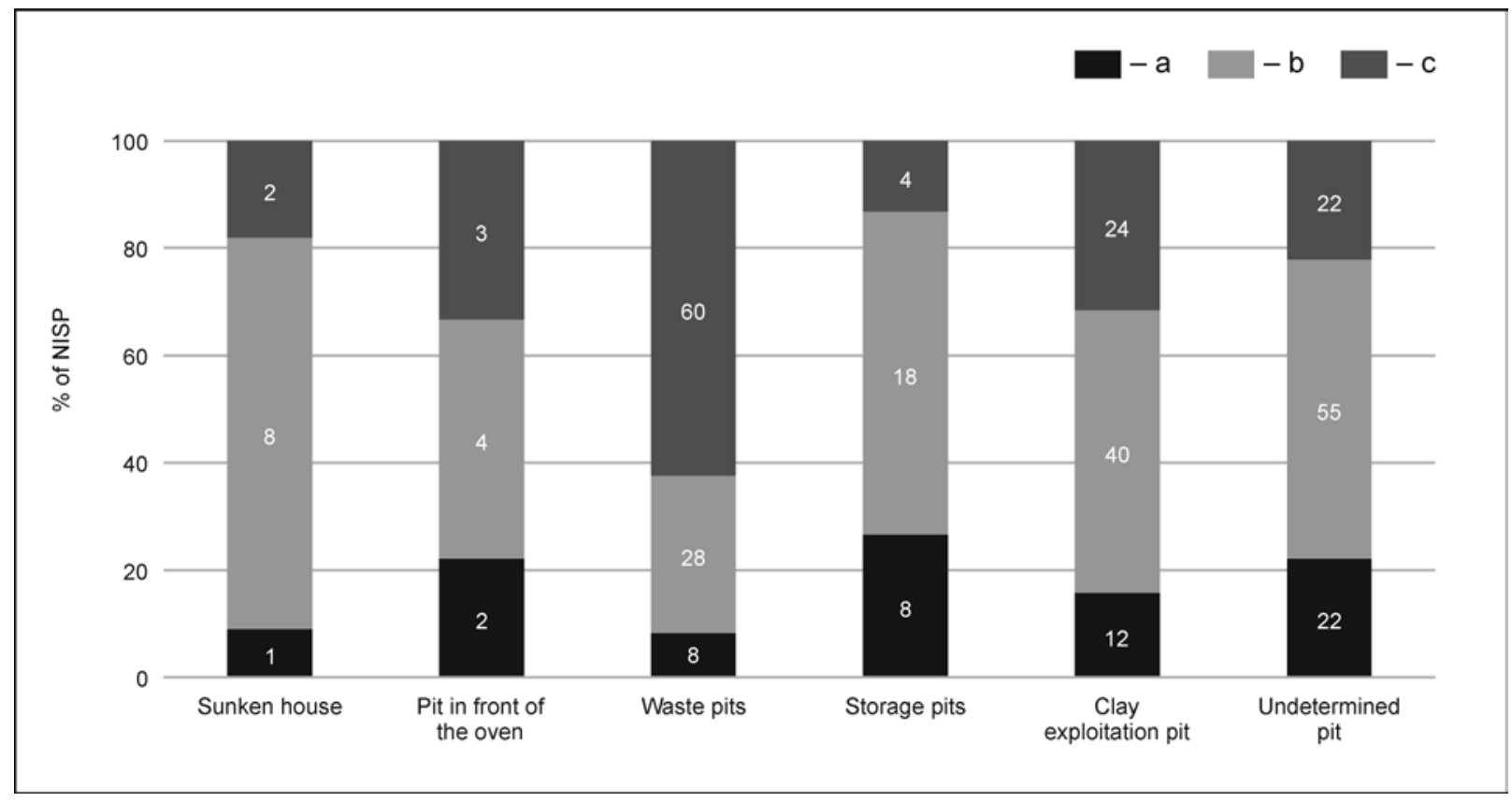

Fig. 13. Vel'ké Zálužie-Ďuriho sad. The representation of skeletal elements according to their 'meat value' (Uerpmann 1973) in identified types of settlement features. The quantification exclude horn-cores, antlers, teeth and anatomically unidentified specimens. Legend: $\mathrm{a}$ - high; $\mathrm{b}$ - medium; c - low meat value.

Regarding the quantity and quality of meat associated with different skeletal elements, there is a predominance in the number of bones associated with low and medium value meat in the refuse. The elements with medium- and low-value meat are most typical of cattle $(\mathrm{B}=43.6 \% ; \mathrm{C}=37.9 \%)$ and caprines $(\mathrm{B}=10.0 \% ; \mathrm{C}=75.0 \%)^{14}$. The elements bearing high beef portions such as backbone, shoulder and thigh bones (A category) occur in $18.5 \%$ by cattle and $15.0 \%$ by caprines. A similar pattern is recorded in the group of non-identifiable large mammals. On the other hand, pigs are mostly represented by elements with medium meat value $(\mathrm{B}=73.8 \%)$. The high quality pork adds another portion $(\mathrm{A}=11.9 \%)$, while meatless elements make up only $(\mathrm{C}=14.3 \%)$. These differences are indicative of the use of animals. Pigs were mostly kept for meat (and fat) production in the village. However, the assortment of elements may also indicate some cultural practices, such as meat distribution along the village or the food preferences. The spatial distribution of bones cannot be really investigated in this study due to the limited excavation area and small sample size. However, there are some indicators for disposal habits in relation to the presumed function of the settlement features. The skeletal elements of all species grouped according to the meat value clearly show that the habitation space of a hut and the storage pits yielded mainly remains of meaty carcass parts (all species considered together in Fig. 13). On the other hand, the largest portion of primary butchery refuse had been deposited in the waste pits. Other features such as a single pit in front of the oven, five clay extraction pits and ten non-specific pits yielded bones predominantly representing the meaty parts of the skeleton.

A similar pattern of skeletal element representation, including the dominance of ribs and mandibles, has been recorded in other large assemblages dated to the Roman period. At Nitra-Chrenová (Fabiš 2003) cattle was represented mainly by ribs, tibiae, mandible, and scapula fragments, while in pig ribs and mandibles prevailed. At BratislavaTrnávka (sub-assemblages A + B; Šefčáková 2011) cattle and pig elements included mostly mandible, maxilla and phalanges. Compared to the smaller assemblages, for instance coming from a single pit (e.g. Trnava-Horné pole-Bielichová 2017), the representation is different and the studied assemblage contain elements of all body parts of the main livestock. To avoid the problem caused by differential fragmentation, the weight of identifiable specimens (WISP)

\footnotetext{
${ }^{14}$ According to H.-P. Uerpmann $(1973,316)$ the high value meat (A category elements) is attached to the vertebral column (excluding tail), upper leg bones, and bones of the shoulder and the pelvic girdle. Medium value meat (B category) relates to the lower leg bones and skull (with brain and jaw musculature) and mandible (jaw musculature and tongue), ribs and sternum. Lowest meat value ( $\mathrm{C}$ category) is attached to the face bones, tail, and feet (including ankle joints).
} 


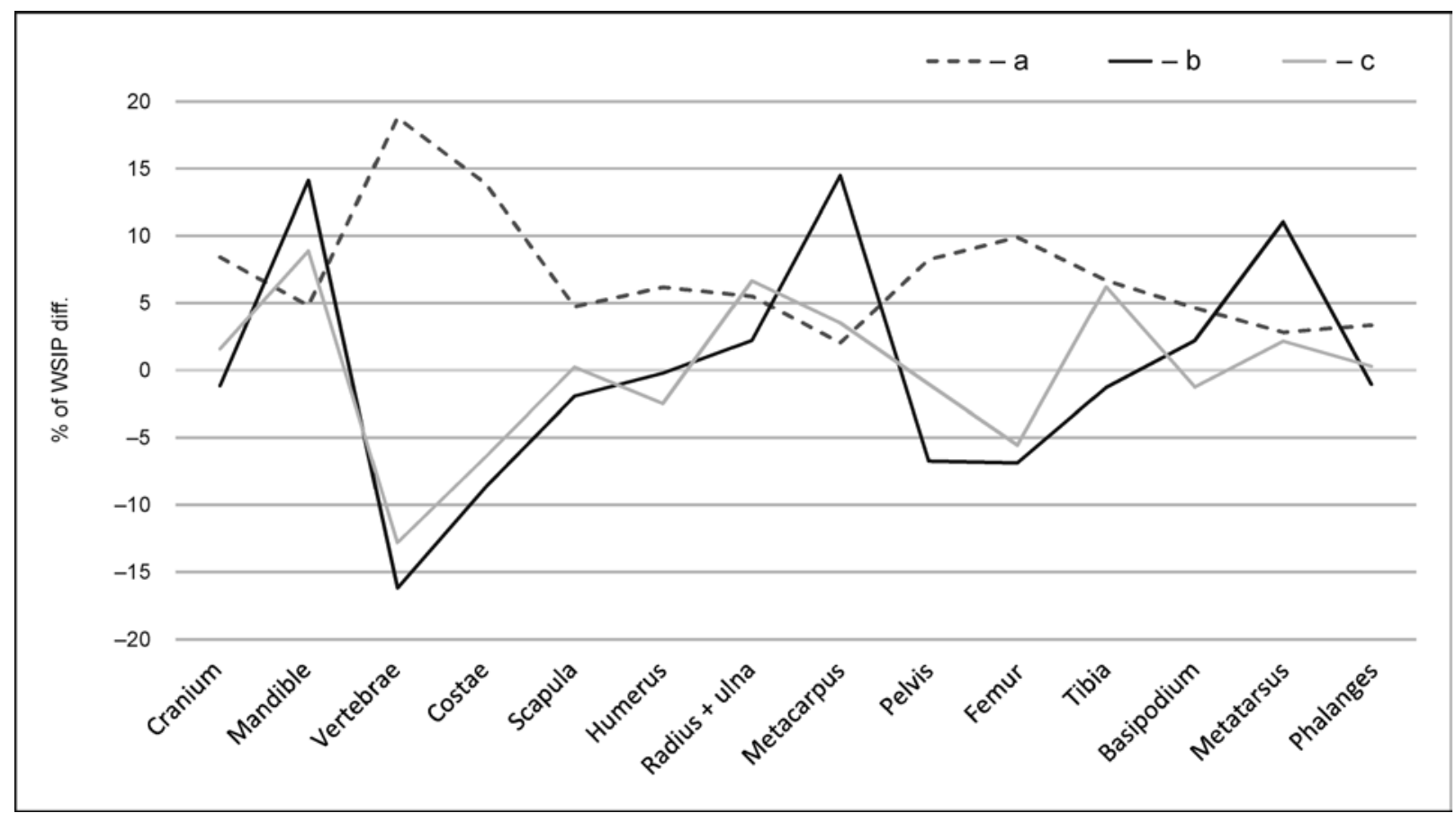

Fig. 14. The representation of skeletal elements of cattle (Bos taurus) in the studied assemblage (Tab. A3) and Nitra-Chrenová (Fabiš 2003). Quantified after weight of identified specimens (WISP) and the difference to the reference individual values (Kunst 2002). Legend: a - reference individual; b - Vel'ké Zálužie; c - Nitra-Chrenová.

was used instead of NISP in this comparison. The weight difference method assesses the representation of cattle skeletal elements at Vel'ké Zálužie and Nitra-Chrenová (Fabiš 2003, 115, tab. 12b) and compares it to the reference individual (Fig. 14; Tab. A3). In contrast to NISP results commented above, this method revealed a significant under-representation of ribs. As far as the mandible is concerned, this method confirmed their large over-representation in the assemblage. Together with mandibulae, the metapodials and somewhat radius with ulna were also over-represented. Vertebrae were the most significantly under-represented in the collection. Although there are rib fragments and single vertebrae available in the group of unidentified large mammal bones, it is only partly explanation for their distinctive under-representation at Vel'ké Zálužie. In contrast to metapodials, basipodium or mandibulae, these elements bear the best quality meat and perhaps were most intensively butchered, prepared as human food and subsequently thrown to dogs, which limited their survival and exacerbated post-mortem disturbances. Problems with the precise identification of ribs and vertebrae may have contributed to their under-representation. As already suggested by NISP, the under-represented were also femur and pelvis which bear the high value meat. Comparing the recorded pattern to the situation at Nitra-Chrenová, similarities in the representation of particular elements are obvious. There is also a significant under-representation of ribs, vertebrae and femur in terms of WISP. In contrast to Vel'ké Zálužie, however, the metapodials were only slightly over-represented. The other elements reflect their natural weight distribution within the complete reference skeleton. We presume that rather than anthropogenic or cultural factors the differences are caused by the large number of specimens available from Nitra-Chrenová.

Horse is represented in the assemblage by elements providing both high- (scapula) as well as the low-value meat (phalanx 3). The same applies to $\mathrm{dog}$, whose meaty (vertebra, radius) as well as meatless elements (metacarpus) were present. Regarding red deer $(\mathrm{MNI}=4)$, approximately $66 \%$ of NISP comprises of elements bearing medium- and high-value meat. This variability also stems from the partially preserved individual deposited in pit 54 , whose remains included elements indicated in Fig. 15. The details on age and modifications will be discussed in the next chapter. There were no butchery marks recorded, just perimortal fractures and a few traces of carnivore gnawing (teeth punctures) on the humerus, innominate, metapodials, scapula and a cervical vertebra. The second immature individual was represented by part of the right hindlimb including the distal part of the tibia, and the completely preserved talus, calcaneus and 


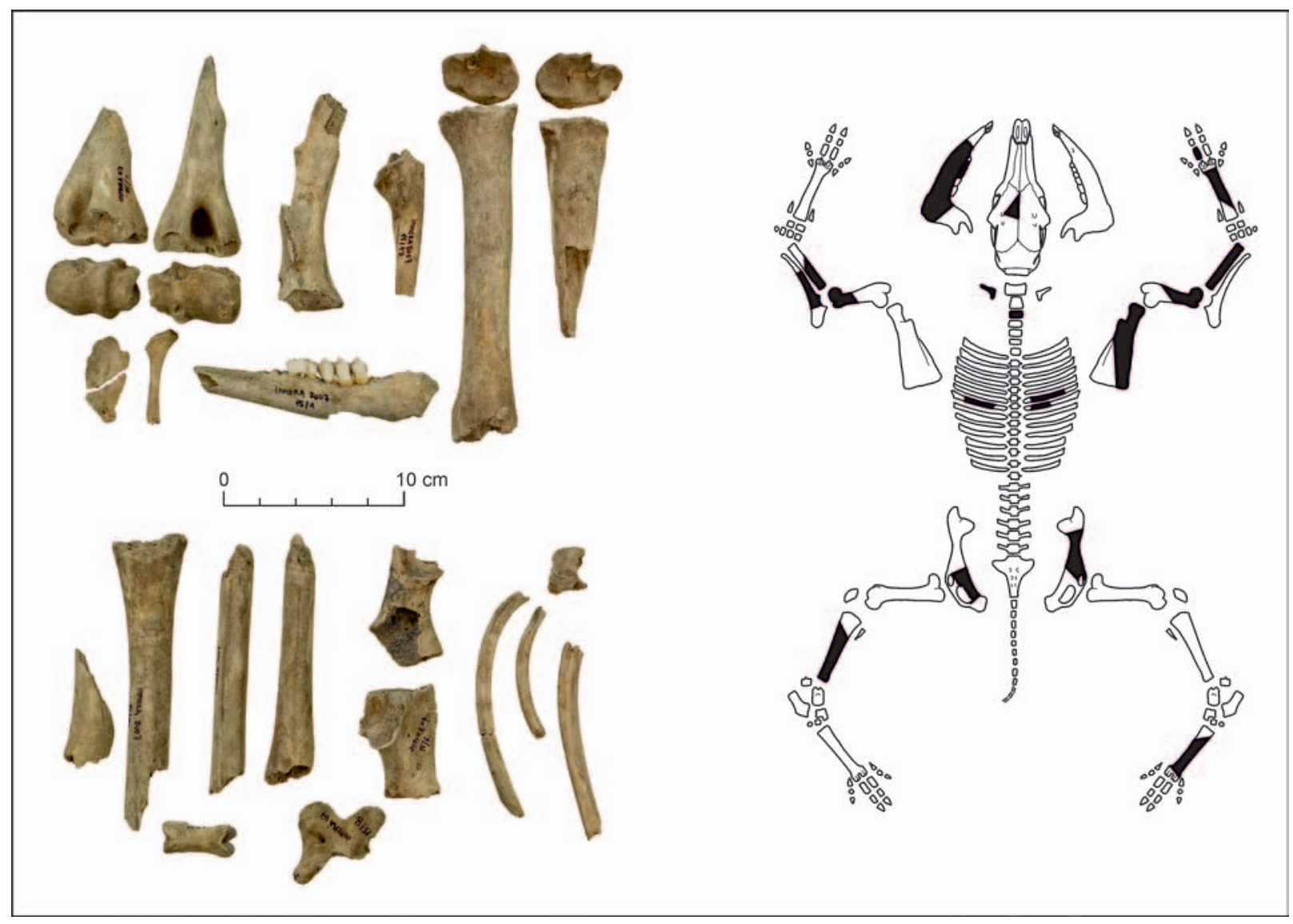

Fig. 15. Vel'ké Zálužie-Ďuriho sad. Feature 54. Skeletal element representation of immature red deer (Cervus elaphus) individual.

centrotarsale. These remains were found together in the pit 50 and represent meatless part of the carcass, perhaps refuse from the primary butchering. The tibia which showed some clear post-mortem (fresh) fractures had the adjoining fragment recovered from pit 58 which suggests either contemporaneous use of both pits or post-recovery bias. The other deer individuals are represented by antler (feature 15 , see above), two metatarsal fragments (feature 30) and a partly preserved axis (feature 5). A small fragment of roe deer metatarsal bone represents a meatless body region.

\section{Husbandry practices: the age and sex of animals}

In a rural economy, females are expected to prevail in the living herd. They are economically more valuable than males which are not producing either offspring or milk. In the 'production sites' the multi-purpose use of cattle and caprines is expected (e.g. Uerpmann 1973). On the other hand, pigs are primarily kept for meat and fat, and in this type of economy they tend to be slaughtered earlier (the ideal culling age is 1.5 year). Male pigs may be overrepresented or equally represented in the cull. The wide range of age classes recorded in all three domesticates suggests their local keeping and the aforementioned multi-purpose use of cattle and caprines (Tab. A4). At least 240 specimens could be aged with more-or-less precision. The best represented age cohort was that of subadult/ adult animals ( $66.7 \%$ of NISP), although only half of them (30.4\%) could be safely identified as adults. A similar portion of bones represented immature animals (33.3\%), of which nearly half belonged to very young individuals - categories 'neonatal' and 'very juvenile'. This general picture therefore supports the idea of the multi-purpose exploitation of domesticates. Additional efforts in sexing and ageing of available material, however, helped to shed light on the culling strategies of particular species and the food production at the site.

In cattle, the size and shape of horn-cores and metapodials provided some clues to sex determination. A completely preserved horn-core (specimen 7/1; Fig. 6:3) has small dimensions, slightly oval 


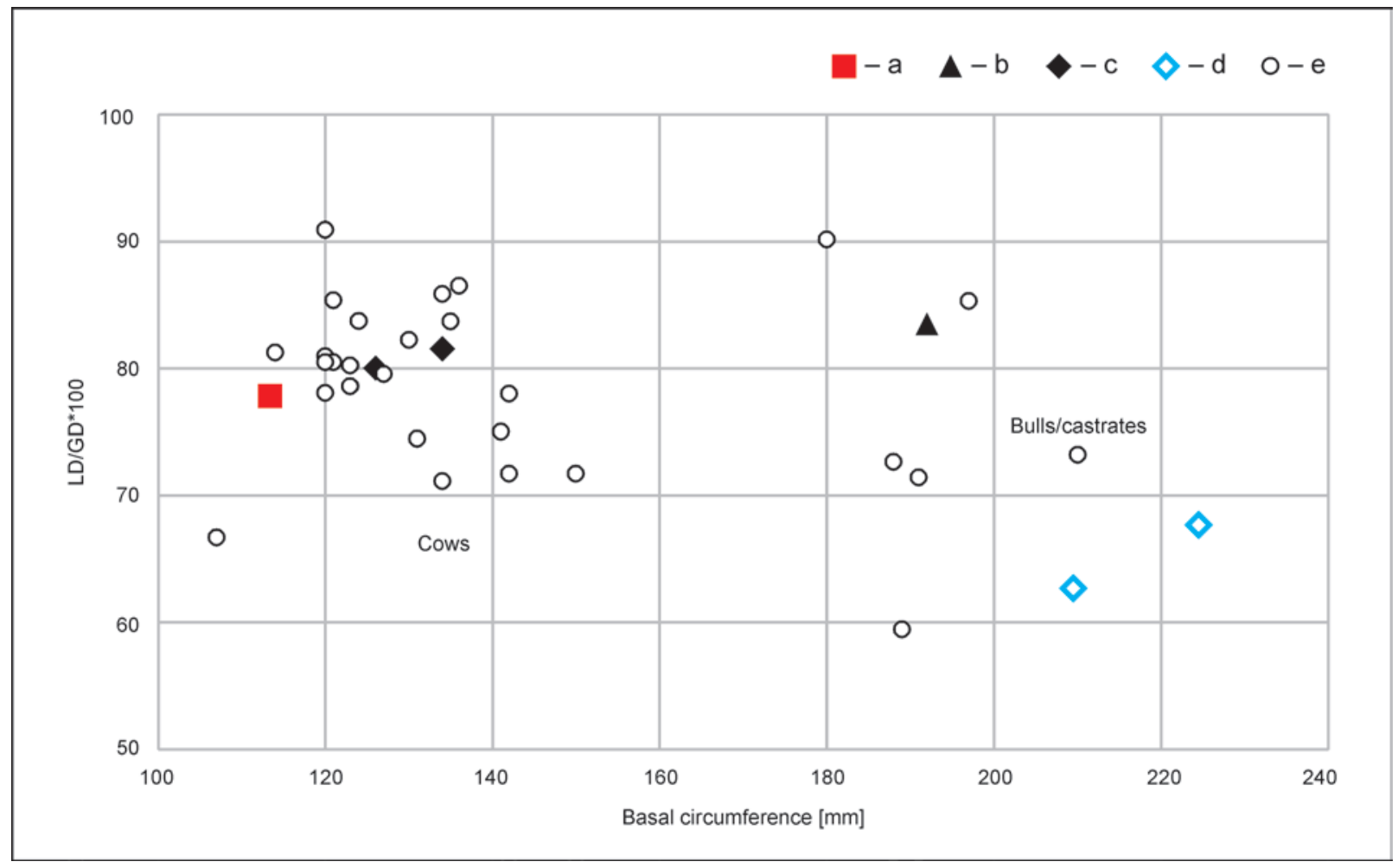

Fig. 16. A scatter plot of cattle horn-core finds from the Roman period sites in southwestern Slovakia. Legend: a - Vel'ké Zálužie (Tab. A7); b - Nitra-Chrenová (Fabiš 2003); c - Vel'ký Meder (Fabiš 1980); d - Nickelsdorf (Riedel 2004); e - CíferPác (Ambros 1977a; 1977b). Abbreviations: LD - least diameter of the horn-core base (M46); GD - greatest diameter of the horn-core base (M45 after A. von den Driesch 1976).

diameter and small curvature. Its porous surface suggests that the individual was not fully grown when slaughtered (subadultus?). The studied site did not yield other cattle horn-cores, so it is impossible to make an intra-population comparison. However, on the basis of small dimensions, we presumed that the horn represents a female individual. The comparison of basal circumferences of available cattle horn-cores from Roman period sites support this assumption (Fig. 16). There are two clearly separated clusters: the first (in the left of the diagram) which represents the small-horned, most probably female individuals and the second one representing the large-horned cattle, most possibly males or castrates. According to the data available from Roman period sites, the basal circumference of female horn-cores ranges between 107 to $150 \mathrm{~mm}$. In the group of the putative cows the values also vary which indicates large heterogeneity of cattle and possible existence of several regional forms. The specimen from Vel'ké Zálužie correlates with the group of small-horned females, although its flatness index reach 77.8 which points to a slightly oval cross-section of the horn, a feature pronounced in males or castrates (Armitage/Clutton-Brock 1976). Nevretheless, presumed male/castrated individuals are distinctively separated in the diagram (Fig. 16) by their basal circumference that ranges from 180 to $210 \mathrm{~mm}$. Cattle with very big horn-cores occurred at Nitra-Chrenová or Cífer-Pác, one of them even reaching the size of the Roman oxen from villa rustica at Nickelsdorf (Fig. 16; Riedel 2004). The specimen from Vel'ké Zálužie with its basal circumference $113.4 \mathrm{~mm}$ represents the second smallest specimen within the group of cattle horn-cores from Roman period sites. It is much smaller than the average of cows from Cífer-Pác $(128 \mathrm{~mm}$; BielichoválAmbros, forthcoming) or cows of the 'small form' cattle from Bernhardstahl (123.9 mm; Riedel 1996, 67, 68, tab. 7). Therefore, it support aforementioned assumption on subadult age of the individual.

Additional information on the sex of culled cattle was provided by five well preserved metapodials. The relation of the length and width-length ratio was initially compared to the medieval dataset published by B. Novotný (1966) and enabled to recognize two males and three females (Tab. 9). However, like with the single horn-core, metric data from Roman period sites were assembled to sex the metapodials within the contemporaneous context (Fig. 17; 18). It is known that "the horn-cores and pelvic bones are secondary sexual characteristics but those on metapodia 


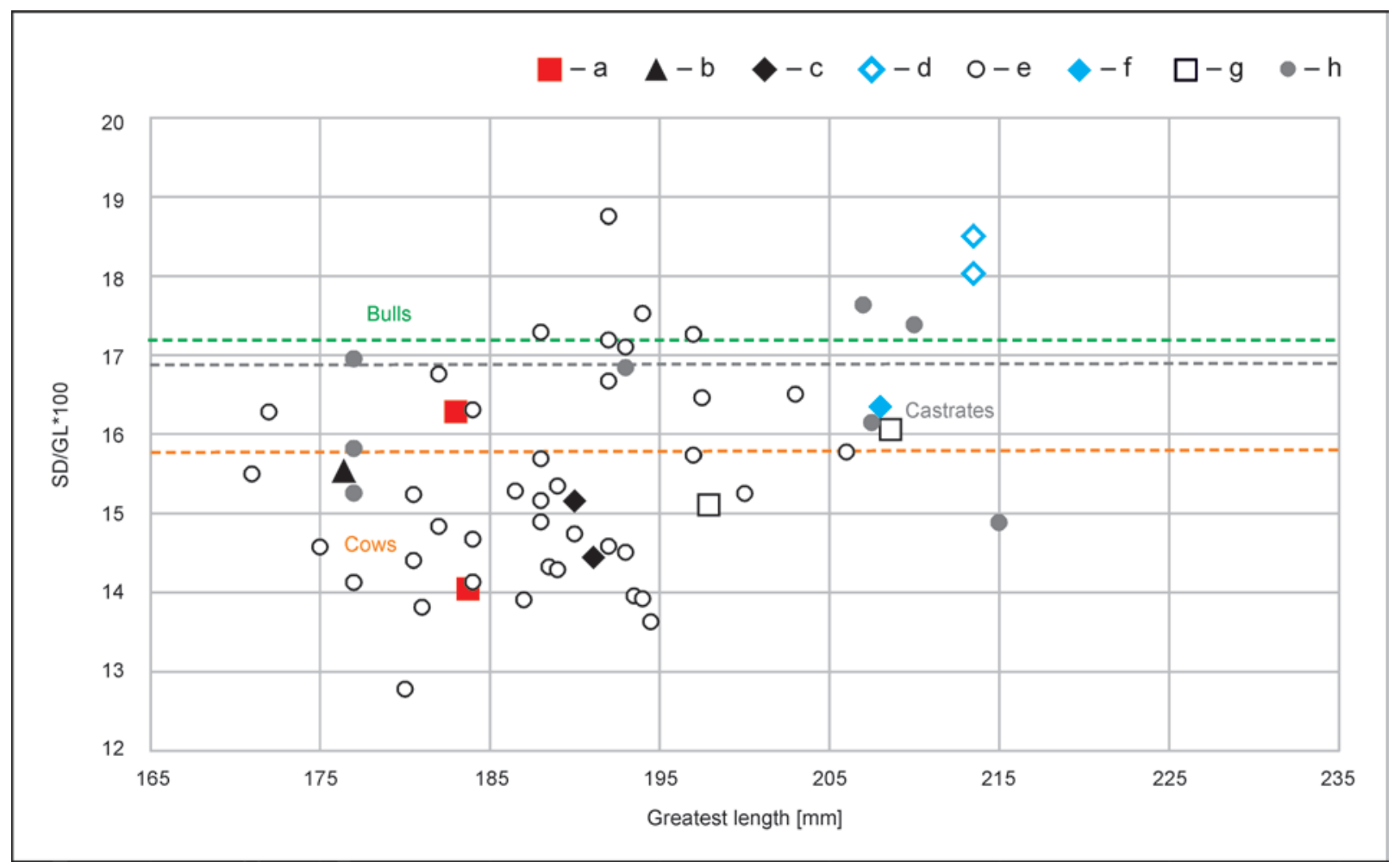

Fig. 17. A scatter plot of the metacarpal bones of cattle from the Roman period sites in southwestern Slovakia. Orange dashed line (15.80) refer to average cow; grey line (16.90) to average castrate and green line (18.24) to average bull from Tác-Gorsium (after Bökönyi 1984, 36). Legend: a - Vel'ké Zálužie (Tab. A7); b - Nitra-Chrenová (Fabiš 2003); c - Vel'ký Meder (Fabiš 1980); d - Nickelsdorf (Riedel 2004); e - Cífer-Pác (Ambros 1977b); f - Iža (Ambros 1991); g - Trnava-Horné pole (Bielichová 2017); h - Štúrovo (Ambros 1984). Abbreviations: SD - smallest breadth of the diaphysis; GL - greatest length.

are tertiary. Their size is related to the greater body weight of males and the sexual dimorphism manifest later in age which makes sexing metapodials extremely difficult." (Uerpmann 1973, 314). Therefore, we must bear in mind that, without possibility of ageing the compared specimens, it is also possible that subadult individuals (aged from 2 to 4 years) were included. Sexual dimorphism is still developing at that age.

Age differences and the possible admixture of various cattle forms, attested at Roman period sites in the wider region (e.g. Bökönyi 1974; 1984; Pucher 2016) may complicate the final sex-determination of our finds.

The metacarpals of Roman period cattle vary in gracility and total length, although they did not form clearly separated clusters (Fig. 17). Specimen 32/1 from Vel'ké Zálužie most probably belonged to a female $(\mathrm{GL}=183.7 \mathrm{~mm}$; index $=14)$ and specimen $19 / 6$ to a male cattle $(\mathrm{GL}=183 \mathrm{~mm}$; index is 16.3). In general, robust animals with higher index values are presumably males and the more gracile individuals showing smaller values, are likely to represent females. However, as is clear from the diagram, there are many specimens that show intermediate values. Opposite to females, there are metacarpals of castrated individuals which are significantly longer and show intermediate slenderness index values. The distinctive robustness and size of two Roman oxen from Nickelsdorf is clearly illustrated by their far right position in the diagram. The distribution of metacarpal dimensions also offers evidence that some very large and robust males/castrates were slaughtered on Germanic sites in present day Slovakia, for example at Štúrovo. This difference may alternatively be explained - by a different culling strategy and cattle exploitation working oxen slaughtered or keeping of larger form of cattle. Bearing in mind the size of Roman cattle (in the diagram represented by oxen from Nickelsdorf and the individual from Iža; Fig. 17), it may be assumed large cattle (oxen?) were also kept also in Germanic settlements in Trnava and Cífer-Pác (but not at Štúrovo) In order to compare cattle from the territory of the Barbaricum (southwestern Slovakia) and adjacent areas under the influence of the Roman Empire (Pannonia), data from the Roman town Tác-Gorsium have been added to the diagram (Bökönyi 1984; 28, 36, tab. 7). It has been assumed that improved animals imported from Italy contributed a substantial portion to beef supplies in that city. 


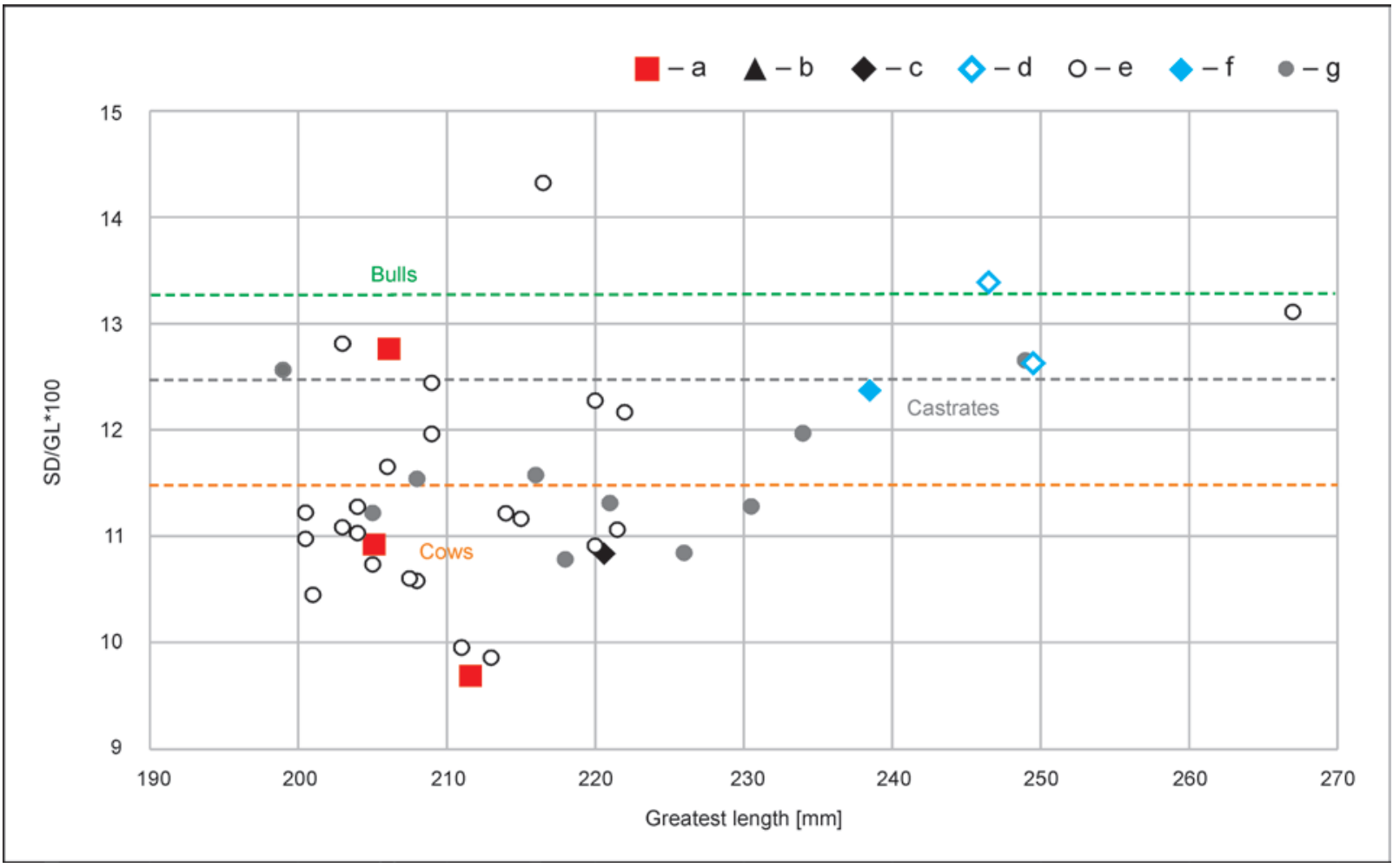

Fig. 18. A scatter plot of the metatarsal bones of cattle from the Roman period sites in southwestern Slovakia. Orange dashed line (11.46) refer to average cow, grey line (12.47) to average castrate and green line (13.27) to average bull from Tác-Gorsium (after Bökönyi 1984, 36). Legend: a - Vel'ké Zálužie (Tab. A7); b - Nitra-Chrenová (Fabiš 2003); c - Vel'ký Meder (Fabiš 1980); d - Nickelsdorf (Riedel 2004); e - Cífer-Pác (Ambros 1977b); f - Iža (Ambros 1991); g - Štúrovo (Ambros 1984). Abbreviations: SD - smallest breadth of the diaphysis; GL - greatest length.

Compared to them, bones from Vel'ké Zálužie represented significantly more gracile animals. A similar variability can be seen in metatarsal measurements (Fig. 18). Two of three specimens from Vel'ké Zálužie, showing smaller dimensions most probably represent females of different sizes. The third specimen $22 / 10$ is more robust and possibly belonged to a male (Tab. 9). Like in the case of metacarpals, the average slenderness indices of metatarsals from the Roman town Tác-Gorsium (indicated by dashed lines in the diagram), illustrate the smaller size of Germanic cattle in both sexes. On the other hand, rather large animals can be found at Germanic settlements, either located along the Danubian Limes (Štúrovo) or further north (Cífer-Pác). The latter settlement provided a few examples of extraordinary large and robust individuals (two empty dots in the upper right section of the diagram; Fig. 18). The $268 \mathrm{~mm}$ long specimen ${ }^{15}$ exceeds the values recorded for the Nickelsdorf oxen.

At Vel'ké Zálužie, but also in other Germanic sites, the sexing of metapodials suggested the over-representation of females in the cull which is in accordance with expected rural economy, where cows are most important to maintain the herd reproduction and producing the milk. Results also supported the idea of slaughtering (exporting?) the male offspring before reaching adulthood, or castration due to the bad temper and aimed at producing working oxen. Nearly all sites considered in the diagrams showed this trend, although more male/ castrated cattle is noticeable in Štúrovo or Cífer-Pác. This may indicate the higher status of inhabitants (wealth), imports of animals due to higher demand, different slaughter strategy or greater size variability within the living herd.

Although limited, absolute ageing of cattle adds further evidence on the use of animals at the studied site. Dental data (Tab. A5) suggested that at least three individuals were slaughtered very early, before reaching an ideal age for the meat production, i.e. before $2.5-3.5$ year of life. Two younger calves (mandible 28/18 and 29/1) died at age of 2-4 months and older one (mandible 30/2) in its $4^{\text {th }}-6^{\text {th }}$ month. A single adult individual (mandible 20/10-11) with moderately worn permanent dentition attested the

15 This find should be re-measured in the deposit. 


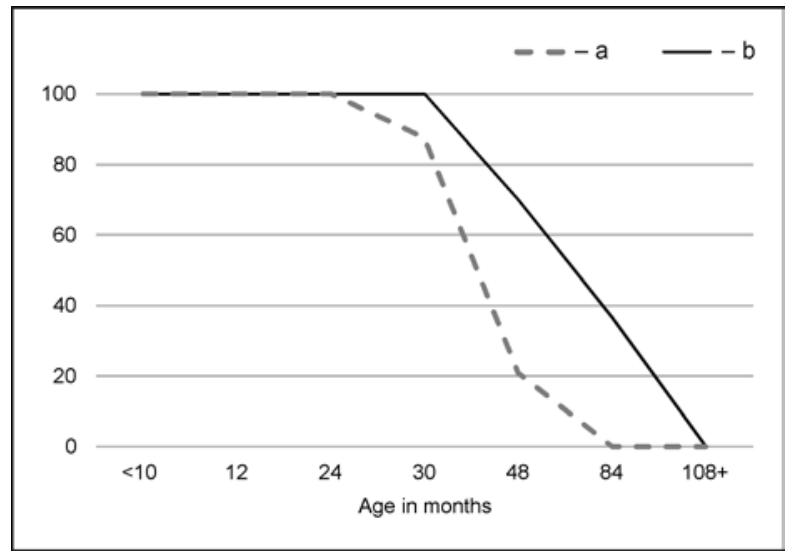

Fig. 19. The relative survivorship of cattle from the Roman period settlements in Vel'ké Zálužie (Tab. A6) and NitraChrenová (Fabiš 2003). Quantified after NISP. Legend: a - Vel'ké Zálužie; b - Nitra-Chrenová.

death above the $4^{\text {th }}$ year (category E in Peške 1994). Additional data on age at slaughter in cattle were provided by the state of epiphyseal fusion (Tab. A6). According to them, cattle were killed in their $2^{\text {nd }}$ and 2.5 year, but mostly before reaching the adulthood (between $3.5-4^{\text {th }}$ year). Thus, in contrast to general results presented above, absolute ageing points to the predominance of immature cattle within the assemblage and slaughter of individuals in their ideal age for the meat production (2-4 years). Such results are in contradiction with the culling strategy assumed for cattle from Nitra-Chrenová, where, according to the epiphyseal data, animals were killed later in their age. Figure 19 shows a significantly larger portion of animals surviving the adulthood in here (cattle above $4^{\text {th }}$ year in Nitra $=70 \%$; in Vel'ké Zálužie $=20.8 \%$ of NISP) and maturity (around 7 years old in Nitra $=36.7 \%$; not recorded in Vel'ké Zálužie). Although the calves' slaughtering in NitraChrenová has been also documented (a single individual in 5-6 months; Fabiš 2003, 107), the predominance of adult and mature individuals was attested through dental ageing, therefore focus on milk and labour exploitation assumed (Fabiš 2003, 108). The sample size of both Roman period settlements is far from representative, however, the combination of sex and age data, at least for particular areas explored, indicated different husbandry strategies and/or slaughtering of cattle. In Vel'ké Zálužie, the exploitation of younger animals is approved if meat production concerns. The milk production, on the other hand, can be proposed on the basis of higher presentation of calves in the cull.

Regarding other domestic species kept at the site, the information is even more limited. Sexing pigs on the basis of canine teeth indicated the predominance of males in the cull (12: 2 by NISP).
The dental data suggest that three individuals were killed between 0.5 and 1 year (category D and E; Tab. A5) and two others, showing partially abraded third molars, shortly after reaching $2^{\text {nd }}$ year (category $\mathrm{H}$ and I). The epiphyseal data indicated a survival of early juvenile pigs and the slaughter between 1 and 2.5 years, i.e. at most ideal time for the meat production (Tab. A6). These data are in accordance with relative ageing that showed higher representation of juveniles and subadult pigs in the cull (Tab. A4). A similar age and sex of the pigs were reported at other Germanic settlements. In NitraChrenová for instance, the slight overrepresentation of males and the absence of earliest age categories was recorded. Most pigs were killed here between 1.5-2.5 years and so just some animals survived until the adulthood and maintain the reproduction (Fabiš 2003, 110).

In caprines the sex was not securely determined. A single sheep horn-core was relatively long, but gracile and nearly circular in the cross section. Its small dimensions, compact surface and developed curvature suggest it belonged to an adult female. Regrettably, there are very few regional data for comparisons of sheep horn core morphology, so the sex determination stays tentative only. In three sheep specimens from the Roman military settlement at Iža, a basal circumference of the sheep horn-cores ranged from 149 to $167 \mathrm{~mm}$, its least diameter from 36 to 44 and largest diameter from 50 to $60 \mathrm{~mm}$. A single horn-core from Cífer-Pác had the basal circumference of $158 \mathrm{~mm}$, smaller diameter of $42 \mathrm{~mm}$ and larger diameter of $55 \mathrm{~mm}$. So these animals had much bigger horns in comparison to our specimen. The relative ageing data revealed little information for caprines, although the presence of variety of classes can be observed (Tab. A4). This suggest the local keeping/breeding of sheep (goats). The dental data attested the slaughter in 6 months (specimen 16/11) and between 0.5 and 1 year (specimen 31/2). Two other individuals were killed between 2 and 4 year (Tab. A5). The epiphyseal data, on the other side evidence survival of juvenile and subadult animals (above 3 year) as well as killing young (before 3 year; Tab. A6). So animals in 1-2 year or the most ideal age for meat exploitation (Uerpmann 1973, 316), seems to be the least represented in the assemblage. A similar pattern, but attested on larger sample size, has been noted at Nitra-Chrenová. The majority of caprines died before and after this age category which was interpreted as focus on exploitation of the secondary products - wool $/ \mathrm{milk}$. The possible seasonal surplus of male offspring that could be sell elsewhere (export) was hypothetised too (Fabiš 2003, 109). 
Concerning dog bones from Vel'ké Zálužie, the fused distal epiphyses of a radius and fused vertebral apophyses point to fact that animal died was an adult (pet, working dog naturally died?). The size and porous character of the bones surface in horse specimens, on the other hand, indicated that one of two presented individuals may have died still immature (naturally or killed intentionaly). The missing dental or epiphyseal data complicated further interpretation of horse and dog remains. The site revealed a relatively large portion of red deer individuals $(\mathrm{MNI}=4)$ in different age - at least two of them still immature at death. The first one, represented by articulated heel bones, belonged to a subadult and according to the unfused epiphysis of distal tibia and tuber calcanei it was killed between first and second year of life (deposited in pit 50). The partially preserved red deer skeleton (deposited in pit 54) represents an even younger animal. The state of milk dentition and epiphyseal fusion shows that fawn deer was killed between $3^{\text {rd }}$ and $4^{\text {th }}$ month. If the animal was born in MayJune, when a standard calving season of the European red deer is reported (Komárek/Štěrba/Fejfar 2001), it died or was killed during the late summer or autumn, i.e. in August-October same year. Very young age of red deers and preservation of partial skeletons evoke the idea of keeping deers alive at (or near) the site, but there is no hard evidence on such speculation. Most probably, all deer remains represent the hunted animals killed by man in order to obtain meat. Further two red deers died as subadult or adults. The roe deer specimen belonged also to the subadult/adult individual.

\section{Livestock body size and shape}

The assemblage yielded a small collection of measurable bones that provided few indicators on animals' morphology (Tab. A7). Largest amount of data concerns cattle whose completely preserved metapodials and tali represent valuable size indicators (e.g. Albarella 2002; Davis et al. 2012). The previous research on the Roman period husbandry suggested that there were two morphologically distinctive populations of cattle present in Pannonia: the brachyceros with short horns and withers height of $100-120 \mathrm{~cm}$, and improved Italian, the primigenius type with long horns and withers height of 120-140 cm (Bökönyi 1974). For instance, the average withers height of cattle from Tác-Gorsium points was $125.9 \mathrm{~cm}$ (range of 104.6-143) based on metacarpals and $126.8 \mathrm{~cm}(107.4-143.3)$ based on metatarsals. It has been assumed that "cattle exceeding $125 \mathrm{~cm}$ in withers height can be considered improved Italian breed" (Bökönyi 1984, 28). In another Roman settlement, in villa rustica at Nickelsdorf, the imports of cattle from central Italy was argued on the basis of analysis of two complete oxen skeletons (Pucher 2006). Their withers height was approximately $134 \mathrm{~cm}$ with the body mass of 550 to $630 \mathrm{~kg}$. Moreover, in Germanic Bernhardstahl a profound morphometric study revealed the hybridization of aforementioned populations and possible existence of new, mid-sized cattle 'breed' or type (Pucher 2016; Riedel 1996). In the eastern Austria, the coexistence of different cattle has been presumed already from the Late Iron Age (Pucher/Saliari/Ramsl 2015). Similar to other 'inovations', it was hypothetised that observed size changes of cattle or sheep were related to the Romans and their economic and/or cultural influence within the region (see also Bielichová 2017; Fabiš/Bielichová 2014; Šefčáková 2011).

At Vel'ké Zálužie, limited number of measurable elements do not allow to reveal complete picture of the local cattle variability. Considering the head, a single well preserved horn-core of subadult female suggest keeping of the short-horned, perhaps small sized cattle which is in accordance with majority of finds from the Middle Danube area (e.g. Bökönyi 1974; 1984; Pucher 1999). The horn-core (specimen 7/1; Fig. $21: 1$ ) is short, relatively robust and compact, slightly flattened in the cross-section with the small basal circumference (see previous chapter and Fig. 16). Regrettably, other finds that would help us to shed more light on the head morphology of local cattle are not available. On the other side, the assemblage provided complete metapodials that enable the calculation of the withers height of at least here individuals (Tab. 9). According to Matolcsi coefficients the average withers height of cattle was $113.7 \mathrm{~cm}$. By metacarpals it was $113.3 \mathrm{~cm}$ (range of 110.4-116.3) and by metatarsals $113.9 \mathrm{~cm}$ (109.3-119.1). If our determination of sex is considered, the average withers height of female was $110.9 \mathrm{~cm}(109.3-112.7)$ and $115.9 \mathrm{~cm}$ of male (115.8-116). If Calkin's coefficients are used, the average withers height of cattle was very similar and made $113 \mathrm{~cm}$. By metacarpals it was $112.2 \mathrm{~cm}(109.4-114.6)$ and by metatarsals $113.6 \mathrm{~cm}$ (109.5-118.1). The average height of females was $110.8 \mathrm{~cm}(109.5-113)$ and of males $114.6 \mathrm{~cm}$ (114.2-115). Combining results of both methods, the average withers height of cattle was $113.4 \mathrm{~cm}$, where females had $110.9 \mathrm{~cm}$ and males $115.3 \mathrm{~cm}$ in the withers. These results again points to the small-bodied 'breed' of cattle. According to the body mass indices (Vigne 1991) and reduction suggested for primitive breeds (Kysely 2016), the local cattle from in average $350 \mathrm{~kg}$ of live weight - in females $333 \mathrm{~kg}$, males $367 \mathrm{~kg}$. The meat and work utility of such small cattle was small, but it might had been 
Tab. 9. Vel'ké Zálužie-Ďuriho sad. Sex and size of cattle according to the metapodials. Abbreviations: GL - greatest length; Bp - (greatest) breadth of the proximal end; SD - smallest breadth of the diaphysis; Bd - (greatest) breadth of the distal end; WRH - withers height.

\begin{tabular}{|c|c|c|c|c|c|c|c|c|c|c|c|c|c|c|c|c|}
\hline \multirow{2}{*}{ 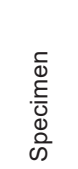 } & \multirow{2}{*}{ 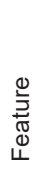 } & \multirow[b]{2}{*}{$\frac{0}{i n}$} & \multirow{2}{*}{ 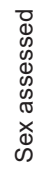 } & \multirow[b]{2}{*}{$\overrightarrow{0}$} & \multirow[b]{2}{*}{ ๓ి } & \multirow[b]{2}{*}{ 号 } & \multirow[b]{2}{*}{ రㅁ } & \multirow{2}{*}{ 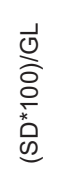 } & \multirow{2}{*}{ 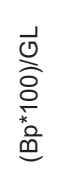 } & \multirow{2}{*}{$\begin{array}{l}\frac{1}{0} \\
\stackrel{0}{O} \\
\frac{0}{0} \\
\stackrel{0}{0} \\
\underline{0}\end{array}$} & \multicolumn{3}{|c|}{ WRH (Matolcsi 1970) } & \multicolumn{3}{|c|}{ WRH (Calkin 1960) } \\
\hline & & & & & & & & & & & Cow & Bull & Ox & Cow & Bull & Ox \\
\hline \multicolumn{17}{|c|}{ Metacarpus } \\
\hline $19 / 6$ & 10 & d & $\mathrm{m}$ & 183.0 & 52.5 & 29.8 & 52.3 & 16.3 & 28.7 & 28.6 & 110.4 & 115.8 & 113.0 & 109.4 & 114.2 & 112.2 \\
\hline $19 / 7$ & 10 & d & ? & - & 50.5 & 28.1 & - & - & - & - & - & - & - & - & - & - \\
\hline $23 / 3$ & 9 & d & ? & - & - & - & 55.8 & - & - & - & - & - & - & - & - & - \\
\hline $23 / 4$ & 9 & $\mathrm{~s}$ & ? & - & - & - & 61.2 & - & - & - & - & - & - & - & - & - \\
\hline $32 / 1$ & 9 & d & $f$ & 183.7 & 52.1 & 25.8 & 51.2 & 14.1 & 28.4 & 27.9 & 110.8 & 116.3 & 113.4 & 109.9 & 114.6 & 112.6 \\
\hline \multicolumn{17}{|c|}{ Metatarsus } \\
\hline $12 / 1$ & 6 & d & $f$ & 211.6 & 39.6 & 20.5 & 45.6 & 9.7 & 18.7 & 21.6 & 112.7 & 119.1 & 116.5 & 113.0 & 118.1 & 116.2 \\
\hline $22 / 9$ & 8 & $d$ & $f$ & 205.1 & - & 22.4 & 47.8 & 10.9 & - & 23.4 & 109.3 & 115.4 & 112.9 & 109.5 & 114.5 & 112.6 \\
\hline $22 / 10$ & 8 & $\mathrm{~s}$ & $\mathrm{~m}$ & 206.1 & 45.7 & 26.3 & - & 12.8 & 22.2 & - & 109.8 & 116.0 & 113.5 & 110.1 & 115.0 & 113.2 \\
\hline
\end{tabular}

sufficient if milk production is considered (Strapák et al. 2013). For comparison, a cow of the recent Slovak Simmental breed (slovenský strakatý dobytok) reaches such weight in her first year of life (Strapák et al. 2013; 330, tab. 9.46-9.47). The live weight of modern cattle ranges from 550 to $800 \mathrm{~kg}$ in cows and from 1100 to $1300 \mathrm{~kg}$ in bulls, but in the past, the sexual dimorphism of primitive cattle was decreased due to the isolation and inbreeding (Uerpmann 1973). We may expect that also at Vel'ké Zálužie the differences in the withers height as well as body mass were not large.

The information on the body size/mass of the Roman period cattle from the territory of southwestern Slovakia is scarce and only few sites provided statistically representative data (Tab. 10). Based on the metapodials of unknown sex and new calculations, the average withers height of 'Germanic' cattle was $117.1 \mathrm{~cm}$ which correspondents to the body mass of $382 \mathrm{~kg}$. This is the cattle within the variation range of small-sized breed as suggested by S. Bökönyi (1974; 1984). However, results are changing from site to site. Clearly, some finds of metapodials (e.g. Bratislava-Vajnory, Štúrovo, Trnava, Vel'ký Meder) points to the animals exceeding the range of the small 'Celto-Germanic' cattle. It is evident, that larger cattle occurred in Štúrovo, where sufficient number of metapodials is on disposal. The average withers height of cattle was $120.8 \mathrm{~cm}$ that is around $6 \mathrm{~cm}$ more than at Vel'ké Zálužie. It can be explained by different slaughter and husbandry practices (e.g. larger portion of oxen in the cull; Fig. 17; 18) or the imports of larger 'breed' and hybridization (?). The immediate vicinity of the Roman province would support the latter interpretation, mainly if we look at the 10-12 cm difference in between Štúrovo and other Germanic sites, However, the scarcity of data do not allow the test both hypothesis properly. The representation of solitary individuals with higher withers height was recorded at settlements further north from the Roman Limes, in Trnava or Vel'ký Meder, but those may represent male individuals.

If sex determination is taken into consideration, the calculations provide more specific results. A cattle metacarpal from Nitra-Chrenová points the withers height of $106.4 \mathrm{~cm}(300 \mathrm{~kg})$ in females. The greatest length of metapodials of known sex from Cífer-Pác (Bielichová 2017; BielichoválAmbros, forthcoming). Here the average withers height of cows was $108.9 \mathrm{~cm}$ (with range of 103.6-115.4 cm) and of males $119.8 \mathrm{~cm}(113.6-123.2)$ that correspondent to the live weight of $318 \mathrm{~kg}$ in females (281-368) and $405 \mathrm{~kg}$ in males (354-436). An extremely large metatarsal (Fig. 18; see above) would even point to a male/castrate with the withers height of $147 \mathrm{~cm}$ and the body mass of $700 \mathrm{~kg}$, which is very large cattle reaching the parameters of females of modern breed (see above). If the measurements are correct, this individual may represent either large-sized Italic type of cattle or other wild bovid, for instance aurochs and it must be re-examined. Two sexed metacarpals from Trnava (Bielichová 2017) suggested that rather large individuals - a cow with body size $119.4 \mathrm{~cm}(402 \mathrm{~kg})$ and the castrate with body size $128.8 \mathrm{~cm}(490 \mathrm{~kg})$. Both would be significantly 
Tab. 10. The size of the Roman period cattle according to the metapodials from sites in southwestern Slovakia. Except WRH all measurements in mm. Abbreviations: $\mathrm{n}$ - number of finds; GL - greatest length; Min - minimum; Max - maximum; WRH - withers height. The Matolcsi's coefficients for the metapodials of unknown sex was used in the calculation (Matolcsi 1970). The live weight was calculated after J.-D. Vigne (1991) and its value reduction of $13 \%$ suggested by R. Kyselý (2016).

\begin{tabular}{|c|c|c|c|c|c|}
\hline \multirow{2}{*}{ Site } & \multicolumn{5}{|c|}{ Cattle metapodials } \\
\hline & $\mathrm{n}$ & GL [average] & Min & Max & WRH $[\mathrm{cm}]$ \\
\hline Nitra-Chrenová, Shell, Baumax & 1 & 176.4 & - & - & 109.0 \\
\hline Bratislava-Trnávka, Zadné B & 1 & 182.0 & - & - & 112.5 \\
\hline Vel'ké Zálužie-Ďuriho sad & 2 & 183.4 & 183.0 & 183.7 & 113.4 \\
\hline Bratislava-Trnávka, Zadné A & 1 & 186.0 & - & - & 115.0 \\
\hline Cífer-Pác, Nad mlynom & 39 & 188.4 & 171.0 & 206.0 & 116.5 \\
\hline Vel'ký Meder-Vámostelek & 2 & 190.6 & 190.0 & 191.1 & 117.8 \\
\hline Štúrovo-Military training ground & 8 & 195.4 & 177.0 & 215.0 & 120.8 \\
\hline Trnava-Horné pole & 2 & 203.3 & 197.9 & 208.6 & 125.7 \\
\hline Metacarpus & 56 & 188.2 & 183.8 & 200.9 & 116.3 \\
\hline Vel'ké Zálužie-Ďuriho sad & 3 & 207.6 & 205.1 & 211.6 & 113.7 \\
\hline Bratislava-Trnávka, Zadné A & 1 & 208.0 & - & - & 113.9 \\
\hline Cífer-Pác, Nad mlynom & 24 & 212.5 & 200.5 & 267.0 & 116.4 \\
\hline Bratislava-Trnávka, Zadné B & 5 & 209.2 & 180.0 & 238.0 & 114.6 \\
\hline Štúrovo-Military training ground & 10 & 220.7 & 199.0 & 249.0 & 120.9 \\
\hline Vel'ký Meder-Vámostelek & 1 & 220.6 & - & - & 120.8 \\
\hline Bratislava-Vajnory, Pri Visáku & 1 & 228.0 & - & - & 124.9 \\
\hline Metatarsus & 45 & 215.2 & 196.2 & 241.4 & 117.9 \\
\hline WRH (average; SW Slovakia) & 101 & - & - & - & 117.1 \\
\hline LW (average; SW Slovakia) & 101 & - & - & - & 382 kg \\
\hline
\end{tabular}

larger than what we found at Vel'ké Zálužie or other Germanic sites. In Bruckneudorf, where hybridization and co-existence of several cattle breeds was observed, such castrate would be consider as a cow of the large-sized Italic type of cattle (Pucher 2016; 260, diagram 8).

To retrieve more information on the body size of cattle, the metric data an astragals from the Roman period sites were collected and evaluated (Fig. 20; Tab. 11). A large heterogeneity is shown, without possibility of clustering the finds according to sex or cattle type. The specimens of Vel'ké Zálužie fit to the variation range. Two specimens (28/19 and 23/5) represent significantly larger individuals and may represent male or oxen, while remaining two (16/1 and 28/20) perhaps belonged to females or subadult cattle. The average lateral length (GLl) of tali from Vel'ké Zálužie is $62 \mathrm{~mm}$ with range of $55.3-67.2 \mathrm{~mm}$. Most of the sites where cattle tali were found show similar results. The largest tali in the group belong to Roman oxen from Nickelsdorf and an individual from Štúrovo (GL1 = $72 \mathrm{~mm}$ ). More specimens located in the upper limit
Tab. 11. The size of the Roman period cattle according to the knuckle bones (talus) from sites in southwestern Slovakia. Bone measurements in mm. Abbreviations: $\mathrm{n}$ - number of finds; Min - minimum; Max - maximum; GLl - greatest length of the lateral half; $\mathrm{Dl}$ - depth of the lateral half.

\begin{tabular}{|l|c|c|c|c|}
\hline \multirow{2}{*}{ Site } & \multicolumn{4}{c|}{ Cattle talus } \\
\cline { 2 - 5 } & $\mathrm{n}$ & Mean & Min & Max \\
\hline Vel'ký Meder-Vámostelek & 20 & 61.4 & 54.7 & 68.1 \\
Nitra-Chrenová, Shell, Baumax & 5 & 61.5 & 51.1 & 67.2 \\
Vel'ké Zálužie-Ďuriho sad & 4 & 62.0 & 55.3 & 67.2 \\
Štúrovo-Military training ground & 11 & 63.1 & 52.5 & 72.0 \\
Trnava-Horné pole & 6 & 64.7 & 59.1 & 69.7 \\
\hline GLI & 26 & 62.5 & 54.5 & 68.8 \\
\hline Nitra-Chrenová, Shell, Baumax & 5 & 34.2 & 28.4 & 37.0 \\
Vel'ké Zálužie-Ďuriho sad & 4 & 34.7 & 31.6 & 37.3 \\
Štúrovo-Military training ground & 11 & 35.6 & 29.0 & 41.0 \\
Vel'ký Meder-Vámostelek & 20 & 34.3 & 29.6 & 37.7 \\
Trnava-Horné pole & 6 & 36.0 & 33.2 & 40.0 \\
\hline DI & 41 & 35.0 & 30.4 & 38.6 \\
\hline
\end{tabular}




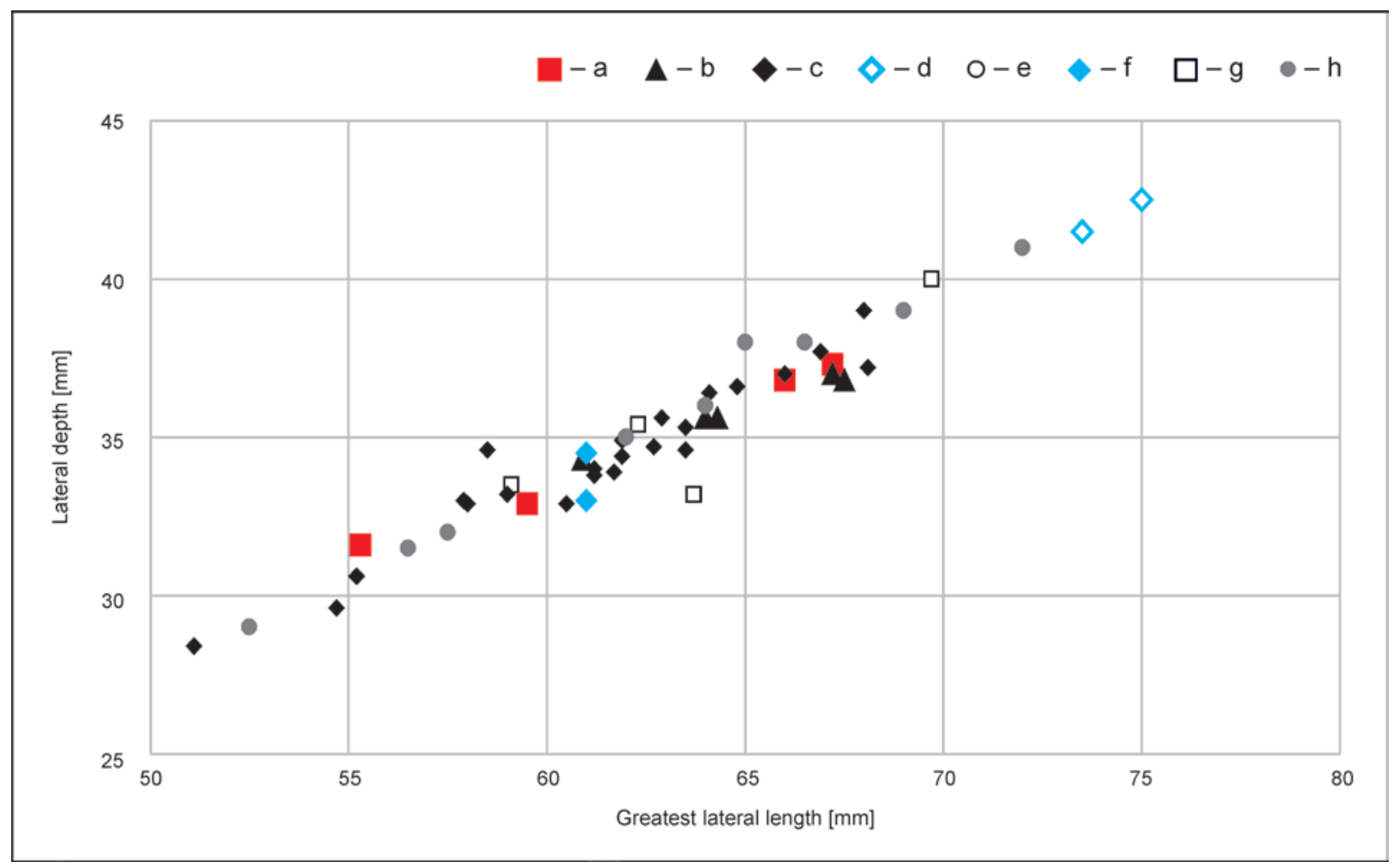

Fig. 20. A scatter plot of knuckle bones (talus) of cattle from the Roman period sites in southwestern Slovakia. Legend: a - Vel'ké Zálužie (Tab. A7); b - Nitra-Chrenová (Fabiš 2003); c - Vel'ký Meder (Fabiš 1980); d - Nickelsdorf (Riedel 2004); e - Cífer-Pác (Ambros 1977b); f - Iža (Ambros 1991); g - Trnava-Horné pole (Bielichová 2017); h - Štúrovo (Ambros 1984).

of observed range support the previous observations of larger cattle in Štúrovo and Trnava, but in average the length of cattle tali from Germanic sites is $62.5 \mathrm{~mm}$. For comparison, In Bernhardstahl the average GLl was comparable $-60.8 \mathrm{~mm}$ (range 53.2-72.0; Riedel 1996, 122, tab. 47). Larger tali with the average of $67 \mathrm{~mm}(53.5-80)$ were reported for the mixed cattle population from Tác-Gorsium (data adopted from Benecke 1994, 372, 373, tab. 43). The talus dimensions from Germanic Bruckneudorf speak for two coexisting populations. The one representing smaller type of cattle had its peak of GLl between $60-63.5 \mathrm{~mm}$ and the second, representing larger type, between $68.0-71.5 \mathrm{~mm}$ (Pucher 2016, 280, diagram 24). Considering these results, the bigger tali from Vel'ké Zálužie represent the 'intermediate' middle-sized cattle. Similar to the withers height, more sexually determinable bones and more assemblages need to be analysed to attest our 'preliminary' observations.

For other domesticates, the assemblage provided very limited information (up to ten measurable elements). Few better preserved mandible fragments of pigs suggested their 'small size' typical for the Roman period sites (e.g. Bökönyi 1974; 1984; Fabiš 2003; Riedel 1996). As for the caprines, the horned form of sheep was evidenced. The visual compari- son of partially preserved ulna of an adult sheep $23 / 9$ to the reference material in the laboratory (male of modern 'Valaška' breed) showed that it belonged to a larger and more robust animal, perhaps ram. The other possibility is larger type (breed) of a sheep. It has been argued that Germanic sheep from Nitra-Chrenová was significantly larger than the sheep from the Iron Age settlements in Nitra and fits very well to the variation range of Roman sheep kept in Pannonia (Fabiš 2003). Unfortunately, there are not enough data to study this species in more details. A few data on sheep/goat ulnas can be retrieved from Germanic settlement in Bruckneudorf, indicating that the animals were of similar dimensions as specimens from Velké Zálužie (compare data from Tab. A7 to Bruckneudorf sheep average - SDO 24.4; DPA 28.8; SLC 20.4; Pucher 2016, 351, tab. 50). Dog remains from Vel'ké Zálužie most probably represent small to midsized animal (female?) with narrow and gracile limbs. The visual comparison of horse scapula showed that the size and robustness is similar or slightly larger in comparison to the reference horse individual in the laboratory (stallion recovered at early medieval cemetery in Dubovany-Pápež with the withers height of $133 \mathrm{~cm}$ ). If recorded measurements are compared to other contemporaneous 


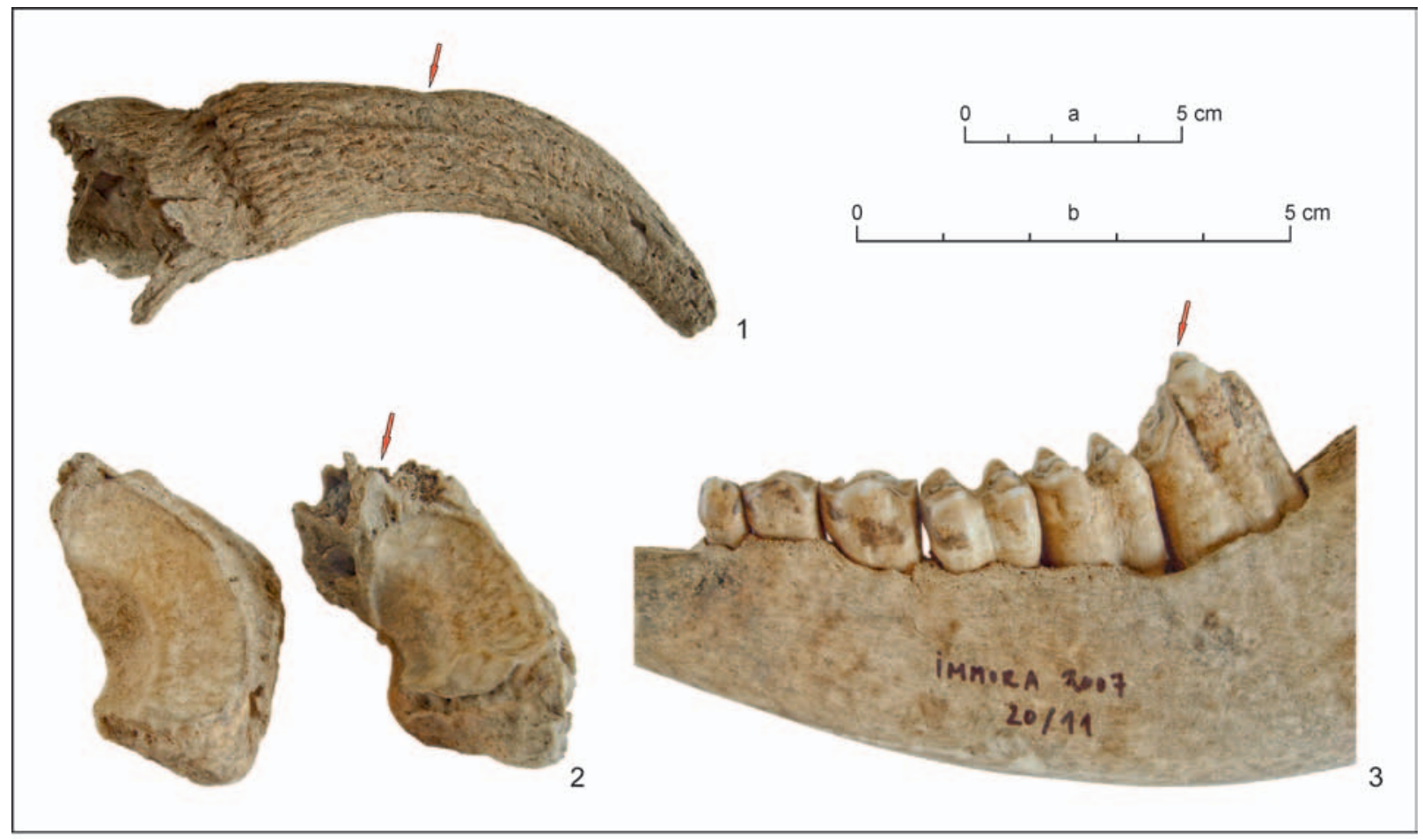

Fig. 21. Vel'ké Zálužie-Ďuriho sad. The palaeopathological finds. 1 - unilaterally flattened horn-core of cattle (specimen 7/1); 2 - exostosis above the articular surface of the third cattle phalanx. Not affected specimen on the left, affected specimen 14/2 on the right; 3 - overgrown third permanent molar in cattle mandible (specimen 20/11). Arrows point to the affected areas.

finds, similar dimensions are seen for instance in the male individual from Nitra-Chrenová (Fabiš 2003, 126, tab. 12f). The horses from Germanic Bruckneudorf, a settlement within the Roman sphere of control, show slightly lower average for the scapula. Compared to specimen from Vel'ké Zálužie (SLC = 66.8; GLP = 94.1; LG = 55.9; BG = 50.4) dimensions of the Bruckneudorf horses were as follows: mean SLC $=60.3 \mathrm{~mm}$ (range 53.5-67.5 mm), mean GLP $=88.1$ (77.5-100), mean LG $=53.9(47-59)$ and mean $B G=46.1(40.5-52.5 \mathrm{~mm}$; adopted from Pucher 2016, 363, tab. 77).

\section{Skeletal pathologies and anomalies}

Two types of pathological conditions have been recorded in the studied assemblage: joint disease and developmental tooth anomalies (Bakerl Brothwell 1980). The first group is represented by an example of distinctive deformities of a cattle phalanx (specimen 14/2). The chronic proliferative processes resulted in the development of exostoses altering the natural shape of the bone (Fig. 21: 2). The changes are visible mainly on the dorsal edge of the articulation, but a single osteophyte occurred also on the tuberculum flexiorum. The comparative study of modern draught cattle in Romania relates such deformations to the age of the individual and the extensive use of animals in lumbering operations (Bartosiewicz et al. 1997). According to the classification proposed by the study, our specimen represents an advanced $4^{\text {th }}$ stage (Bartosiewicz et al. 1997, 56, fig. 39.4). Similar arthropaties are widely found in archaeozoological assemblages and are usually explained by the exploitation of animals for labour (e.g. Ambros et al. 2011; Fabiš 2005). However, as similar changes may occur also spontaneously with age or due to other causes (e.g. localized inflammation), identifying a working animal on the basis of a single case would be difficult (e.g. Bartosiewicz 2013).

Following with bone changes that may be caused by work, the find of a deformed cattle horn-core deserves attention. The specimen $7 / 1$ - presumably a subadult female (see above) is unilaterally compressed in the middle. Looking from above on the skull, this 'flattening' noticeably narrowed the middle of the core's circumference (Fig. 21: 1). Moreover, there is a unilaterally developed, ringshaped depression on the nuchodorsal part of the base circumference. Similar impressions in cattle horn-cores have been attributed to harnessing using horn-yokes (e.g. Bartosiewicz 2013, 133, fig. 109; Peške 
1985, 434, fig. 1). However, changes in our specimen are weakly manifested and were not found in a typical position, so their causes are dubious. Such malformatrion of horns may reflect an inherited anomaly or arrested growth as well.

As far as tooth anomalies are concerned, a cattle mandible (specimen 20/11) showed abnormal attrition of permanent teeth. In the left side of the mandible the third permanent molar is clearly overgrown and projects above the normal occlusal level of the tooth row (Fig. 21:3). This state known as maloclusio, being mostly registered in herbivores. It may have many causes including the congenital absence of the opposing tooth, premature loss of teeth due to trauma or partial destruction (Baker/Brothwell 1980; Bartosiewicz 2013). It may also lead to the chronic irritation and inflammation of the adjacent gum area. Similar finds have been reported from other sites in Slovakia, such as early medieval Bajč (Miklíková 2008, 67, fig. 9.9) or prehistoric Svodín (Ambros et al. 2011, 197, 198, fig. 2.3.1.15, 1.16). In addition to maloclusio, two cases of oligodontia occurred in two of ten presented pig mandibles. The first permanent premolar was bilaterally absent in specimens 10/1 and $12 / 9 .{ }^{16}$ Oligodonty is widespread among pigs and is usually considered a symptom of domestication (Bartosiewicz 2013, 197, 198). The congenital absence of teeth is usually a family linked feature displaying different frequencies among populations (Baker/Brothwell 1980, 137).

\section{CONCLUSIONS}

Excavations at the Late Roman period settlement at Vel'ké Zálužie-Ďuriho sad yielded animal bones $(n=321)$ that represent mixed household waste resulting from butchery, consumption and craft activities. The material was found deposited within the excavated area and the strata of a single hut with sunken floor, three storage pits, two waste pits, four clay extraction pits, and eleven non-specific settlement pits. Complex intra- as well as inter-site evaluation clearly indicated that local economy and subsistence were based on the farming of domestic animals. The main food (meat) providers was cattle and pig. In terms of diet, some wild animals (especially red deer) and caprines represented the second major source of meat, while horse and dogs were probably not consumed. It seems that deer hunting was a common and regular part of daily-life. The most significant results on particular species and the studied aspects are summarized as follows:
- The assemblage showed predominance of domestic animals $(64.2 \%$ of NISP; $82.8 \%$ of MNI; $86 \%$ of WISP) suggesting their importance for local husbandry and economy. So far similar results were obtained at all investigated Roman period settlements from southwestern Slovakia (Tab. 6; 8) or beyond (e.g. Benecke 1994; Bökönyi 1974; Vörös 2002).

- Domestic animals kept at Vel'ké Zálužie were cattle, pig, caprines (only sheep identified), dog and horse. Remains of poultry including chicken, goose or duck that have been sporadically reported from the sites within the studied region (Tab. 7), were not identified at Vel'ké Zálužie. Similarly, cat or donkey, introduced by Romans to the region during the Early Roman period, did not occurr at the studied site.

- Regarding meat consumption, the WISP clearly shows that cattle was the most important provider of meat (61.5\%). Additional sources of meat were represented by pigs (14.4\%) that clearly outweighed caprines $(7.6 \%)$ and cervids ( $6.3 \%)$. The minimal number of individuals (MNI) further indicated, that pigs (31\%) were most frequently slaughtered for meat, as a consequence of their higher reproduction rate, availability and exclusive meat exploitation (cattle and caprines were also kept for secondary products, see below). Cattle (24.1\%), caprines (17.2\%) and deer $(17.2 \%)$ were slaughtered less common. In accordance with the increase of pork consumption observed at sites in the Bratislava region (Šefćáková 2011) the studied assemblage points to the importance of pork within the meat diet. The 'cattle and pork' dietary pattern has been attested at the majority of Germanic sites from southwestern Slovakia or Middle Danube region (Fig. 11; Tab. 7). However, regarding to ratio of pig to caprines, results vary from site to site (Fig. 12). At some sites caprine bones occurred in equal number with (Vel'ké Zálužie, NitraChrenová, Štúrovo) or even outnumbered those of pigs (Most pri Bratislave, Vel'ký Meder). The reasons may have cultural or environmental origins. A clear 'caprine or caprine/pork dietary pattern' was observed at Roman provincial sites located in the territory of Slovakia (Fig. 11; Tab. 7).

- Large game from Vel'ké Zálužie included two species - red deer and roe deer. Together their bones made up notable proportion of finds $(10 \%$ of NISP; $17.2 \%$ of MNI; $6.2 \%$ of WISP) which indicated the importance of hunting in provision of food (meat). The age of a partial skeleton

\footnotetext{
${ }^{16}$ The X-ray for distinguishing real oligodontia from the state of tooth retention was not yet applied for the find.
} 
of a red deer fawn found in pit 54, if killed during the hunt (see below), helps to providing the information on the season of the 'event' - late summer/early autumn (August-September). Records of wild animals hunted during the Roman period in southwestern Slovakia showed that red deer as the most important prey of hunters. Other wild mammals such wild boar, aurochs, hare, roe deer, wolf, fox, and beaver were hunted by the local Germanic populations. Wild birds and fish were, however, identified only rarely (Tab. 7). Interestingly, the studied site showed the largest NISP of wild mammals recorded yet (Tab. 8).

- The study of body parts and skeletal element representation indicate that cattle, pig, caprines (at least sheep) and red deer have been kept alive or transported to the site as complete carcasses. The presence of a nearly intact, partially preserved red deer fawn skeleton in one of the pits also points to the possibility of keeping wild animal alive at the site (Fig. 15). This finds may represent naturally died animal, but also remnants of successful hunt and a delicate 'meat dish' for more people. The possibility of being a part of some 'ritual' (as a food?) cannot be verified due to missing recovery documentation. As for the representation of meaty and meatless skeletal elements in particular species it has been shown that while in cattle low and medium 'quality' elements prevail, pig was mostly represented by high and medium quality body parts. Bone refuse from the house had the largest proportion of elements associated with high quality meat, while the highest percentage of primary butchery waste was deposited in two waste pits (Fig. 13). The weight difference method showed similarities in skeletal element distribution in cattle from two Late Roman settlements at Vel'ké Zálužie and Nitra-Chrenová (Fig. 14; Tab. A3).

- The absence of information on the type of this site (seasonal/year round?) and socio-economic status of inhabitants as well as limited demographic data on animals prevent the assessment of slaughter and stock breeding practices in the studied village. The regional data in this respect point to the controlled kill-off of livestock in line with traditional peasant practices where females are kept in higher numbers. Some indices revealed by the analysis of age and sex suggest that Germanic people at Vel'ké Zálužie followed the same strategy. In cattle, a single horn-core find and a few metapodials pointed to the expected predominance of females (cows) in the cull (Tab. 9) and vice-versa males in pigs.
Although limited, ageing data help deducing primarily meat exploitation in cattle with most slaughter taking place before reaching adulthood (mostly in 2-6 months and 2-4 years; Tab. A4-6). This result is slightly different from what was observed in the contemporaneous settlement at Nitra-Chrenová, where a clear predominance of adults and mainly dairy and draught purpose cattle could be presumed (Fig. 19). The absence of clear examples of castrated cattle (oxen), present at Nitra-Chrenová, provides another indicator of different modes of livestock exploitation at these two sites. In pigs, slaughter during the first or second year was observed. In caprines all kinds of age categories except the 1-2 years age category, that is the most ideal for the slaughter, were recorded. This may indicate keeping sheep (and goats) primarily for secondary products such as milk and wool/hair or exporting mutton outside the village (same also observed at Nitra-Chrenová site - Fabiš 2003).

- At Vel'ké Zálužie, measurable skeletal elements indicated that local cattle most possibly belonged to a small-bodied and short-horned (brachyceros) type. The withers height, estimated according to the metapodials and Matolcsi's coefficients, was between 109.3-112.7 $\mathrm{cm}$ in females (average $110.9 \mathrm{~cm}, \mathrm{n}=3$ ) and $115.8-116 \mathrm{~cm}$ in males (average $115.9 \mathrm{~cm}, \mathrm{n}=2$ ). The average for the site was $113.7 \mathrm{~cm}$ that correspondents to $350 \mathrm{~kg}$ of the live weight (333 kg in females; $367 \mathrm{~kg}$ in males). Compared to cattle sizes calculated on the basis of finds from Germanic sites from southwestern Slovakia $(117 \mathrm{~cm} ; 382 \mathrm{~kg})$ these cattle were slightly smaller, which may be seen as a logical consequence of having more females represented in the sample (Tab. 10). Additional investigation of talus bone of cattle (Tab. 11), however, revealed that some cattle from Vel'ké Zálužie reach the size parameters of Germanic middle-sized cattle from Bruckneudorf (Austria), where the coexistence of several types, perhaps autochthonous and Italic forms, was reported (Pucher 2016).

- The traces of slicing, chopping and breaking of bones, attesting the human manipulation of animal carcasses, were frequently recorded in cattle, caprines, pigs and deer (Tab. 3). Their absence in dog and horse bones points to the different modes of exploitation and at best sporadic contribution to the diet. Clear examples of initial stages (e.g. killing/removal of the head), the secondary and tertiary butchery (e.g. dismembering of joints, reduction of bigger parts to smaller pot-sized portions) and marrow extraction have been identified 
(Fig. 6). Although a general pattern cannot be clearly recognized in the small assemblage, we observed more intense butchery with metal tools at Vel'ké Zálužie than in other Germanic assemblages from southwestern Slovakia (e.g. in Trnava-Horné pole - Bielichová 2017). Even if no metal artefacts were found during excavation, the use of large-bladed implements (axe/ cleaver) was attested (Fig. 7).

- The lack of burning (recorded on a single specimen) support the idea of peaceful abandonment of the settlement with no 'fire' events. Most probably, quantities of food refuse were intentionally discarded into one of the used waste pits (and not thrown into the fire). Absence of burning can point to local food preparation, perhaps boiling, baking or roasting the meat without bones. Restricted access to the garbage (at least at this part of settlement) is also shown by the absence of rodent gnawing. On the other hand, gnawing of bones by dogs occurred across the whole area (Fig. 8). Human and dogs contributed significantly to the overall fragmentation of skeletal elements (Fig. 10; Tab. 5).

- A small collection of bone artefacts included two clearly and three tentatively worked items (Fig. 9; Tab. 4). The recorded modifications offered evidence of the exploitation of domestic raw materials - cattle and deer skeletal elements (talus and costae fragments). The implements can be connected with crafts, most probably textile and pottery production. Four (out of five) of the items originated from two pits - no. 9 and no. 15 . An intentionally modified knuckle bone (talus) of cattle could be interpreted as a game piece, although its connection to pottery craft cannot be ruled out (Fig. 9: 4, 5).

- Archaeozoological data from Roman period sites of southwestern Slovakia, shortly reviewed in this paper, provide limited but important evi- dence of cultural contacts between Barbarians with the Roman-provincial world and the 'romanization' of the region. In this respect, most convincing are the finds of newly introduced domestic animals such as donkey, cat or pigeon on Germanic settlements. The scarcity of butchery, age, and sex or osteometric data still hampers information on continuity or change in subsistence and husbandry regimes of individual settlements. The complexity of Roman period socio-economic changes, presumably involving animal keeping, may be further elucidated only through more elaborated analyses of reasonably large bone assemblages with clear chronological context (cf. Albarella/Johnstone/Vickers 2008). In Slovakia it is inevitable to unify and standardize the methodology of archaeozoological research and publish full raw data in order to building up a sufficiently large study collection of Roman period zoological information (see Atici et al. 2013). ${ }^{17}$

\section{APPENDIX}

The supplementary material, providing additional archaeozoological data on the studied assemblage, is attached to this paper in the form of tables. It includes information on taxonomic identification within settlement features (Tab. A1), the representation of skeletal elements in identified animal taxa (Tab. A2), the representation of skeletal elements in cattle from Vel'ké Zálužie and Nitra-Chrenová on the basis of the weight difference method (Tab. A3), the distribution of age categories within the identified taxa (Tab. A4), the distribution of dental age categories in cattle, caprines and pig (Tab. A5), the epiphyseal ageing in cattle, caprines, pig and deer (Tab. A6) and full osteometric data (Tab. A7).

\footnotetext{
${ }^{17}$ Acknowledgements: The author is grateful to all colleagues who contributed to the final state of the paper. Mário Bielich and Zuzana Poláková provided archaezoological material and details on recovery methods as well as data from pottery analysis. Marián Fabiš, Alena Šef̌ćḱková and Cyril Ambros provided unique unpublished data from their analysis of the Roman period animal bone material. Vladimír Varsik commented on dating of sites and provided information on unpublished metal finds from Cífer-Pác. Valuable comments on earlier drafts and English revision of this paper were provided by Mária Hajnalová and László Bartosiewicz. Peter Červeň helped to assemble the map and figures.
} 


\begin{tabular}{|c|c|c|c|c|c|c|c|c|c|c|c|c|c|c|c|c|c|c|}
\hline \multicolumn{2}{|c|}{$\begin{array}{l}\sum_{z}^{*} \\
\sum_{0} \\
\frac{1}{Z}\end{array}$} & $\stackrel{\substack{* \\
\stackrel{0}{\infty}}}{\stackrel{2}{0}}$ & $\begin{array}{l}\text { 产 } \\
\stackrel{9}{9}\end{array}$ & $\overbrace{\text { to }}^{*}$ & 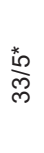 & $\stackrel{*}{N}$ & $\overbrace{}^{*}$ & $\stackrel{\stackrel{m}{j}^{*}}{\stackrel{*}{*}}$ & $\stackrel{*}{\Sigma}$ & $\stackrel{*}{\stackrel{*}{\prime}}$ & $\frac{1}{\gamma}$ & $\frac{1}{N}$ & $\stackrel{1}{r}$ & $\frac{1}{\frac{1}{0}}$ & $\frac{1}{N}$ & $\frac{1}{\grave{N}}$ & $\stackrel{\frac{1}{\infty 0}}{\infty}$ & 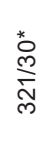 \\
\hline \multirow{22}{*}{ 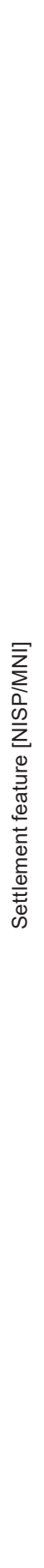 } & $\stackrel{\infty}{\circ}$ & 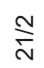 & 1 & 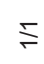 & 1 & $\Sigma$ & 1 & $\xi$ & 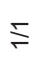 & $r$ & 1 & $N$ & 1 & - & 1 & 1 & m & 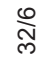 \\
\hline & Lే & 1 & I & 1 & 1 & 1 & 1 & స్స & 1 & 1 & 1 & 1 & 1 & 1 & 1 & I & 1 & $\overline{\mathbf{N}}$ \\
\hline & i & $\Sigma$ & 1 & 1 & 1 & 1 & 1 & 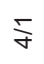 & 1 & 1 & 1 & 1 & 1 & 1 & 1 & 1 & 1 & $\stackrel{\cong}{6}$ \\
\hline & $\hat{f}$ & 1 & $\stackrel{N}{N}$ & $\risingdotseq$ & 㐌 & 1 & 1 & 1 & 1 & 1 & 1 & 1 & 1 & 1 & 1 & N & $r$ & $\stackrel{t}{\sigma}$ \\
\hline & $\stackrel{m}{m}$ & $\bar{N}$ & 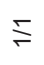 & 1 & is & 1 & 1 & 1 & 1 & 1 & 1 & 1 & 1 & 1 & 1 & $\sigma$ & 1 & $\stackrel{m}{\sim}$ \\
\hline & ల) & 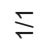 & I & 1 & 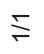 & 1 & 1 & $\sqrt{\mathrm{N}}$ & 1 & 1 & $\sim$ & 1 & 1 & 1 & 1 & $r$ & $N$ & $\frac{m}{\sigma}$ \\
\hline & $\stackrel{\sim}{N}$ & 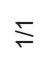 & $\Sigma$ & I & 1 & 1 & 1 & 1 & 1 & 1 & - & 1 & 1 & 1 & - & I & 1 & $\stackrel{N}{f}$ \\
\hline & $\stackrel{\sim}{N}$ & $\overline{\mathrm{N}}$ & 1 & 1 & 1 & 1 & 1 & 1 & 1 & 1 & 1 & 1 & 1 & 1 & 1 & 1 & 1 & $\bar{N}$ \\
\hline & $\approx$ & 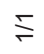 & $\stackrel{\Sigma}{N}$ & 1 & 1 & 1 & 1 & 1 & 1 & I & 1 & 1 & 1 & 1 & 1 & 1 & 1 & $\frac{N}{m}$ \\
\hline & $\stackrel{9}{\leftarrow}$ & $\mathcal{\gamma}$ & $\Sigma$ & $\Sigma$ & 1 & 1 & 1 & 1 & 1 & 1 & 1 & 1 & 1 & $r$ & $N$ & 1 & $N$ & 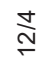 \\
\hline & $\stackrel{\infty}{\leftarrow}$ & $\bar{N}$ & 1 & 1 & 1 & 1 & 1 & 1 & 1 & 1 & 1 & 1 & 1 & 1 & 1 & 1 & 1 & $\bar{\sim}$ \\
\hline & $\stackrel{2}{\underline{2}}$ & $\underset{\Sigma}{\Sigma}$ & ז & 1 & $\frac{\Gamma}{m}$ & 1 & 1 & $\xi$ & 1 & I & 1 & 1 & 1 & 1 & $\infty$ & 1 & - & $\underset{⿱}{\mathbb{N}}$ \\
\hline & $\stackrel{J}{\sim}$ & 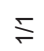 & I & 1 & 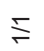 & 1 & 1 & 1 & 1 & I & - & 1 & 1 & 1 & 1 & $\sim$ & 1 & $\frac{\sqrt{5}}{\mathrm{~N}}$ \\
\hline & $F$ & 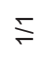 & $\bar{N}$ & 1 & 1 & 1 & I & 1 & 1 & 1 & 1 & 1 & 1 & 1 & $r$ & - & 1 & $\frac{m}{\omega n}$ \\
\hline & 음 & $\stackrel{m}{\circ}$ & $\stackrel{\mathcal{F}}{\mathcal{F}}$ & $\Sigma$ & 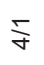 & 1 & 1 & 1 & 1 & 1 & 1 & 1 & 1 & $m$ & $m$ & - & $m$ & సे \\
\hline & $\sigma$ & $\frac{m}{\infty}$ & $\frac{m}{0}$ & 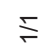 & N & 1 & 1 & 1 & 1 & I & 1 & 1 & 1 & 1 & - & - & 1 & 흗 \\
\hline & $\infty$ & $\frac{N}{m}$ & $\frac{\Gamma}{m}$ & $\Sigma$ & $r$ & 5 & 1 & 1 & 1 & 1 & 1 & 1 & 1 & 1 & 1 & $r$ & 1 & $\stackrel{\llcorner}{\partial}$ \\
\hline & $\leqslant$ & 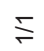 & 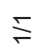 & I & 1 & 1 & 1 & 1 & 1 & I & 1 & 1 & I & 1 & I & I & 1 & $\stackrel{\sim}{N}$ \\
\hline & r & 1 & $\risingdotseq$ & 1 & $\Xi$ & 1 & 1 & 1 & 1 & 1 & 1 & 1 & 1 & 1 & 1 & 1 & 1 & 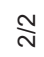 \\
\hline & 0 & $\stackrel{m}{\mathbf{N}}$ & $\frac{m}{b}$ & $\Sigma$ & $\frac{5}{\sigma}$ & 1 & 1 & 1 & 1 & 1 & I & 1 & - & 1 & $m$ & $\nabla$ & 1 & $\stackrel{\infty}{b}$ \\
\hline & مص & $\stackrel{m}{\underline{c}}$ & $\stackrel{m}{\sigma}$ & $\underset{\sim}{\Sigma}$ & $\underset{m}{\Sigma}$ & 1 & 1 & $\Sigma$ & I & 1 & I & 1 & 1 & ما & $m$ & $N$ & 0 & 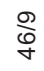 \\
\hline & $\sim$ & 1 & $\frac{\Gamma}{m}$ & 1 & 1 & 1 & $\delta$ & 1 & 1 & 1 & I & 1 & 1 & 1 & 1 & - & 1 & $\underset{\infty}{\stackrel{N}{N}}$ \\
\hline \multicolumn{2}{|c|}{ 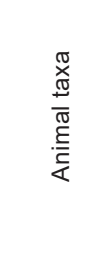 } & 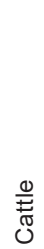 & $\frac{1}{2}$ & $\frac{\stackrel{0}{0}}{\frac{\Phi}{\omega}}$ & 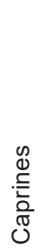 & 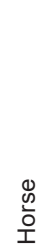 & $\stackrel{\circ}{\circ}$ & $\begin{array}{l}\bar{\Phi} \\
\mathbb{D} \\
\overline{0} \\
\mathbb{Q}\end{array}$ & 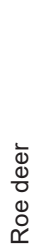 & 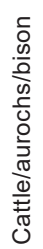 & 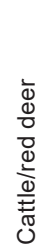 & 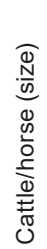 & 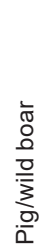 & 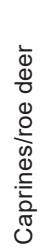 & 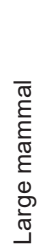 & 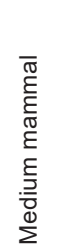 & $\begin{array}{l}\overline{\widetilde{\varpi}} \\
\bar{E} \\
\sum\end{array}$ & $\begin{array}{l}\bar{\sigma} \\
\stackrel{\sigma}{\circ}\end{array}$ \\
\hline
\end{tabular}


Tab. A2. Vel'ké Zálužie-Ďuriho sad. The skeletal element representation according to taxa. Quantified after NISP.

\begin{tabular}{|c|c|c|c|c|c|c|c|c|c|c|c|c|c|c|c|c|c|}
\hline \multirow[b]{2}{*}{ Skeletal element } & \multicolumn{16}{|c|}{ Animal taxa } & \multirow[b]{2}{*}{$\frac{0}{2}$} \\
\hline & 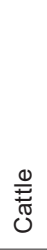 & $\frac{\text { 믐 }}{\alpha}$ & $\begin{array}{l}\frac{8}{\Phi} \\
\frac{\Phi}{\omega}\end{array}$ & 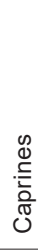 & $\begin{array}{l}\stackrel{0}{\infty} \\
\stackrel{0}{0} \\
\text { 오 }\end{array}$ & : & 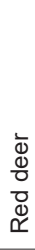 & 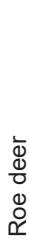 & 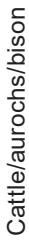 & 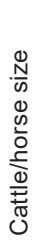 & 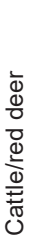 & 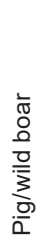 & 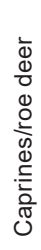 & 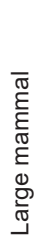 & 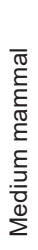 & 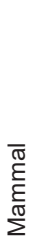 & \\
\hline Processus cornualis & 1 & - & 1 & - & - & - & 1 & - & - & - & - & - & - & - & - & - & 3 \\
\hline Neurocranium & - & - & - & - & - & - & 1 & - & - & - & - & - & - & - & 1 & - & 2 \\
\hline Cranial element & 1 & - & - & - & - & - & 1 & - & - & - & - & - & - & - & - & - & 2 \\
\hline Occipitale & - & 2 & - & - & - & - & - & - & - & - & - & - & - & - & - & - & 2 \\
\hline Frontale & 2 & - & - & - & - & - & - & - & - & - & - & - & - & - & - & - & 2 \\
\hline Temporale & 2 & 2 & - & - & - & - & - & - & - & - & - & - & - & - & - & - & 4 \\
\hline Zygomaticum & 3 & - & - & - & - & - & - & - & - & - & - & - & - & - & - & - & 3 \\
\hline Nasale & - & - & - & - & - & - & - & - & - & - & - & - & - & - & 2 & - & 2 \\
\hline Palatum & 2 & 1 & - & - & - & - & - & - & - & - & - & - & - & - & - & - & 3 \\
\hline Parietale & - & 1 & - & - & - & - & - & - & - & - & - & - & - & - & - & - & 1 \\
\hline Praemaxilla & - & - & - & 1 & - & - & - & - & - & - & - & - & - & - & - & - & 1 \\
\hline Incisivus & - & 1 & - & - & - & - & - & - & - & - & - & - & - & - & - & - & 1 \\
\hline Maxilla & 1 & - & - & - & - & - & - & - & - & - & - & - & - & - & - & - & 1 \\
\hline Maxilla + dens & 1 & 3 & - & - & - & - & - & - & - & - & - & - & - & - & - & - & 4 \\
\hline Mandibula & 7 & 7 & - & 1 & - & - & - & - & - & - & - & - & - & - & - & - & 15 \\
\hline Mandibula + dens & 5 & 10 & 3 & 4 & - & - & 1 & - & - & - & - & - & - & - & - & - & 23 \\
\hline Canine inf. & - & 2 & - & - & - & - & - & - & - & - & - & 1 & - & - & - & - & 3 \\
\hline Caninus decid. & - & 1 & - & - & - & - & - & - & - & - & - & - & - & - & - & - & 1 \\
\hline Caninus sup. & - & 2 & - & - & - & - & - & - & - & - & - & - & - & - & - & - & 2 \\
\hline Incisivus 2 inf. & - & 1 & - & - & - & - & - & - & - & - & - & - & - & - & - & - & 1 \\
\hline Premolar sup. & 1 & - & - & - & - & - & - & - & - & - & - & - & - & - & - & - & 1 \\
\hline Molar 3 inf. & 1 & - & - & - & - & - & - & - & - & - & - & - & - & - & - & - & 1 \\
\hline Molar 3 sup. & - & - & - & 1 & - & - & - & - & - & - & - & - & - & - & - & - & 1 \\
\hline Molar sup. & 2 & - & - & - & - & - & - & - & - & - & - & - & - & - & - & - & 2 \\
\hline Atlas & - & 1 & 1 & - & - & - & - & - & - & - & - & - & - & - & - & - & 2 \\
\hline Axis & - & - & - & - & - & - & 1 & - & - & - & - & - & - & - & - & - & 1 \\
\hline Costa & 15 & - & - & 5 & - & - & 4 & - & - & 2 & 1 & - & 8 & 5 & 3 & 7 & 50 \\
\hline Hyoideum & 1 & - & - & - & - & - & 1 & - & - & - & - & - & - & - & - & - & 2 \\
\hline Osificated cartilago & - & - & - & - & - & - & - & - & - & - & - & - & - & 1 & - & - & 1 \\
\hline Vertebra & - & - & - & - & - & - & - & - & - & - & - & - & - & - & 1 & 1 & 2 \\
\hline Vertebra cervicalis & 1 & - & - & - & - & - & 1 & - & 1 & - & - & - & - & - & - & - & 3 \\
\hline Vertebra lumbalis & 2 & - & - & - & - & 2 & - & - & - & - & - & - & - & - & - & - & 4 \\
\hline Vertebra thoracica & - & - & - & - & - & - & - & - & - & - & - & - & - & 1 & - & - & 1 \\
\hline Humerus & 5 & 2 & 1 & - & - & - & 2 & - & - & - & - & - & - & - & 1 & - & 11 \\
\hline Radius & 6 & - & 1 & 5 & - & 1 & 2 & - & - & - & - & - & 1 & - & - & - & 16 \\
\hline Scapula & 5 & - & - & - & 1 & - & 1 & - & - & - & - & - & - & - & - & 1 & 8 \\
\hline Ulna & 1 & 5 & 3 & 2 & - & - & 1 & - & - & - & - & - & - & - & - & - & 12 \\
\hline Pelvis & - & - & - & 1 & - & - & - & - & - & - & - & - & - & 1 & - & - & 2 \\
\hline Pelvis + acetabulum & - & 1 & - & - & - & - & - & - & - & - & - & - & - & - & - & - & 1 \\
\hline Ilium + acetabulum & - & - & - & - & - & - & 1 & - & - & - & - & - & - & - & - & - & 1 \\
\hline Ischium & 2 & - & - & - & - & - & - & - & - & - & - & - & - & - & - & - & 2 \\
\hline
\end{tabular}


Tab. A2. Continuation.

\begin{tabular}{|c|c|c|c|c|c|c|c|c|c|c|c|c|c|c|c|c|c|}
\hline \multirow[b]{2}{*}{ Skeletal element } & \multicolumn{16}{|c|}{ Animal taxa } & \\
\hline & 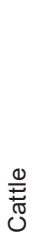 & . & $\begin{array}{l}\frac{\otimes}{\otimes} \\
\frac{\Phi}{\omega}\end{array}$ & : & $\begin{array}{l}\$ \\
\text { 心 } \\
\text { 호 }\end{array}$ & : & 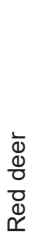 & 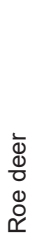 & 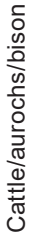 & 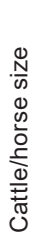 & 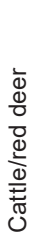 & $\begin{array}{l}\frac{1}{\pi} \\
\text { o } \\
\frac{0}{0} \\
\frac{0}{3} \\
\frac{0}{2}\end{array}$ & 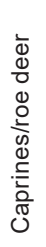 & 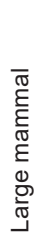 & 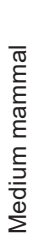 & $\begin{array}{l}\overline{\widetilde{\sigma}} \\
\sum_{\tilde{E}} \\
\sum^{\frac{\pi}{\Sigma}}\end{array}$ & $\frac{n}{\frac{0}{z}}$ \\
\hline Ischium + acetabulum & 1 & - & - & 1 & - & - & 1 & - & - & - & - & - & - & - & - & - & 3 \\
\hline Femur & 3 & 1 & - & 3 & - & - & 1 & - & - & - & - & - & - & - & 1 & 1 & 10 \\
\hline Tibia & 5 & 3 & - & 6 & - & - & 2 & - & - & - & 2 & - & 1 & - & 1 & - & 20 \\
\hline Fibula & - & 1 & - & - & - & - & - & - & - & - & - & - & - & - & - & - & 1 \\
\hline Metacarpus 3/4 & 11 & - & - & 1 & - & - & 1 & - & - & - & - & - & - & - & - & - & 13 \\
\hline Metacarpus 5 & - & - & - & - & - & 1 & - & - & - & - & - & - & - & - & - & - & 1 \\
\hline Phalanx I ant. & 1 & - & - & - & - & - & - & - & - & - & - & - & - & - & - & - & 1 \\
\hline Calcaneus & 2 & - & - & - & - & - & 1 & - & - & - & 1 & - & - & - & - & - & 4 \\
\hline Talus & 4 & 1 & - & - & - & - & 1 & - & - & - & - & - & - & - & - & - & 6 \\
\hline Metatarsus 3/4 & 7 & - & - & 2 & - & - & 3 & 1 & - & - & - & - & - & - & - & - & 13 \\
\hline Centrotarsale & - & - & - & - & - & - & 1 & - & - & - & - & - & - & - & - & - & 1 \\
\hline Phalanx I post. & 2 & - & - & - & - & - & - & - & - & - & - & - & - & - & - & - & 2 \\
\hline Metapodium & 1 & - & - & - & - & - & - & - & - & - & - & - & - & - & - & - & 1 \\
\hline Metapodium lat. & - & 1 & - & - & - & - & - & - & - & - & - & - & - & - & - & - & 1 \\
\hline Phalanx I & - & - & - & - & - & - & 1 & - & - & - & - & - & - & - & - & - & 1 \\
\hline Phalanx II & 1 & - & - & - & - & - & - & - & - & - & - & - & - & - & - & - & 1 \\
\hline Phalanx III & 3 & - & - & - & 1 & - & - & - & - & - & - & - & - & - & - & - & 4 \\
\hline Unidentified & - & - & - & - & - & - & 1 & - & - & - & - & - & - & 14 & 15 & 8 & 38 \\
\hline
\end{tabular}

Tab. A3. Vel'ké Zálužie-Ďuriho sad. The cattle skeletal element representation at Vel'ké Zálužie and Nitra-Chrenová sites. WISP diff. = difference from the reference skeleton values (after Kunst 2002). Quantified after WISP.

\begin{tabular}{|l|c|c|c|c|c|}
\hline \multicolumn{1}{|c|}{ Skeletal element } & $\begin{array}{c}\text { Weight of element } \\
\text { [\%] in the reference } \\
\text { individual }\end{array}$ & $\begin{array}{c}\text { Vel'ké Zálužie } \\
\text { [\% of WISP] }\end{array}$ & $\begin{array}{c}\text { Nitra-Chrenová } \\
\text { [\% of WISP] }\end{array}$ & $\begin{array}{c}\text { Vel'ké Zálužie } \\
\text { [WISP diff.] }\end{array}$ & $\begin{array}{c}\text { Nitra-Chrenová } \\
\text { [WISP diff.] }\end{array}$ \\
\hline Cranium & 8.41 & 7.26 & 10.01 & -1.15 & 1.60 \\
Mandibula & 4.81 & 18.91 & 13.70 & 14.10 & 8.89 \\
Vertebrae & 18.79 & 2.61 & 5.97 & -16.18 & -12.82 \\
Costae & 13.86 & 5.20 & 7.43 & -8.66 & -6.43 \\
Scapula & 4.74 & 2.81 & 4.98 & -1.93 & 0.24 \\
Humerus & 6.17 & 5.95 & 3.69 & -0.22 & -2.48 \\
Radius + ulna & 5.51 & 7.74 & 12.17 & 2.23 & 6.66 \\
Metacarpus & 2.04 & 16.51 & 5.58 & 14.47 & 3.54 \\
Pelvis & 8.26 & 1.53 & 7.22 & -6.73 & -1.04 \\
Femur & 9.9 & 3.04 & 4.34 & -6.86 & -5.56 \\
Tibia & 6.69 & 5.41 & 12.89 & -1.28 & 6.20 \\
Basipodium & 4.64 & 6.86 & 3.39 & 2.22 & -1.25 \\
Metatarsus & 2.83 & 13.86 & 4.98 & 11.03 & -1.05 \\
Phalanges & 3.36 & 2.31 & 3.64 & 2.15 \\
\hline
\end{tabular}


Tab. A4. Vel'ké Zálužie-Ďuriho sad. The relative ageing. Quantified after NISP.

\begin{tabular}{|c|c|c|c|c|c|c|c|c|c|c|c|c|c|c|c|c|c|}
\hline \multirow[b]{2}{*}{ Age category } & \multicolumn{16}{|c|}{ Animal taxa } & \\
\hline & 苐 & $\frac{0}{2}$ & $\begin{array}{l}\frac{\otimes}{\otimes} \\
\frac{\mathbb{\sigma}}{\omega}\end{array}$ & 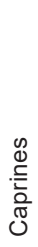 & 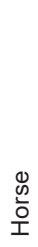 & : & $\begin{array}{l}\bar{\Phi} \\
\Phi \\
0 \\
0 \\
\square \\
\square\end{array}$ & 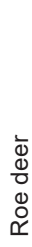 & 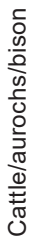 & 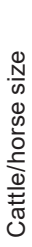 & 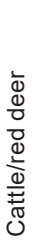 & 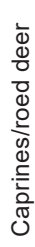 & 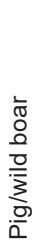 & 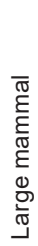 & 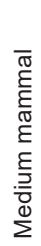 & $\begin{array}{l}\overline{\widetilde{\sigma}} \\
\stackrel{\xi}{\Sigma} \\
\sum^{\mathbb{N}}\end{array}$ & $\frac{0}{\frac{0}{z}}$ \\
\hline Neonatal & 2 & - & - & - & - & - & - & - & - & - & - & - & - & - & - & - & 2 \\
\hline Neonatal/juvenile & 1 & - & - & - & - & - & - & - & - & - & - & - & - & - & - & - & 1 \\
\hline Very juvenile & - & 1 & 1 & 1 & - & - & 22 & - & - & - & - & - & - & - & 1 & - & 26 \\
\hline Juvenile? & - & 1 & - & - & - & - & - & - & - & - & 1 & - & - & - & - & - & 2 \\
\hline Juvenile & 5 & 8 & 1 & - & - & - & - & - & - & - & - & - & - & - & 1 & - & 15 \\
\hline Juvenile/subadult & 12 & 8 & - & 1 & 1 & - & - & - & - & - & - & - & - & 1 & 1 & - & 24 \\
\hline Subadult & 1 & 2 & 1 & - & - & - & 5 & - & - & - & - & - & - & - & - & - & 9 \\
\hline Subadult? & 1 & - & - & - & - & - & - & - & - & - & - & - & - & - & - & - & 1 \\
\hline Subadult/adult & 35 & 14 & 3 & 9 & - & 2 & 1 & 1 & 1 & 1 & 1 & 3 & - & 11 & 3 & 2 & 87 \\
\hline Adult & 28 & 9 & 2 & 9 & 1 & - & 3 & - & - & - & 1 & - & 1 & - & - & - & 54 \\
\hline Adult? & 7 & - & - & 5 & - & - & - & - & - & - & - & - & - & 2 & - & - & 14 \\
\hline Adult/mature & 2 & 1 & 2 & - & - & - & - & - & - & - & - & - & - & - & - & - & 5 \\
\hline Undetermined & 14 & 5 & - & 8 & - & 2 & - & - & - & 1 & 1 & 7 & - & 8 & 19 & 16 & 81 \\
\hline
\end{tabular}

Tab. A5. Vel'ké Zálužie-Ďuriho sad. The dental ageing data in main economic species. Categories A-L according to L. Peške (1994). Quantified after NISP.

\begin{tabular}{|c|c|c|c|}
\hline Dental age category & Cattle & Pig & Caprines \\
\hline A & 2 & - & - \\
B & 1 & - & - \\
C & - & - & 2 \\
D & - & 2 & - \\
E & 1 & 1 & 2 \\
F & - & - & 1 \\
G & - & - & - \\
H & - & 1 & - \\
I & - & 1 & - \\
J & - & - & - \\
K & - & - & - \\
L & - & - & - \\
\hline Total & 4 & 5 & 5 \\
\hline
\end{tabular}

Tab. A6. Vel'ké Zálužie-Ďuriho sad. The epiphyseal fusing data. F - Fused; O - open. Quantified after NISP.

\begin{tabular}{|c|c|c|c|c|c|c|c|c|}
\hline \multirow{3}{*}{ Skeletal element } & \multicolumn{8}{|c|}{ State of epiphyseal fusion } \\
\hline & \multicolumn{2}{|c|}{ Cattle } & \multicolumn{2}{|c|}{ Pig } & \multicolumn{2}{|c|}{ Caprines } & \multicolumn{2}{|c|}{ Deer } \\
\hline & $\mathrm{F}$ & $\mathrm{O}$ & $\mathrm{F}$ & $\mathrm{O}$ & $\mathrm{F}$ & $\mathrm{O}$ & $\mathrm{F}$ & $\mathrm{O}$ \\
\hline Acetabulum & 1 & - & 1 & - & 2 & - & - & 1 \\
\hline Humerus distal & 1 & - & - & - & 1 & - & - & 2 \\
\hline Radius proximal & 1 & - & - & - & - & - & - & 2 \\
\hline Phalanx 1, proximal & 3 & - & - & - & - & - & - & 1 \\
\hline Phalanx 2, proximal & 1 & - & - & - & - & - & - & - \\
\hline Early fusing & 7 & - & 1 & - & 3 & - & - & 6 \\
\hline Calcaneus proximal & - & - & - & - & - & - & - & 1 \\
\hline Metacarpus distal & 4 & 1 & - & - & - & - & - & - \\
\hline Metatarsus distal & 3 & - & - & - & - & - & - & - \\
\hline Tibia distal & - & - & 1 & - & - & - & - & 2 \\
\hline Middle fusing & 7 & 1 & 1 & - & - & - & - & 3 \\
\hline Tibia proximal & - & - & - & 2 & - & - & - & - \\
\hline Radius distal & 1 & 1 & - & - & 1 & - & - & 1 \\
\hline Ulna proximal & - & - & - & - & - & 1 & - & - \\
\hline Femur proximal & - & 1 & - & - & - & - & - & - \\
\hline Vertebral centrum & 2 & 1 & - & - & - & - & - & 1 \\
\hline Late fusing & 3 & 3 & - & 2 & 1 & 1 & - & 2 \\
\hline
\end{tabular}


Tab. A7. Vel'ké Zálužie-Ďuriho sad. The osteometric data. All measurements in mm. Abbreviations and numbers according to A. von den Driesch (1976). M - Measurement; $\mathrm{s}$ - left; $\mathrm{d}$ - right; $\mathrm{n}$ - not sided; $\mathrm{f}$ - female; $\mathrm{m}$ - male.

\begin{tabular}{|c|c|c|c|c|}
\hline Specimen & Skeletal element & Side & Measurements after A. von den Driesch (1976) & Sex \\
\hline \multicolumn{5}{|c|}{ Cattle (Bos taurus) } \\
\hline $7 / 1$ & processus cornualis & s & $M 44=113.4 ; M 45=43.3 ; M 46=33.7 ; M 47=114.5$ & f? \\
\hline $17 / 14$ & mandibula & $\mathrm{d}$ & $M 11=12.0$ & - \\
\hline $20 / 10$ & mandibula & d & $\begin{array}{l}M 7=127.7 ; M 8=77.4 ; M 10(L)=33.1 ; M 10(B)=14.7 ; M 11=15.1 ; M 15 a=65.2 ; M 15 b=45.9 \\
M 15 c=33.5\end{array}$ & - \\
\hline $3 / 2$ & scapula & $\mathrm{s}$ & GLP $=63.7 ; \mathrm{LG}=52.1 ; \mathrm{BG}=43.6$ & - \\
\hline $28 / 1$ & humerus & s & $\mathrm{SD}=33.0 ; \mathrm{Bd}=81.1 ; \mathrm{BT}=71.8$ & - \\
\hline $24 / 4$ & radius & s & $\mathrm{Bp}=81.4 ; \mathrm{BFp}=73.3$ & - \\
\hline $24 / 10$ & ulna & s & $\mathrm{SDO}=54.8 ; \mathrm{DPA}=64.0 ; \mathrm{LO}=41.7$ & - \\
\hline $23 / 1$ & tibia & s & $\mathrm{Bd}=55.0 ; \mathrm{Dd}=40.6$ & - \\
\hline $16 / 1$ & talus & s & $\mathrm{GLI}=59.5 ; \mathrm{GLm}=53.8 ; \mathrm{Bd}=38.7 ; \mathrm{DI}=32.9$ & - \\
\hline $28 / 19$ & talus & d & $\mathrm{GLI}=66.0 ; \mathrm{GLm}=59.4 ; \mathrm{Bd}=38.7 ; \mathrm{DI}=43.4 ; \mathrm{Dm}=37.8$ & - \\
\hline $28 / 20$ & talus & $\mathrm{d}$ & $\mathrm{GLI}=55.3 ; \mathrm{GLm}=50.5 ; \mathrm{Bd}=34.4 ; \mathrm{DI}=31.6 ; \mathrm{Dm}=31.5$ & - \\
\hline $23 / 5$ & talus & s & $\mathrm{GLI}=67.2 ; \mathrm{GLm}=60.3 ; \mathrm{Bd}=44.9 ; \mathrm{DI}=37.3 ; \mathrm{Dm}=37.6$ & - \\
\hline $19 / 6$ & metacarpus & $d$ & $\mathrm{GL}=183.0 ; \mathrm{Bp}=52.3 ; \mathrm{SD}=29.8 ; \mathrm{Bd}=52.5$ & $\mathrm{~m}$ \\
\hline $19 / 7$ & metacarpus & $\mathrm{d}$ & $\mathrm{Bp}=50.5 ; \mathrm{SD}=28.1$ & - \\
\hline $24 / 9$ & metacarpus & d & $\mathrm{Bp}=48.6 ; \mathrm{SD}=26.6$ & - \\
\hline $29 / 4$ & metacarpus & $\mathrm{s}$ & $S D=29.2$ & - \\
\hline $23 / 3$ & metacarpus & $\mathrm{d}$ & $\mathrm{Bd}=55.8$ & - \\
\hline $23 / 4$ & metacarpus & s & $\mathrm{Bd}=61.2$ & - \\
\hline $32 / 1$ & metacarpus & $\mathrm{d}$ & $\mathrm{GL}=183.7 ; \mathrm{Bp}=52.1 ; \mathrm{SD}=25.8 ; \mathrm{Bd}=51.5$ & f \\
\hline $16 / 2$ & metatarsus & s & $S D=23.8$ & - \\
\hline $12 / 1$ & metatarsus & $\mathrm{d}$ & $\mathrm{GL}=211.6 ; \mathrm{Bp}=39.6 ; \mathrm{SD}=20.5 ; \mathrm{Bd}=45.6$ & $f$ \\
\hline $24 / 8$ & metatarsus & $\mathrm{s}$ & $\mathrm{Bp}=38.0 ; \mathrm{SD}=24.1$ & - \\
\hline $22 / 9$ & metatarsus & d & $\mathrm{GL}=205.1 ; \mathrm{SD}=22.4 ; \mathrm{Bd}=47.8$ & $f$ \\
\hline $22 / 10$ & metatarsus & $\mathrm{s}$ & $\mathrm{GL}=206.1 ; \mathrm{Bp}=45.7 ; \mathrm{SD}=26.3$ & $\mathrm{~m}$ \\
\hline $6 / 1$ & phalanx 1, anterior & $\mathrm{n}$ & GLpe $=41.1 ; B p=30.8 ; S D=24.7 ; B d=25.1$ & - \\
\hline $17 / 6$ & phalanx 1, posterior & $\mathrm{n}$ & GLpe $=48.5 ; B p=24.8 ; S D=20.6 ; B d=23.4$ & - \\
\hline $24 / 18$ & phalanx 1 , posterior & $\mathrm{n}$ & $\mathrm{GLpe}=52.6 ; \mathrm{Bp}=25.9 ; \mathrm{SD}=22.4 ; \mathrm{Bd}=23.9$ & - \\
\hline $8 / 1$ & phalanx 3 & $\mathrm{n}$ & $\mathrm{DLS}=71.1 ; \mathrm{Ld}=56.5 ; \mathrm{MBS}=22,8$ & - \\
\hline $14 / 2$ & phalanx 3 & $\mathrm{n}$ & DLS $=65.9 ; \mathrm{Ld}=45.1 ; \mathrm{MBS}=23.7^{*}$ deformed by pathology & - \\
\hline $12 / 7$ & phalanx 3 & $\mathrm{n}$ & $M B S=22.4$ & - \\
\hline \multicolumn{5}{|c|}{ Pig (Sus domesticus) } \\
\hline $16 / 9$ & maxilla & $\mathrm{d}$ & $M 30=27.5 ; M 31=17.4$ & - \\
\hline $24 / 2$ & mandibula & $\mathrm{s}$ & $M 10(L)=29.6 ; M 10(B)=14.1$ & - \\
\hline $22 / 7$ & mandibula & s & $M 10(L)=25.4 ; M 10(B)=14.1$ & - \\
\hline $30 / 1$ & pelvis & $\mathrm{d}$ & $\operatorname{LAR}=30.3$ & - \\
\hline \multicolumn{5}{|c|}{ Sheep (Ovis aries) } \\
\hline $3 / 3$ & processus cornualis & $\mathrm{n}$ & M44 = 105.1; M45 = 30.7; M46 = 30.0; M47 = 111.7 & f? \\
\hline $19 / 8$ & mandibula & s & $M 8=51.8 ; M 15 b=23.4$ & - \\
\hline $16 / 10$ & mandibula & $\mathrm{s}$ & $M 7=71.9 ; M 8=49.7 ; M 15 b=23.6$ & - \\
\hline $29 / 2$ & atlas & $s+d$ & $\mathrm{BFcr}=44.4 ; \mathrm{BFcd}=48.0$ & - \\
\hline $22 / 1$ & humerus & $\mathrm{s}$ & $\mathrm{Bd}=31.5 ; \mathrm{BT}=29.6$ & - \\
\hline $10 / 2$ & radius & $d$ & $\mathrm{Bd}=31.5 ; \mathrm{BFd}=22.2$ & - \\
\hline $23 / 9$ & ulna & s & $\mathrm{SDO}=24.9 ; \mathrm{DPA}=29.6 ; \mathrm{LO}=23.1$ & $\mathrm{~m} ?$ \\
\hline
\end{tabular}


Tab. A7. Continuation.

\begin{tabular}{|c|c|c|c|c|}
\hline Specimen & Skeletal element & Side & Measurements after A. von den Driesch (1976) & Sex \\
\hline \multicolumn{5}{|c|}{ Caprines (Ovis/Capra) } \\
\hline $26 / 1$ & mandibula & d & $M 7=74.0 ; M 8=47.0 ; M 9=26,0 ; M 11=8.4 ; M 15 a=41.0 ; M 15 b=24.9 ; M 15 c=17.1$ & - \\
\hline $26 / 2$ & mandibula & $\mathrm{d}$ & $M 7=74.4 ; M 8=51.8 ; M 9=22.1 ; M 11=8.7 ; M 15 b=24.1 ; M 15 c=19.8$ & - \\
\hline $22 / 8$ & mandibula & d & $M 7=46.2 ; M 8=46.2 ; M 9=23.2 ; M 11=8.5 ; M 15 b=22.3 ; M 15 c=21.2$ & - \\
\hline $24 / 19$ & pelvis & s & $L A=29.1$ & - \\
\hline $12 / 3$ & metatarsus & d & $\mathrm{Bp}=21.5 ; \mathrm{SD}=13.4$ & - \\
\hline $24 / 5$ & metatarsus & $\mathrm{s}$ & $S D=13.4$ & - \\
\hline $24 / 6$ & metacarpus & $\mathrm{s}$ & $S D=15.5$ & - \\
\hline \multicolumn{5}{|c|}{ Horse (Equus caballus) } \\
\hline $11 / 2$ & scapula & $\mathrm{s}$ & $\mathrm{SLC}=66.8 ; \mathrm{GLP}=94.1 ; \mathrm{LG}=55.9 ; \mathrm{BG}=50.4$ & $\mathrm{~m} ?$ \\
\hline \multicolumn{5}{|c|}{ Dog (Canis familiaris) } \\
\hline $9 / 4$ & radius & $\mathrm{s}$ & $S D=10.0 ; B d=21.4 ; B F d=17.7$ & - \\
\hline $9 / 6$ & metacarpus 5 & s & $\mathrm{GL}=52.0 ; \mathrm{Bd}=9.5$ & - \\
\hline
\end{tabular}

\section{LITERATURE}

Albarella 2002 - U. Albarella: 'Size matters': how and why biometry is still important in zooarchaeology. In: K. Dobney/T. O'Connor (eds.): Bones and the Man: Studies in Honour of Don Brothwell. Oxford 2002, 51-62.

Albarella/Johnstone/Vickers 2008 - U. Albarella/C. Johnstone/K. Wickers: The development of animal husbandry from the Late Iron Age to the end of the Roman period: a case study from South-east Britain. Journal of Archaeological Science 35, 2008, 1828-1848.

Ambros 1970 - C. Ambros: K včasnej histórii chovu kury domácej na Slovensku. Agrikultúra 9, 1970, 7-23.

Ambros et al. 2011 - C. Ambros/Z. Miklíková/M. Fabiš: Paleopatologické nálezy na skeletoch zvierat. In: M. Vondráková/B. Matejovičová/B. Kolena/ C. Ambros/Z. Miklíková/M. Fabiš/M. Martiniaková/M. Bauerová/M. Bauer/R. Omelka/L. Luptáková: Paleopatologické nálezy z vybraných archeologických výskumov na Slovensku. Nitra 2011, 143-201.

Armitage/Clutton-Brock 1976 - P. L. Armitage/J. Clutton-Brock: A system for classification and description of the horn cores of cattle from archaeological sites. Journal of Archaeological Science 3, 1976, 329-348.

Atici et al. 2013 - L. Atici/S. W. Kansa/J. S. E. Lev-Tov/ E. Kansa: Other People's Data: A Demonstration of the Imperative of Publishing Primary Data. Journal of Archaeological Method and Theory 20/4, 2013, 663-681.

Baker/Brothwell 1980 - J. R. Baker/D. R. Brothwell: Animal Diseases in Archaeology. London 1980.

Bartík/Farkaš/Turčan 1995 - J. Bartík/Z. Farkaš/V. Turčan: Biely Kostol. In: M. Ruttkay (ed.): Archeológia a ropa. Nitra 1995, 22, 23.

Bartík et al. 1995 - J. Bartík/Z. Farkaš/K. Prášek/V. Turčan: Výsledky výskumov Archeologického múzea SNM na trase ropovodu. AVANS 1993, 1995, 21, 22.
Bartosiewicz 1993 - L. Bartosiewicz: Early Medieval Archaeozoology in Eastern Europe. In: H. Friesinger/F. Daim/ E. Kanelutti/O.Cichocki (Hrsg.): Bioarchäologie und Frühgeschichtsforschung. Berichte des Symposions der Kommission für Frühmittelalterforschung, 13.-15. November 1990, Stift Zwettl, Niederösterreich. Wien 1993, 123-131.

Bartosiewicz 1999 - L. Bartosiewicz: A systematic review of astragalus finds from archaeological sites. Antaeus 24, 1999, 37-44.

Bartosiewicz 2013 - L. Bartosiewicz: Shuffling Nags, Lame Ducks. The Archaeology of Animal Disease. Oxford 2013.

Bartosiewicz et al. 1997 - L. Bartosiewicz/W. van Neer/ A. Lentacker/M. Fabis: Draught Cattle: their Osteological Identification and History. Annals of Scientific Zoology 281. Tervuren 1997.

Bartosiewicz/Vaughan/Tóth 2013 - L. Bartosiewicz/M. Vaughan/Zs. Tóth: Roman period evidence for a special form of perimortem trauma in large livestock. Archeometriai Mühely 10, 2013, 301-305.

Bazovský 2010 - I. Bazovský: Depot z doby rímskej z Dunajskej Lužnej. In: Beljak/Březinová/Varsik 2010, 13-23.

Behrensmeyer 1978 - A. K. Behrensmeyer: Taphonomic and ecologic information from the bone weathering. Paleobiology 4/2, 1978, 150-162.

Beljak/Březinová/Varsik 2010 - J. Beljak/G. Březinová/ V. Varsik (eds.): Archeológia barbarov 2009. Hospodárstvo Germánov. Sídliskové a ekonomické štruktúry od neskorej doby laténskej po včasný stredovek. Archeologica Slovaca Monographiae. Communicationes 10. Nitra 2010.

Beljak 2010 - J. Beljak: Germánske osídlenie v Štúrove a na dolnom Pohroní v staršej dobe rímskej. Zborník SNM 104. Archeológia 20, 2010, 141-173.

Benecke 1994 - R. Benecke: Archäozoologische Studien zur Entwicklung der Haustierhaltung in Mitteleuropa und 
Sudskandinavien von den Anfängen bis zum ausgehenden Mittelalter. Schriften zur Ur- und Frühgeschichte 46. Berlin 1994.

Bielichová 2017 - Z. Bielichová: Archaeofaunal remains from the Roman period settlement pit at Trnava-Horné pole, southwestern Slovakia. Acta Rerum Naturalium Musei Nationalis Slovaci 63, 2017, 111-134.

Bielichová/Ambros, forthcoming - Z. Bielichová/C. Ambros: Animal Bones from the Late Antique Quadi Residence in Cífer-Pác. Zvieracie kosti z neskoroantickej kvádskej rezidencie v Cíferi-Páci. In: V. Varsik/T. Kolník: Neskoroantická kvádska rezidencia v Cíferi-Páci. Trnava - Nitra, forthcoming.

Binford 1981 - L. R. Binford: Bones. Ancient Men and Modern Myths. New York 1981.

Birtalan 2003 - Á. Birtalan: Ritualistic Use of Livestock Bones in the Mongolian Belief system and Customs. In: A. Sárkozi/A. Rákos (eds.): Altaica Budapestinensia MMII. Proceedings of the $45^{\text {th }}$ Permanent International Altaistic Conference (PIAC) held in Budapest, Hungary in $23^{\text {rd }}-28^{\text {th }}$ June 2002 . Budapest 2003, 34-62.

Bíró et al. 2012 - M. T. Bíró/A. Choyke/L. Vass/Á. Vecsey: Aquincumi csonttárgyak. Bone objects in Aquincum. Budapest 2012.

Bökönyi 1974 - S. Bökönyi: History of Domestic Mammals in Central and Eastern Europe. Budapest 1974.

Bökönyi 1984 -S. Bökönyi: Animal Husbandry and Hunting in Tác-Gorsium. Budapest 1984.

Březinová et al. 2003 - G. Březinová a kolektív: Nitra-Chrenová. Archeologický výskum na plochách stavenísk Shell a Baumax. Katalóg. Archaeologica Slovaca Monographiae. Catalogi 9. Nitra 2003.

Buko 1990 - A. Buko: Ceramika wczesnopolska. Wprowadzenie do badań. Wroclaw 1990.

Calkin 1960 - V. I. Calkin: Izmencsivoszty metapodii u ce znacsenyje dlja izucsenyja krupnogo rogato szkota drevnosztyi (Metapodalia variation and its significance for the study ancient horned cattle). Biulleten Moskovskovo Obshchestva Iszpytatelei Prirodi. Otdel biologicheski 65, 1960, 109-126.

Čejka/Hajnalová 2000 - T. Čejka/M. Hajnalová: Reconstruction of environment in the surroundings areas of Komárno in the Roman period on the basis of the analysis of plant macroremains and molluscan thanatocenoses. Archeologické rozhledy 52, 2000, 316-329.

Davis et al. 2012 - S. J. M. Davis/E. M. Svensson/U. Albarella/C. Detry/A. Götherström/A. E. Pires/C. Ginja: Molecular and osteometric sexing of cattle metacarpals: a case study from $15^{\text {th }}$ century AD Beja, Portugal. Journal of Archaeological Science 39, 2012, 1445-1454.

Driesch 1976 - A. von den Driesch: A guide to the measurement of animal bones from archaeological sites. Peabody Museum bulletins 1. Harvard 1976.

Elschek 2017 - K. Elschek: Bratislava-Dúbravka im 1. bis 4. Jahrhundert n. Chr. germanischer Fürstensitz mit römischen Bauten und die germanische Besiedlung. Archeologica Slovaca Monographiae. Studia 29. Nitra 2017.

Fabiš 2003 - M. Fabiš: Archeozoologická analýza (19962000). In: Březinová et al. 2003, 99-131.

Fabiš 2005 - M. Fabiš: Pathological alterations of cattle skeletons - evidence for the draught exploitation of animals? In: J. Davies/M. Fabiš/I. Mainland/M. Richards/R. Thomas (eds.): Diet and Health in Past Animal Populations: Current Research and Future Directions. Oxford 2005, 58-62.

Fabiš/Bielichová 2014 - M. Fabiš/Z. Bielichová: Úvodná štúdia k archeozoológii vo Vel'kom Mederi. Študijné zvesti AÚ SAV 56, 2014, 169-182.

Gentry/Clutton-Brock/Groves 2004 - A. Gentry/J. Clutton-Brock/C. P. Groves: The naming of wild animal species and their domestic derivates. Journal of Archaeological Science 31, 2004, 645-651.

Gostenčnik 2010 - K. Gostenčnik: Ribs as a raw material in Roman bone artefacts from Virunum (southern Austria). In: A. Legrand-Pineau/I. Sidera (eds.): Ancient and Modern Bone Artefacts from America to Russia. Cultural, technological and functional signature. BAR International Series 2136. Oxford 2010, 149-157.

Greenfield 1988 - H. J. Greenfield: Bone Consumption by Pigs in a Contemporary Serbian Village: Implications for the Interpretation of Prehistoric Faunal Assemblages. Journal of Field Archaeology 15, 1988, 473-479.

Habermehl 1975 - K.-H. Habermehl: Alterbestimmung bei Haus- und Labortieren. Berlin - Hamburg 1975.

Habermehl 1985 - K.-H. Habermehl: Die Alterbestimmung bei Wild- und Pelztieren. Berlin - Hamburg 1985.

Hajnalová/Rajtár 2009-M. Hajnalová/J. Rajtár: Supply and subsistence: the Roman Fort at Iža. In: W. S. Hanson (ed.): The Army and Frontiers of Rome. Papers offered to David Breeze on the occasion of his sixty-fifth birthdays and his retirement from Historic Scotland. Journal of Roman Archaeology. Supplementary series 74. Porthsmouth 2009, 194-208.

Hajnalová/Varsik 2010 - M. Hajnalová/V. Varsik: Kvádske rol’níctvo na Slovensku z pohladu archeológie a archeobotaniky. In: Beljak/Březinová/Varsik 2010, 181-224.

Hajnalová/Varsik 2015 - M. Hajnalová/V. Varsik: Archäologische und botanische Untersuchungen in der kaiserzeitlichen Siedlung von Vel'ký Meder (SW-Slowakei). In: H. Friesinger/A. Stuppner (eds.): Mensch und Umwelt - Ökoarchäologische Probleme in der Frühgeschichte. Wien 2015, 109-136.

Hajnalová et al. 2018 - M. Hajnalová/Z. Bielichová/ J. Rajtár/D. Krčová/T. Čejka/Z. Šustek/J. Mihályiová: A Roman Structure from Hurbanovo, SW Slovakia: Multiproxy Investigation of Unique Waterlogged Deposit. Natural Sciences in Archaeology 9, 2018, 43-69.

Hensel 2004 - K. Hensel: Finds of capital Wels catfish Silurus glanis (Actinopterygii: Siluridae) in excavations of a Roman military fort in Southern Slovakia. Biologia 59 (Supplementum 15), 2004, 191-203.

Hrnčiarik 2014 - E. Hrnčiarik: Belege der germanischen handwerklichen Tätigkeit in der Slowakei. Anodos 11, 2014, 149-157.

Hrnčiarik 2015 - E. Hrnčiarik: Rímske a germánske výrobky $z$ kosti, parohoviny a slonoviny z auxiliárneho kastela v Iži $v$ kontexte severopanónskej hraničnej zóny. Trnava 2015.

Hrnčiarik 2017 - E. Hrnčiarik: Bone and antler artefacts from the Roman fort at Ǐ̌a. Archaeologica Slovaca Monographiae. Fontes 23. Nitra - Trnava - Komárom 2017. 
Hrudka/Popesko/Komárek 1962 - F. Hrudka/P. Popesko/ V. Komárek: Základy morfológie hospodárskych zvierat. Bratislava 1962.

Chaix/Méniel 1996 - L. Chaix/P. Méniel: Éléments d'archéozoologie. Paris 1996.

Choyke 2003 - A. M. Choyke: Animals and Roman Lifeways in Aquincum. Aquincum Nostrum 11/2, 2003, 210-232.

Jin/Shipman 2009 - J. J. H. Jin/P. Shipman: Documenting natural wear on antlers: A first step in identifying use-wear on purposed antler tools. Quarternary International 211, 2010, 91-102.

King 2001 - A. C. King: The Romanization of diet in the western Empire: comparative archaeozoological studies. In: S. Keay/N. Terrenato (eds): Italy and the West. Comparative Issues in Romanization. Oxford 2001, 210-223.

Kolda 1936 - J. Kolda: Srovnávací anatomie zvírat domácích se zřetelem $k$ anatomii člověka. Brno 1936.

Kolník 1962 - T. Kolník: Nové sídliskové nálezy z doby rímskej na Slovensku. Archeologické rozhledy 14, 1962, 344-397.

Kolník 1971 - T. Kolník: Prehl’ad a stav bádania o dobe rímskej a st’ahovaní národov. Slovenská archeológia 19, 1971, 499-558.

Kolník 1975 - T. Kolník: Výskum v Cíferi-Páci v roku 1974. AVANS 1974, 1975, 58-61.

Kolník 2010 - T. Kolník: Stráže-Krakovany a Ostrovany/ Osztrópataka. Poznámky k novým súvislostiam a nálezom z hrobov germánskej elity. In: Beljak/Březinová/Varsik 2010, 615-638.

Kolník/Varsik/Vladár 2007 - T. Kolník/V. Varsik/J. Vladár: Branč. Germánska osada z 2. až 4. storočia. Eine germanische Siedlung vom 2. bis zum 4. Jahrhundert. Nitra 2007.

Komárek/Štěrba/Fejfar 2001 - V. Komárek/O. Štěrba/ O. Fejfar: Anatomie a embryologie volně žijících přežvíkavcu․ Praha 2001.

Kraskovská 1990 - L'. Kraskovská: Náleziská z doby rímskej v Bratislave-Rusovciach. Zborník SNM 84. História 30, 1990, 17-29.

Kunst 2002 - G. K. Kunst: Die Tierreste aus Mautern a. d. Donau-Favianis. Grabung Frauenhofgasse 1996. In: S. Groh/H. Sedlmayer (eds.): Forschungen im Kastell Mautern-Favianis. Die Grabungen der Jahre 1996 und 1997. Der Römische Limes in Österreich 42. Wien 2002, 469-581.

Kuzma/Bielich 2009 - I. Kuzma/M. Bielich: Výskum vo Vel'kom Záluží. AVANS 2008, 2011, 161.

Kuzmová/Rajtár 1986a - K. Kuzmová/J. Rajtár: Anfänge des Römerlagers in Iža. Archeologické rozhledy 38, 1986, 358-377, 459-462.

Kuzmová/Rajtár 1986b - K. Kuzmová/J. Rajtár: Bisherige Erkenntnisse zur Befestigung des Römerkastells in Iža. Slovenská archeológia 34, 1986, 185-224.

Kuzmová/Rajtár 1996 - K. Kuzmová/J. Rajtár (eds.): Gerulata I. Nitra 1996.

Kyselý 2004 - R. Kyselý: Kvantifikační metody v archeozoologii. Archeologické rozhledy 56, 2004, 279-296.

Kyselý 2016 - R. Kyselý: The size of domestic cattle, sheep, goats and pigs in the Czech Neolithic and Eneolithic Periods: Temporal variations and their causes. Archaeofauna 25, 2016, 33-78.
Lapham 2005 - H. A. Lapham: Hunting for hides. Deerskins, Status, and Cultural Change in the Protohistoric Appalachians. Tuscaloosa 2005.

Lehmkuhl 1984 - U. Lehmkuhl: Archäozoologische Betrachtung uber Astragalusfunde aus Brandgräbern der römische Kaiserzeit in Mecklenburg und ihr Brauchtum. Bodendenkmalpflege in Mecklenburg-Vorpommern 32, 1984, 241-251.

Luff 1994 - R. M. Luff: The Conundrum of Castration in the Archaeological Record: an Interpretation of Roman Cattle Horn-cores from Chelmsford, Essex. International Journal of Osteoarchaeology 4, 1994, 171-192.

Lyman 1994 - R. L. Lyman: Vertebrate taphonomy. Cambridge 1994.

Lyublyanovics 2010 - K. Lyublyanovics: Animal Keeping and Roman Colonization in the Province of Panonia Inferior, Western Hungary. In: D. Campana/ P. Crabtree/S. D. deFrance/J. Lev-Tov/A. M. Choyke (eds.): Anthropological Approaches to Zooarchaeology. Colonialism, Complexity and Animal Transformations. Oxford - Oakville 2010, 182-193.

Matolcsi 1970 - J. Matolcsi: Erforschung der Körpergröße des Rindes auf Grund von ungarischem Knochenmaterial. Zeitschrift für Tierzüchte und Züchtungsbiologie $87,1970,89-137$.

Miklíková 2003a-Z. Miklíková: Zvieracie zvyšky z doby rímskej v Beluši. AVANS 2002, 2003, 92, 93.

Miklíková 2008 - Z. Miklíková: Skeletal alternations of animal remains from the early medieval settlement of Bajč, south-west Slovakia. In: Z. Miklíková/R. Thomas (eds.): Current Research in Animal Palaeopathology. Proceedings of the Second ICAZ Animal Palaeopathology Working Group Conference. BAR Interanional Series 1844. Oxford 2008, 63-73.

Miklíková 2010 -Z. Miklíková: Archeozoologická analýza predmetov z depotu v Dunajskej Lužnej. In: Beljak/ Březinová/Varsik 2010, 27-31.

Meier 2013 - J. Meier: More than Fun and Games? An experimental Study of Worked Bone Astragali from Two Middle Bronze Age Hungarian Sites. In: A. Choyke/ S. O'Connor (eds.): From These Bare Bones. Raw materials and the study of worked osseous objects. Oxford 2013, 166-173.

Novotný 1984 - B. Novotný: Chata z doby rímskej v Želiezovciach (okr. Levice). In: E. Studeníková/L. Zachar (zost.): Zborník prác L'. Kraskovskej (k životnému jubileu). Bratislava 1984, 107-117.

Ožd’áni 1984 - O. Oždáni: Záchranný výskum v Malej nad Hronom. AVANS 1983, 1984, 171, 172.

Pavúk 1977 - J. Pavúk: Sídlisko z doby bronzovej a doby rímskej v Trnave-Modranke. AVANS 1976, 1977, 224, 225.

Peške 1985 - L. Peške: Osteologické nálezy kultury zvoncovitých pohárů $\mathrm{z}$ Holubic a poznámky k zápřahu skotu v eneolitu. Archeologické rozhledy 37, 1985, 428-440.

Peške 1994 - L. Peške: Osteologické nálezy z Mlékojed o. Mělník ze starší doby římské. Archaeologické rozhledy 46, 1994, 306-318.

Pieta 1993 - K. Pieta: Osídlenie z doby rímskej a st’ahovania národov v Nitre. In: K. Pieta (zost.): Nitra. Príspevky k najstarším dejinám mesta. Nitra 1993, 74-90. 
Pieta/Ruttkay 1997 - K. Pieta/M. Ruttkay: Germanische Siedlung aus dem 4. und 5. Jh. in Nitra-Párovské háje und Probleme der Siedlungskontinuität. In: J. Tejral/ H. Friesinger/M. Kazanski (Hrsg.): Neue Beiträge zur Erforschung der Spätantike im mittleren Donauraum. Spisy Archeologického ústavu AV ČR Brno 8. Brno 1997, 145-163.

Popesko et al. 1974 - P. Popesko et al.: Nomina Anatomica Veterinaria. Bratislava 1974.

Pucher 1999 - E. Pucher: Archäozoologische Untersuchungen am Tierknochenmaterial der keltischen Gewerbesiedlung im Ramsautal auf dem Dürrnberg (Salzburg). DürrnbergForschungen 2. Rahden/Westf 1999.

Pucher 2006 - E. Pucher: Zwei Römische Ochsenskellette aus der Villa Rustica von Nickelsdorf (Österreich). In: U. Tecchiati/B. Sala (Hrsg.): Archäozoologische Studien zu Ehren von Alfredo Riedel. Bolzano 2006, 253-268.

Pucher 2016 - E. Pucher: Die Tierknochenfundkomplex eines germanischen Dorf im römischen Machtbereich: Bruckneudorf. Fundberichte Österreichs 55, 2016, 235-422.

Pucher/Saliari/Ramsl 2015 - E. Pucher/K. Saliari/P. Ramsl: Römische Haustiere eines Latènezeitlichen Hausherrn in Vindobona (Wien)? Beiträge zur Archäozoologie und Prähistorische Anthropologie 10, 2015, 71-78.

Rajtár 1992 - J. Rajtár: Das Holz-Erde-Lager aus der Zeit der Markomannenkriege in Iža. In: K. Godłowski/ R. Madyda-Legutko (red.): Probleme der relativen und absoluten Chronologie ab Latènezeit bis zum Frühmittelalter. Kraków 1992, 149-170.

Reitz/Wing 1999 - E. J. Reitz/E. S. Wing: Zooarchaeology. Cambridge 1999.

Riedel 1996 - A. Riedel: Die Tierknochenfunde einer germanischen Siedlung an der Thaya bei Bernhardstahl im nordöstlichen Niederösterreich. Annalen Naturhistorischen Museums in Wien 97/A, 1996, 55-144.

Riedel 2004 - A. Riedel: Tierknochen aus der römischen Villa rustika von Nickelsdorf in Burgenland (Österreich). Annalen des Naturhistorischen Museums in Wien 106/A, 2004, 449-539.

Rixson 1988 - D. Rixson: Butchery evidence on animal bones. Circaea 6, 1988, 49-62.

Rogatko 1994 - J. Rogatko: O niektórych kategoriach wyrobów koscianych i rogowych w obrębie kultury Przeworskiej. In: J. Gurba/Akokowski (red.): Kultura Przeworska 1. Lublin 1994, 343-361.

Ruttkayová/Ruttkay 2015 -J. Ruttkayová/M. Ruttkay: Horné Požitavie. Svedectvo archeológie. Archaeologica Slovaca Monographiae. Varia 5. Nitra 2015.

Seetah $2006 b-$ K. Seetah: Multidisciplinary approach to Romano-British cattle butchery. In: M. Maltby (ed.): Integrating Zooarchaeology. Proceedings of the $9^{\text {th }}$ ICAZ Conference. Oxbow 2006, 111-118.

Seetah 2007 - K. Seetah: The importance of cut placement and implement signatures to butchery interpretation. ICAZ Essay Prize Submission. http://alexandriaarchive. org/bonecommons/archive/files/archivefiles_downloadseetah_textimages_204_7cd9b26908.pdf [cit. 20-04-2017].

Schmid 1972 - E. Schmid: Atlas of animal bones. Amsterdam - London - New York 1972.
Silver 1969 - I. A. Silver: The ageing of domestic animals. In: D. R. Brothwell/E. S. Higgs (eds.): Science in archaeology. A survey of progress and research. New York $1969,250-268$.

Sidéra/Vornicu 2016 - I. Sidéra/A. Vornicu: The Archaeology of Games. Playing with knucklebones in the Early Chalcolithic of the Balkans. In: K. Bacvarov/ R. Gleser (eds.): Southeast Europe and Anatolia in prehistory. Essays in honour of Vassil Nikolov on his $65^{\text {th }}$ anniversary. Universitätforschungen zur Prähistorischen Archeologie 293. Bonn 2016, 379-388.

Strapák et al. 2013 - P. Strapák/V. Tančin/K. Vavrišínová/ P. Grafenau/J. Bulla/P. Chrenek/M. Šimko/M. Juráček/ P. Polák/Š. Ryba/P. Juhás/J. Huba/Z. Krupová: Chov hovädzieho dobytka. Nitra 2013.

Šefčáková 2011 - A. Šefčáková: Archeozoologická analýza nálezov z germánskych sídlisk na východnom okraji Bratislavy. In: Varsik 2011, 385-404.

Švecová 2001 - R. Švecová: Nálezy astragalov na Pohansku pri Břeclavi. Sborník prací Filozofické fakulty Brněnské univerzity M 6, 2001, 149-165.

Tacitus, Germánia - P. C. Tacitus: Agricola, Anály, Germánia, Histórie. Preložili J. Žigo/M. Paulinyová/J. Rovenská. Bratislava 1980.

Trantalidou/Kavoura 2008 - K. Trantalidou/I. Kavoura: Astragali in Caves. The Contribution of the Archaeozoology in the Understanding of Some Ancient Greek Cult Practices. Anodos 6-7, 2008, 459-473.

Turčan 1995 - V. Turčan: Most pri Bratislave. In: M. Ruttkay (ed.): Archeológia a ropa. Nitra 1995, 4-5.

Turčan 1996 - V. Turčan: Germánske objekty medzi Trnavou a Bohdanovcami. Zborník SNM 90. Archeológia 6, 1996, 107-120.

Uerpmann 1973 - H. P. Uerpmann: Animal bone finds and economic archaeology: a critical study of 'osteoarchaeological' method. World Archaeology 4, 1973, 307-322.

Val/Mallye 2011 - A. Val/J.-B. Mallye: Small Carnivore Skinning by Professionals: Skeletal Modifications and Implication for the European Upper Palaeolithic. Journal of Taphonomy 9, 2011, 221-243.

Varsik 2003b - V. Varsik: Vel'ký Meder und Bratislava-Trnávka: zwei germanische Siedlungen im Vorfeld des pannonischen Limes (Befunde und Chronologie in Übersicht. Anodos 3, 2003, 153-196.

Varsik 2003c - V. Varsik: Záchranný výskum v Jakubove. AVANS 2002, 2003, 157-159.

Varsik 2004 - V. Varsik: Zur Entwiclung der Quadischen Siedlung von Vel'ký Meder (SW Slowakei). Študijné zvesti AÜ SAV 36, 2004, 257-275.

Varsik 2011 - V. Varsik: Germánske osídlenie na východnom predpolí Bratislavy. Sídliská z doby rímskej v Bartislave-Trnávke a v okolí. Archaeologica Slovaca Monographiae. Fontes 18. Nitra 2011.

Varsik/Kolník 2013 - V. Varsik/T. Kolník: Cífer-Pác-Neue Erkenntnisse zur spätantiken quadischen Elitenresidenz. In: M. Hardt/O. Heinrich-Tamáska (Hrsg.): Macht des Goldes, Gold der Macht. Herrschafts- und Jenseitsrepräsentation zwischen Antike und Frühmittelalter im mittleren Donauraum. Forschungen zu Spätantike und Mittelalter 2. Weinstadt 2013, 71-90. 
Varsik/Kolník, forthcoming - V. Varsik/T. Kolník: Neskoroantická kvádska rezidencia v Cíferi-Páci. Trnava - Nitra, forthcoming.

Vigne 1991 - J.-D. Vigne: The meat and offal weight (MOW) method and the relative proportion of ovicaprines in some ancient meat diets of the north-western. Mediterranean Rivista di Studi Liguri 57, 1991, 21-47.

Vitezović 2014 - S. Vitezović: Pavlovac-kovačke Njive: preliminarnij izveštaj analize. In: D. Antonović/ S. Golubović/V. Bikić (ur.): Archeologia u Srbiji koštanej industrije. Projekti Archeološkog instituta u 2012. Beograd 2014, 16-19.

Vitezović 2016 - S. Vitezović: Methodology for studying prehistoric osseous industries. Beograd 2016.

Vörös 2002 - I. Vörös: Farm and hunted animals from the Roman Imperial period in Hungary (a sketch). Specimina Nova Universitatis Quinqueeclesiensis 16, 2002, 227-242.

Zeman 2001 - T. Zeman: Germánská kostěná a parohová industrie doby římské ve středoevropském Barbariku. Sborník prací Filozofické fakulty Brněnské univerzity M 6. Brno 2001, 107-147.

Žaár/Poláková/Bielich 2009 - O. Žaár/Z. Poláková/ M. Bielich: Nálezy z mladšej doby rímskej z Vel'kého Zálužia. Zborník SNM 103. Archeológia 19, 2009, 295-316.

\section{Unpublished Sources}

Ambros 1977a-C. Ambros: Cífer-Pác, poloha Nad mlynom. Research report 8141/77. Institute of Archaeology of SAS. Nitra 1977. Unpublished.

Ambros 1977b-C. Ambros: Cífer-Pác, poloha Nad mlynom. Research report (osteometric data). Institute of Archaeology of SAS. Nitra 1977. Unpublished.

Ambros 1984 - C. Ambros: Štúrovo-Vojenské cvičisko. Research report 10780/84. Institute of Archaeology of SAS. Nitra 1984. Unpublished.

Ambros 1986 - C. Ambros: Iža-Leányvár. Research report 11619/86. Institute of Archaeology of SAS. Nitra 1986. Unpublished.

Manuscript accepted 4. 5. 2019

Translated by author
Ambros 1991 - C. Ambros: Tierreste aus der römischen Station in Iža-Leányvár Nitra 1991. Unpublished manuscript.

Beljak 2008 - J. Beljak: Východná enkláva Kvádov (osada v Štúrove v kontexte germánskeho osídlenia na Pohroní a Poiplí). Dissertation thesis. Institute of Archaeology of SAS. Nitra 2008. Unpublished.

Bielich 2008 - M. Bielich: Vel'ké Zálužie, poloha Ďuriho sad. Research report 16463/08. Institute of Archaeology of SAS. Nitra 2008. Unpublished.

Fabiš 1980 - M. Fabiš: Vel’ký Meder-Vámostelek. Research report (osteometric data). Institute of Archaeology of SAS. Nitra 1980. Unpublished.

Hlavatá 2017 - J. Hlavatá: Rastlinné potraviny, ich produkcia, úprava a skladovanie v germánskom a rímsko-provinciálnom prostredí na území stredného Dunaja. Dissertation thesis. Philosophical Faculty. Comenius University. Bratislava 2017. Unpublished.

Krčová 2016 - D. Krčová: Zdroje obživy, príprava jedál a stravovacie zvyklosti germánov v strednom Podunajsku vo svetle historických a hmotných prameňov. Diploma thesis. Philosophical Faculty. Constatnine the Philosopher University. Nitra 2016. Unpublished.

Miklíková 2009 - Z. Miklíková: Vel'ké Zálužie-Ďuriho sad. Research report 16953/09. Institute of Archaeology of SAS. Nitra 2009. Unpublished.

Novotný 1966 - A. Novotný: Osteologický material domácích zvírat ze sídlišt' IX.-poč. XV. století. Diploma thesis. Faculty of Science. Charles University. Praha 1966. Unpublished.

Seetah 2006a - K. Seetah: Butchery as an Analytical Tool. A Comparative Study of the Romano-British and Medieval Periods. Dissertation thesis. Faculty of Archaeology and Anthropology. University of Cambridge. Cambridge 2006. Unpublished.

Varsik 2003a-V. Varsik: Räumliche und naturwissenschaftliche Studien zu der germanischen Siedlung der römischen Kaiserzeit in der Slowakei (Beispielfall von Vel'ký Meder). Zwischenbericht. Research report I/13. Institute of Archaeology of SAS. Nitra 2003. Unpublished.

Mgr. Zora Bielichová

Archeologický ústav SAV

Akademická 2

SK - 94921 Nitra

zora.miklikova@savba.sk 


\title{
Archeozoológia sídliska z obdobia mladšej doby rímskej vo Vel'kom Záluží v kontexte regionálnych dát
}

\author{
Z or a Bielichová
}

\author{
SÚHRN
}

Príspevok predstavuje výsledky analýzy archeozoologického materiálu (n=321) získaného počas výskumu sídliska z mladšej doby rímskej na polohe Vel'ké Zálužie-Ďuriho sad. Lokalita sa nachádza na juhozápadnom Slovensku v okrese Nitra, približne $80 \mathrm{~km}$ severne od Dunaja (obr. 1; 4) a bola čiastočne preskúmaná v rámci krátkodobého záchranného výskumu na prelome rokov 2002/2003. Okrem ostatných druhov materiálnej kultúry sa z odkrytých objektov - čiastočne zahíbená chata, tri zásobné jamy, dve odpadové jamy, štyri hliníky a jedenást’ bližšie neurčených jám (obr. 2; 3), podarilo vyzdvihnút aj nálezy zvieracích kostí a zubov. Ich analýza naznačila, že predstavujú zmiešaný, jatočný, konzumný a remeselný odpad súvisiaci so stravovaním a pracovnými aktivitami obyvatelov osady. Druhová skladba zastúpených zvierat, hodnotená v rámci archeologického kontextu, umožňuje predpokladat', že jedným zo zdrojov obživy miestnej komunity bol chov domácich zvierat. Ich zvyšky v súbore tvoria viac ako polovicu nálezov - 64,2 \% NISP, resp. 82,8 \% MNI a 86 \% WISP. Podobne je tomu vo všetkých dosial' preskúmaných súboroch zo sídlisk doby rímskej na juhozápadnom Slovensku a stredom Dunaji (tabela 6; 8; pozri tiež Benecke 1994; Bökönyi 1974; Vörös 2002).

Výsledky NISP z Vel'kého Zálužia naznačujú, že pre mäso bol najčastejšie využívaný tur (Bos taurus) a ošípaná (Sus domesticus). Malé prežúvavce (Ovis/Capra, v súbore identifikovaná len ovca domáca, Ovis aries) a divo žijúce zvieratá (najmä jeleň lesný, Cervus elaphus) predstavovali druhý najdôležitejší zdroj mäsa. Kôň (Equus caballus) a pes (Canis familiaris) boli v súbore zastúpení minimálne, pravdepodobne kvôli inému módu využitia (napr. práca, transport a pod.). Zvyšky domácej hydiny, na germánskych lokalitách reprezentovanej hlavne druhmi kura a hus domáca, neboli vo Vel'kom Záluží identifikované. Podobne sa v súbore nenašli ani kosti mačky domácej (Felis catus) alebo osla domáceho (Equus asinus). Tieto druhy sa na území juhozápadného Slovenska po prvýkrát objavujú v súvislosti s rímskou expanziou na Dunaji (Iža, Rusovce; tabela 7).

Potvrdením NISP výsledkov je hmotnost’ nálezov (WISP). To jednoznačne poukazuje na tura ako primárneho „dodávatela“ mäsa do „kuchyne“ Germánov (61,5\%). Doplnkom bielkovinovej výživy bolo mäso a tuk ošípanej $(14,4 \%)$, malých prežúvavcov $(7,6 \%)$ a divej zveri (6,2\%). Kvantifikácia nálezov na základe minimálneho počtu jedincov (MNI) tiež indikuje, že miestne obyvatel'stvo najčastejšie porážalo ošípané (31 \%), zrejme aj vd’aka vyššej miere ich reprodukcie a azda nižšej "ceny" zvierat’a v kontexte zástupcov domácej fauny. Kultúrne preferencie alebo zvýšený dopyt po (bravčovom) mäse obyvatel'mi tejto lokality tiež nemožno vylúčit. Naše dáta svedčia o tom, že tur (24,1 \% MNI), malé prežúvavce $(17,2 \%)$ a jeleň $(17,2 \%)$ boli na sídlisku porážané v menšej miere.

Lokálne zvýšenie konzumácie bravčového na úkor hovädzieho mäsa bolo zaznamenané aj na germánskych lokalitách v okolí Bratislavy, v mladšej fáze osídlenia v 3.-4. stor. n. 1. (Šef̌ćáková 2011). Vo všeobecnosti však na väčšine územia juhozápadného Slovenska pozorujeme prevahu konzumácie hovädzieho mäsa (obr. 11). Ak však porovnáme zastúpenie vel'kostne porovnatel'ných stredne vel'kých druhov - ošípanej a ovce/kozy, preferencie bravčového alebo ovčieho/kozieho mäsa sa na niektorých sídliskách doby rímskej na sledovanom území vymykajú z všeobecného obrazu a NISP výsledkov (obr. 12). V Moste pri Bratislave a vo Vel'kom Mederi sa ukazuje, že konzumácia bravčového tu bola v porovnaní s baraním/jahňacím (kozím) nižšia. Naopak, vo Vel'kom Záluží, Nitre-Chrenovej a Štúrove sa javí konzumácia oboch druhov mäsa vyrovnaná. Pozorované rozdiely zatial' nemožno uspokojivo vysvetlit'. Nedovoluje to nízky počet nálezov z niektorých porovnávaných sídlisk i absencia citlivejšej chronológie. Ako už bolo uvedené, do úvahy zatial' pripadajú kultúrne, socioekonomické a azda aj environmentálne vplyvy. Výrazne odlišný stravovací režim je zatial' možné pozorovat iba na rímskych lokalitách z územia Slovenska - vo vojenských táboroch v Iži a Rusovciach. Tu dominuje mäso malých prežúvavcov (obr. 11; 12).

Divo žijúce zvieratá identifikované vo Vel'kom Záluží zahŕňajú dva druhy vysokej zveri - jeleňa (Cervus elaphus) a srnca (Capreolus capreolus). Ich kosti a zuby tvoria $\mathrm{v}$ analyzovanom súbore relatívne vysoký podiel (10\% NISP; $17,2 \%$ of MNI; 6,2 \% of WISP), čo poukazuje na význam loveckých aktivít v obžive obyvatelov sídliska. Určenie veku (3-4 mesiace) čiastočne zachovanej kostry mlád’ata jeleňa v jame 54 umožňuje stanovenie „loveckej udalosti“" na neskoré leto až začiatok jesene (august-september). Jeleň lesný patrí medzi najfrekventovanejšie druhy divej fauny zo sídlisk na juhozápadnom Slovensku. Popri ňom a srncoch sa lovili, príp. konzumovali aj iné vol’ne žijúce druhy - diviak, pratur, zajac, vlk, líška a bobor (tabela 7). Podobne ako pri hospodárskych zvieratách, okrem konzumovatelných produktov využívala sa ich koža, srst', kosti ako zdroj suroviny pre remeslo. Zvyšky vtákov a rýb bud' absentujú, alebo boli výnimočne identifikované, no v nízkom počte (tabela 8). 
Napriek tomuto celkovo nízkemu počtu nálezov Vel'ké Zálužie, v porovnaní so súvekými sídliskami, vykazuje najvyššie zastúpenie divých cicavcov.

Anatomická skladba kostí v súbore svedčí o prítomnosti živých jedincov, prípadne transportu/spracovania celých tiel u tura, ošípanej, ovce a azda aj jeleňa na skúmanom sídlisku. Kostra nedospelého jeleňa, do jamy 54 pravdepodobne uloženého (obr. 15), vyvoláva otázky ohladom možného držania (chovu?) živého zvierata v areáli osady. Žial', bližšie nálezové okolnosti nálezu neboli v rámci terénneho výskumu zachytené, a preto ho nemožno interpretovat’ $\mathrm{v}$ profánnom ani rituálnom kontexte. V každom prípade bolo toto mlád’a, či už živé alebo mŕtve, na sídlisku prítomné.

Porovnanie zastúpenia osvalených a neosvalených častí kostry bežne konzumovaných domácich druhov ukázalo, že zatial čo tura prevažne reprezentujú málo a stredne osvalené časti, u ošípanej prevažujú stredne a kvalitne osvalené časti tela. V jedinej preskúmanej chate dominujú fragmenty z osvalených partií, zatial' čo v odpadových jamách prevládajú najmä bezmäsité časti (v dnešnej dobe tzv. jatočný odpad; obr. 13). Podobnú anatomickú skladbu u tura, s prevažným zastúpením dolnej čeluste a metapódií a chýbaním rebier/stavcov, možno pozorovat' aj v iných súboroch $\mathrm{z}$ doby rímskej (napr. v Nitre-Chrenovej; obr. 14).

Bližšie informácie o type sídliska (sezónne/celoročne osídlené?) a socioekonomickom statuse obyvatelov (rolníci/remeselníci/vyššia vrstva?) nedovolujú, spolu s nedostatkom dát o pohlaví a veku jatočných zvierat, vyvodzovat' jednoznačné závery o chovatel'ských praktikách miestnej komunity. Výsledky však naznačujú, že i na tomto sídlisku sa s najväčšou pravdepodobnostou uplatňovali tradičné vidiecke postupy, ked' sa v stáde preferovali samice a sezónne sa zabíjali nedospelé (nadbytočné) samce. Morfológia i metrické charakteristiky končatín a rohového výbežku tura svedčia o prevahe kráv v analyzovanom odpade (tabela 9). Zachované časti čelustí ošípanej naopak poukazujú na prevahu samcov. Hovädzí dobytok bol vo Vel'kom Záluží najčastejšie zabíjaný pred dosiahnutím dospelosti, v období medzi 2. až 6. mesiacom a 2. až 4. rokom (tabela A4-A6). Inak tomu bolo napríklad na sídlisku v Nitre-Chrenovej (obr. 19). Tu bola zaznamenaná prevaha dospelých jedincov, čo M. Fabiš interpretuje v súvislosti so zameraním chovu hovädzieho dobytka na mlieko a prácu v záprahu (Fabiš 2003). Prítomnost' kastrovaných samcov tura v nálezoch z Nitry-Chrenovej, a naopak ich absencia vo Vel'kom Záluží, by mohla byt tiež dôsledkom rozdielov v exploatácii tura na menovaných lokalitách. Čo sa týka veku smrti u ostatných druhov hospodárskych zvierat, ošípané boli zabíjané v ideálnom jatočnom veku - v rozpätí 1 . a 2. roku života, zatial' čo malé prežúvavce (azda ovce) v rôznych vekových kategóriách vrátane nedospelých aj dospelých, ale starších jedincov. Je teda pravdepodobné, že ovce (kozy?) boli, podobne ako v Nitre-Chrenovej, chované primárne k produkcii vlny (srsti?) a mlieka a až sekundárne na mäso. V jarnom období alebo v prípade „nadprodukcie“ mlád’at mohli potom obyvatelia oboch osád so zvieratami v ideálnom jatočnom veku 1 až 2 rokov obchodovat', tak to interpretuje M. Fabiš $(2003,109)$. Je zaujímavé, že tak ako na sídlisku v Nitre-Chrenovej aj vo Vel'kom Záluží chýbajú jedince oviec (kôz?) v uvedenom ideálnom veku pre produkciu mäsa.

Metrické dáta v skúmanom súbore ukazujú, že germánska komunita chovala typický „,barbarský“ dobytok s malými rozmermi tela a krátkymi rohmi (typ brachyceros). Výška v kohútiku (Matolcsi 1970) sa pohybovala v rozmedzí 109,3-112,7 cm u kráv (v priemere 110,9) a 115,8-116 cm u býkov/kastrátov (v priemere 115,9). Celková priemerná výška v kohútiku bola odhadnutá na 113,7 cm, čo korešponduje s hmotnostou asi $350 \mathrm{~kg}$ (krava 333 kg; býk/kastrát $367 \mathrm{~kg}$ ). V porovnaní s doposial' získanými údajmi o vel'kosti dobytka na sídliskách doby rímskej na juhozápadnom Slovensku (v priemere $117 \mathrm{~cm}$; $382 \mathrm{~kg}$ ) boli teda jedinci z Vel'kého Zálužia menších rozmerov, čo je logické ak sa vezme do úvahy výsledok týkajúci sa pohlavia, t. j. prevahy samíc (kráv) v stáde i odpade. Iné germánske lokality, napríklad Štúrovo a Trnava-Horné pole, naopak vykazujú celkovo vyššie zastúpenie samcov a aj vyššie priemerné hodnoty výšky v kohútiku (porovnaj obr. 17; 18; tabela 10). Dodatočné vyhodnotenie rozmerov vel'kosti členkových kostí (talus/astragalus) tura zo súvekých lokalít (tabela 11) však poukazuje aj na samice z Vel'kého Zálužia, ktoré dosahujú v priemere väčšie rozmery a zapadajú do rámca stredne vel'kého typu dobytka, ktorý bol identifikovaný na germánskej lokalite Bruckneudorf v Dolnom Rakúsku (Pucher 2016) a vznikol krížením domácich "germánskych“ a dovezených „rímskych“ zvierat.

Stopy po l'udských zásahoch, ktoré boli v analyzovanom súbore zaznamenané na kostiach tura, ovce/ kozy, ošípanej a jeleňa, poukazujú na manipuláciu $\mathrm{s}$ ich telami pred a počas kuchynskej úpravy (tabela 3). Naopak, absencia rezania, sekania či rozbíjania kostí u psa a koňa zrejme ilustruje odlišný spôsob ich využívania a nenaznačujú konzumáciu ich mäsa obyvatelmi sídliska. V príspevku sú bližšie opísané i interpretované konkrétne prípady súvisiace s usmrtením (podrezanie?) a jatočným/kuchynským spracovaním tiel zvierat - oddelovanie hlavy, delenie v kĺboch, redukcia vel'kých častí na menšie porcie, extrakcia špiku a podobne (obr. 6). Charakterizovat typické postupy pre jednotlivé druhy zvierat však nebolo možné rekonštruovat' vzhl'adom na celkový nízky počet preskúmaných zvyškov. Zaujímavostou je, že v porovnaní s inými germánskymi lokalitami, kde bola frekvencia a typy ludských zásahov sledované (napr. Trnava-Horné pole - Bielichová 2017), materiál z Vel'kého Zálužia vykazuje intenzívnejšie delenie/sekanie kostí (kovovými) nástrojmi. A hoci počas archeologického výskumu lokality neboli nože s vel'kou čepelou, sekery či sekáče objavené, stopy registrované na kostiach jednoznačne dokladajú ich využívanie v kuchyni (obr. 7).

Takmer úplná absencia spálených kostí (evidujeme jediný fragment sfarbený do čierna) podporuje archeológmi vyslovenú hypotézu o bezkonfliktnom opustení sídliska jeho obyvatel'mi (Žaár/Poláková/Bielich 2009, 312). Možno predpokladat', že živočíšny odpad bol odhadzovaný do jám zámerne a nebol napríklad spalovaný. Ked’že skúmaný súbor z vel'kej časti reprezentuje potravinový odpad, možno tento výsledok tiež interpretovat' $\mathrm{v}$ rovine kuchynskej prípravy jedál. Zdá sa, že miestna kulinárska prax preferovala varenie (bez či s kostou) 
alebo pečenie/grilovanie mäsa bez kosti. Na obmedzený prístup hlodavcov k odpadu, minimálne v preskúmanej časti areálu, poukazuje absencia stôp po hryzení alebo hlodaní. Avšak kŕmenie (domácich) mäsožravcov (psov) kuchynským odpadom možno na základe častých stôp po zuboch Canidae predpokladat' (obr. 8). Ludia a psi sa zrejme najväčšou mierou pričinili o stav zachovania analyzovaných zvyškov a ich fragmentáciu (obr. 10; tabela 5).

Čast' materiálu nesie aj iný typ modifikácií, súvisiacich s remeselnými aktivitami obyvatelov sídliska. Kolekcia kostených a parohových artefaktov zahŕňa dva jednoznačné a tri otázne predmety (tabela 4; obr. 9). Surovina na ich výrobu bola čerpaná z domáceho prostredia - sídliskového odpadu (členková kost’ a rebrá tura), prípadne z jeho prírodného zázemia - okolitých lesov (parožie jeleňa). Interpretácia funkcie predmetov označených predbežne ako artefakty zostáva otázna. Paralely naznačujú spojenie s domácimi remeselnými aktivitami (odpadová surovina zo spracovania parožia jeleňa, predmety s použitím pri textilnej/keramickej výrobe) alebo hrou a veštením (ohladená členková kost’ tura). Zaujímavostou je koncentrovanie týchto nálezov v jamách 9 a 15.

Je zrejmé, že aj analýza menších súborov, pokial' je komplexná, môže významne obohatit doposial' sporé poznatky o živočíšnom hospodárstve a stravovacích zvyklostiach obyvatel'ov Slovenska v dobe rímskej. Dostupné archeozoologické analýzy z germánskych sídlisk na juhozápadnom Slovensku, ktorých výsledky boli stručne zhodnotené a využité v tomto príspevku, poskytujú dôležité doklady kontaktov barbarských germánskych kmeňov s „kultivovanou“ Rímskou ríšou. Medzi tie najpresvedčivejšie možno zaradit’ osteologické nálezy nových, na území severne od Dunaja, nepôvodných domácich druhov zvierat (napr. osol, mačka, holub). Na druhej strane, málo preukazné dáta o veku, pohlaví a morfológii $\mathrm{v}$ tom čase chovaných zvierat, stále neumožňujú skúmat’ vo väčšom meradle kontinuitu a chovatel'stvo či lovectvo v časopriestore. Väčšina záverov, uvedených alebo sumarizovaných $\mathrm{v}$ tejto práci, tak zostáva $\mathrm{v}$ rovine hypotéz. Jedine d’alšie prepracované analýzy dostatočne vel'kého počtu ručných i preplavených archeozoologických vzoriek s jasným archeologickým a chronologickým kontextom a dokumentáciou $\mathrm{v}$ teréne umožnia skúmat’ detaily socioekonomických zmien v dobe rímskej a ich možné prejavy v pol'nohospodárstve (napr. Albarella/Johnstonel Vickers 2008). Podmienkou je dobudovanie databázy výsledkov analýz kostí zvierat z doby rímskej a unifikácia metodických postupov (viac Atici et al. 2013). Primárne dáta získané počas analýzy materiálu zo sídliska vo Vel'kom Záluží sú pripojené $\mathrm{k}$ textu príspevku formou apendixu (tabela A1-A7). 